\title{
Secondary Waste Cementitious Waste Form Data Package for the Integrated Disposal Facility Performance Assessment
}

\author{
KJ Cantrell \\ JH Westsik, Jr \\ RJ Serne \\ W Um \\ AD Cozzi
}

\section{May 2016}




\title{
DISCLAIMER
}

This report was prepared as an account of work sponsored by an agency of the United States Government. Neither the United States Government nor any agency thereof, nor Battelle Memorial Institute, nor any of their employees, makes any warranty, express or implied, or assumes any legal liability or responsibility for the accuracy, completeness, or usefulness of any information, apparatus, product, or process disclosed, or represents that its use would not infringe privately owned rights. Reference herein to any specific commercial product, process, or service by trade name, trademark, manufacturer, or otherwise does not necessarily constitute or imply its endorsement, recommendation, or favoring by the United States Government or any agency thereof, or Battelle Memorial Institute. The views and opinions of authors expressed herein do not necessarily state or reflect those of the United States Government or any agency thereof.

\author{
PACIFIC NORTHWEST NATIONAL LABORATORY \\ operated by \\ BATTELLE \\ for the \\ UNITED STATES DEPARTMENT OF ENERGY \\ under Contract DE-AC05-76RL01830
}

Printed in the United States of America
Available to DOE and DOE contractors from the Office of Scientific and Technical Information,
P.O. Box 62, Oak Ridge, TN 37831-0062;
ph: (865) 576-8401
fax: (865) 576-5728
email: reports@adonis.osti.gov

Available to the public from the National Technical Information Service

5301 Shawnee Rd., Alexandria, VA 22312 ph: (800) 553-NTIS $(6847)$

email: orders@ntis.gov $<$ http://www.ntis.gov/about/form.aspx $>$

Online ordering: http://www.ntis.gov

This document was printed on recycled paper. 


\title{
Secondary Waste Cementitious Waste Form Data Package for the Integrated Disposal Facility Performance Assessment
}

\author{
KJ Cantrell \\ JH Westsik, Jr. \\ RJ Serne \\ W Um \\ AD Cozzi ${ }^{1}$
}

May 2016

Prepared for

the U.S. Department of Energy

under Contract DE-AC05-76RL01830

${ }^{1}$ Savannah River National Laboratory

Pacific Northwest National Laboratory

Richland, Washington 99352 



\section{Executive Summary}

A review of the most up-to-date and relevant data currently available was conducted to develop a set of recommended values for use in the Integrated Disposal Facility performance assessment to model contaminant release from a cementitious waste form for aqueous wastes treated at the Hanford Effluent Treatment Facility. This data package relies primarily upon recent data collected on laboratory-scale cementitious grout formulations fabricated with simulants of liquid secondary wastes expected to be produced at Hanford. These data were supplemented, when necessary, with data developed for Cast Stone and saltstone-low-activity waste cementitious waste forms developed for potential application at Hanford and used at the Savannah River Site, respectively. Included are measurements of effective diffusion coefficients for technetium, iodine, sodium, nitrates, nitrite, chromium, and uranium; technetium desorption distribution coefficients and solubilities; porosity and moisture content; dry bulk and particle densities; and Van Genuchten transport parameters. 


\section{Acknowledgments}

The work reported here was funded by Washington River Protection Solutions (WRPS). Dave Swanberg with WRPS provided programmatic guidance. Gary Smith was the project manager within Pacific Northwest National Laboratory (PNNL).

Technical review of the document was provided by Jeff Serne, Wooyong Um and Nik Qafoku at PNNL; Alex Cozzi, Greg Flach, Connie Herman, Dan Kaplan, and Walt Kubilius at Savannah River National Laboratory; Bob Andrews, Mick Apted, and Rainer Senger with the INTERA performance assessment modeling team; and Dave Swanberg and John Mahoney from WRPS.

Maura Zimmerschied provided real value with her editorial review and assistance in putting together the early drafts of the document for review. 


\section{Acronyms and Abbreviations}

AFm

$\mathrm{AFt}$

ASTM

BFS

CAH

CASH

$\mathrm{CSH}$

COC

DIW

DOE

EPA

EQL

ERDF

ETF

GAC

HTWOS

IDF

ILAW

LAW

LI

LSW

OPC

$\mathrm{PA}$

PNNL

QA

R\&D

RCRA

SDU

SRNL

SRS

SST

TCLP

VZPW

WAC

WRPS alumina, ferric oxide, monosulfate or calcium monosulfoaluminate

alumina, ferric oxide, trisulfate

ASTM International, consensus standards organization, West Conshohocken, Pennsylvania (www.astm.org)

blast furnace slag

calcium aluminate hydrate

calcium aluminate silicate hydrate

calcium silicate hydrate

constituent of concern

deionized water

U.S. Department of Energy

U.S. Environmental Protection Agency

estimated quantitation limit

Environmental Restoration Disposal Facility

Effluent Treatment Facility

granular activated carbon

Hanford Tank Waste Operations Simulator

Integrated Disposal Facility

immobilized low-activity waste

low-activity waste

leachability index

liquid secondary waste

ordinary portland cement

performance assessment

Pacific Northwest National Laboratory

quality assurance

research and development

Resource Conservation and Recovery Act

Saltstone Disposal Unit

Savannah River National Laboratory

Savannah River Site

single-shell tank

Toxicity Characteristic Leaching Procedure

vadose zone pore water

waste acceptance criteria

Washington River Protection Solutions 
WTP

WWFTP
Hanford Tank Waste Treatment and Immobilization Plant

WRPS Waste Form Testing Program 


\section{Contents}

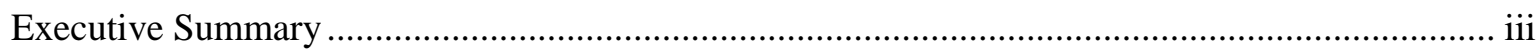

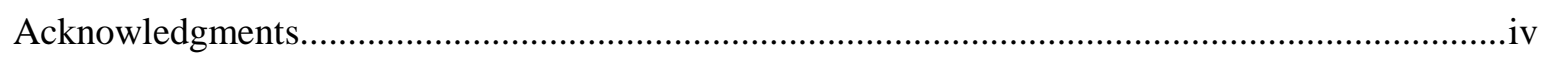

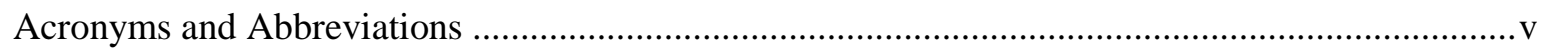

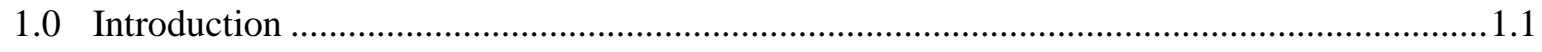

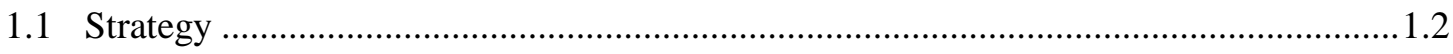

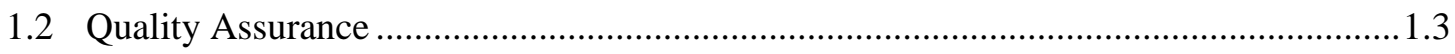

2.0 Characteristics of the Cementitious Waste Forms ............................................................2.1

2.1 Release Modeling from Cementitious Waste Forms..................................................2.8

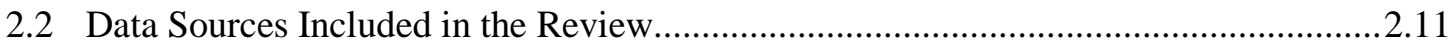

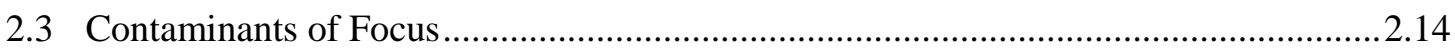

3.0 Review of Contaminant Release Data and Physical and Hydraulic Properties for Cast Stone3.1

3.1 Measurements of Effective Diffusion Coefficients for Key Contaminants ...................... 3.1

3.1.1 Effective Diffusion Coefficients - Technetium ..................................................3.3

3.1.2 Effective Diffusion Coefficients - Iodine ...........................................................

3.1.3 Effective Diffusion Coefficients - Sodium ......................................................... 3.8

3.1.4 Effective Diffusion Coefficients - Nitrate, Nitrite, Chromium, and Uranium...3.10

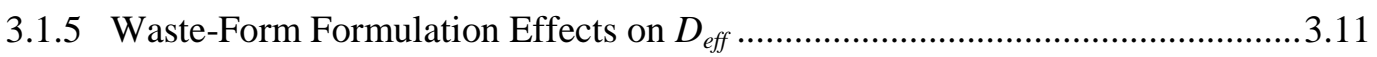

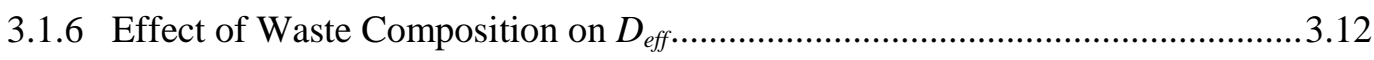

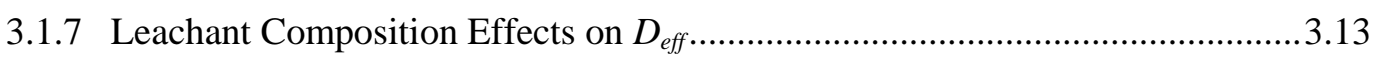

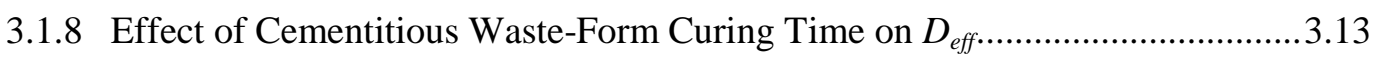

3.1.9 Previous Reviews of Effective Diffusion Coefficients .......................................13

3.2 Recommended Values for Effective Diffusion Coefficients...........................................14

3.3 Cementitious Material $K_{d}$ Values for Key Contaminants................................................. 3.0

3.3.1 ${ }^{99}$ Tc Desorption Distribution Coefficients $\left(K_{d} s\right)$ and Apparent Solubility Values3.1

3.4 Solubility of Contaminant-Bearing Phases ................................................................... 3.2

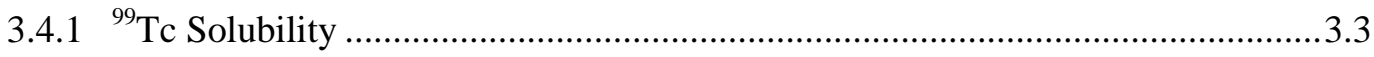

3.5 Physical and Hydraulic Properties of LSW Grouts Relevant to Contaminant Release...3.3

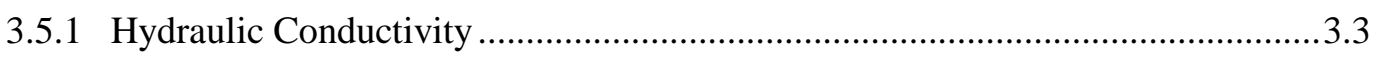

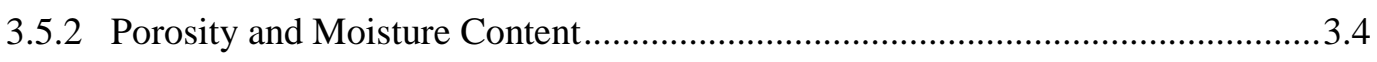

3.5.3 Dry Bulk Density and Particle Density …............................................................

3.5.4 Van Genuchten Transport Parameters................................................................

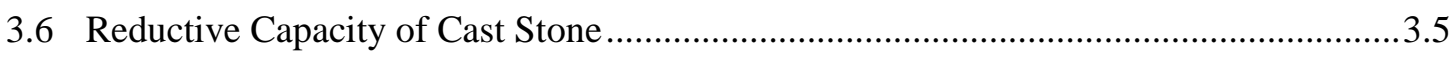

3.7 Release of ${ }^{129}$ I from Grout Encapsulated Activated Carbon ..........................................10

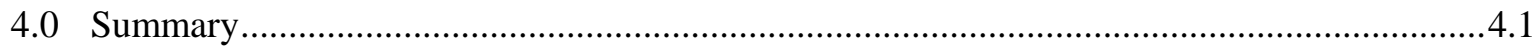

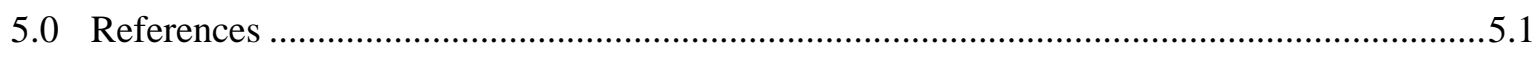

Appendix A - Summary Data on Tc Effective Diffusivity Studies ............................................. A.1 
Appendix B - Simulant Compositions.............................................................................. B.

Appendix C - Mineral Compositions of LSW Grouts.............................................................. C.1

Appendix D - EPA 1313 Results for LSW Grouts........................................................................

Appendix E - Moisture Retention Curves for Selected LSW Grouts.......................................... E.1 


\section{Figures}

2.1 Evolution of Cement Pore Water pH During Weathering Due to Contact with Infiltrating

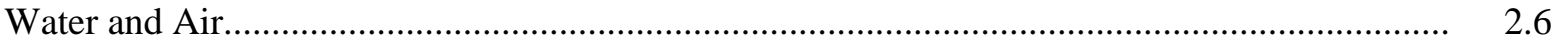

2.2 Conceptual Representation of Tortuosity ....................................................................... 2.9

2.3 Conceptual Representation of Constrictivity ......................................................................... 2.9

3.1 Effective Diffusivity for Selected Waste Components ........................................................... 3.3

3.2 Tc Effective Diffusivities from LSW Grouts Averaged over 28 through 140 days Leaching...... 3.4

3.3 Tc Effective Diffusivities from 0.6 Mix Ratio Fly-Ash-Based Grouts and Cast Stone............... 3.5

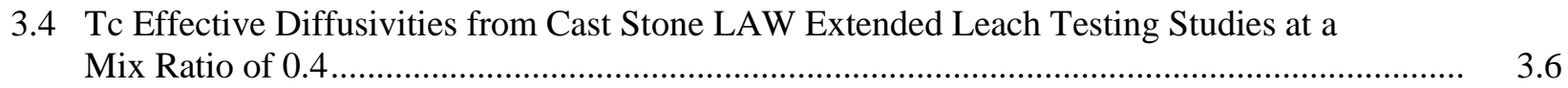

3.5 Tc Effective Diffusivities from Cast Stone LAW Extended Leach Testing Studies at a

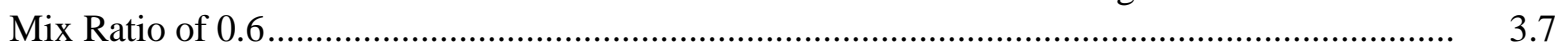

3.6 Na Effective Diffusivities from LSW Lime-Based and Fly-Ash-Based Grouts .......................... 3.8

3.7 Cumulative Fraction Leached in Extended Leach Testing by Serne et al. ................................. 3.10

3.8 Nitrate Effective Diffusivities from LSW Lime-Based and Fly-Ash-Based Grouts .................. 3.12

\section{Tables}

3.1 Recommended Range of Effective Diffusion Coefficients for Cast Stone for Secondary Waste

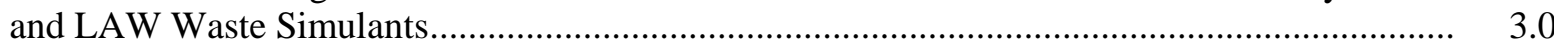

3.2 Recommended Desorption $K_{d}$ Values for Cementitious Materials............................................ 3.1

$3.3{ }^{99}$ Tc Desorption Distribution Coefficients and Solubility....................................................... 3.2

3.4 Density, Porosity, Moisture Content, and Hydraulic Conductivity of Selected LSW Grout

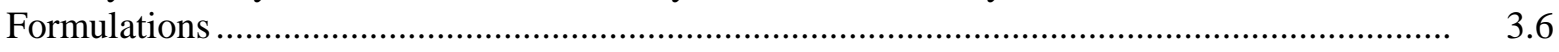

3.5 Density and Porosity of Selected Cast Stone Formulations ..................................................... 3.7

3.6 Van Genuchten Transport Parameters Data............................................................................. 3.8

3.7 95\% Confidence Limits for Van Genuchten Transport Parameters.......................................... 3.8

3.8 Reductive Capacity Measurement Result for Cast Stone Samples Made with LAW Simulants.. 3.9

3.9 Reductive Capacity Results for Secondary Waste Forms without Tc Added............................. 3.10 



\subsection{Introduction}

The Hanford Site in southeastern Washington State has 56 million gallons of radioactive and chemically hazardous wastes stored in 177 underground tanks (ORP 2014). The U.S. Department of Energy (DOE) Office of River Protection (ORP), through its contractors, is constructing the Hanford Tank Waste Treatment and Immobilization Plant (WTP) to convert the radioactive and hazardous wastes into stable glass waste forms for disposal. The high-level waste fraction of the tank wastes will be converted to a glass waste form for disposal at an off-site federal repository. The low-activity waste (LAW) fraction of the wastes will be converted to a separate glass waste form that will be disposed on-site in the Integrated Disposal Facility (IDF).

The IDF is permitted as a Resource Conservation and Recovery Act (RCRA) Subtitle C compliant landfill system for disposal of mixed low-level waste. It will be used for disposal of the immobilized low-activity waste (ILAW) glass waste form, solidified or encapsulated secondary wastes generated from tank farms and WTP operations, and miscellaneous solid waste such as failed glass melters. The IDF will also be used for disposal of non-hazardous solid low-level radioactive waste.

For the ILAW glass, secondary waste, and other wastes to be accepted for disposal in the IDF, it must be demonstrated that the wastes disposed in the IDF do not pose a significant risk to human health and the environment. In accordance with DOE Order 435.1 (DOE 1999) and the associated manual, a performance assessment (PA) will be conducted for the LAW glass and solidified secondary wastes to be disposed of at the IDF. The PA estimates the impacts of disposal of the wastes with respect to potential doses to representative future members of the public due to releases of contamination from the disposal facility. As part of the PA, modeling is conducted to estimate the release of contaminants from the waste forms over the period of compliance and longer time periods to look at longer-term impacts. This modeling requires information on the release of contaminants from the waste forms over time. Testing programs are conducted to provide the data for those analyses. Data packages are compiled with data from the testing programs to provide the bases for the modeling parameters used in the PA analyses. This data package compiles available data necessary for modeling the performance of cementitious waste forms for aqueous waste streams as part of the IDF PA and is an update to and supersedes the cementitious waste form data package prepared by Cantrell (2015). Other data packages have been prepared in the past for the ILAW glass and cementitious waste forms and have recently been updated (Krupka et al. 2004; Rockhold et al. 2015, Last et al. 2015, Pierce et al. 2004, Freedman et al. 2015). A separate data package is being prepared for solid secondary wastes encapsulated in cementitious waste forms (Flach et al. 2016).

As part of the pretreatment and immobilization of LAW in the WTP, liquid secondary wastes (LSWs) will be generated that will be transferred to the Effluent Treatment Facility (ETF) on the Hanford Site for further treatment. The ETF will treat the LSWs to produce 1) a "purified" liquid waste stream for disposal at a state-approved land disposal site, and 2) a concentrated stream to be solidified and stabilized prior to disposal in the IDF. The current baseline solid waste form for this LSW is a cementitious waste form (ORP 2014).

Cast Stone (also called "Containerized Cast Stone”) is a waste form that is produced using a mixture of Class F fly ash, Grade 100 or 120 blast furnace slag (BFS), and Type I and II portland cement. CH2M Hill Hanford Group Inc. developed this waste form to solidify numerous waste streams, including 
secondary waste generated at the Hanford Site. The dry-blend recipe for Cast Stone is nearly identical to that of the Savannah River Site (SRS) saltstone recipe used for solidifying their aqueous LAW waste. Both use the same three dry ingredients (BFS, Class F fly ash, and portland Type I/II cement) and only differ by a few percent in the mix. Cast Stone for this application uses $47 \mathrm{wt} \%$ BFS (Grade 100), $45 \mathrm{wt} \%$ fly ash (Class F), and $8 \mathrm{wt} \%$ portland cement (Type I/II). Saltstone uses $45 \mathrm{wt} \%$ BFS (Grade 100), $45 \mathrm{wt} \%$ fly ash (Class F), and $10 \mathrm{wt} \%$ portland cement (Type I/II). The physical properties of Cast Stone and saltstone, as measured by parameters such as compressive strength, residual free water, bulk density, and porosity, are quite similar (see Section 3.5). The sources of the three dry-blend materials used at each site differ, and general descriptions of the differences are noted in Westsik et al. (2013). Small differences in leaching performance have been observed between Cast Stone made with dry ingredients sourced from the Pacific Northwest and from the Southeastern United States (Westsik et al. 2013), but acceptable waste form performance is expected with the materials sourced in the Northwest.

The projected ETF LSW composition differs from wastes considered for Cast Stone or saltstone to date in that it contains lower free hydroxide and higher sulfate concentrations. Accordingly, a modification to the BFS/fly ash/cement formulation is being investigated to increase calcium to bind the sulfate and raise the $\mathrm{pH}$ in order to activate the slag (Um et al. 2016, Cozzi et al. 2016). This is being done by changing the dry-blend mix to include hydrated lime, removing the fly ash, and adjusting the BFS:cement:hydrated-lime mix ratio. A water-to-dry-mix ratio similar to the original Cast Stone formulation is used to maintain hydraulic properties important during set and final curing. Blast furnace slag is retained for its ability to reduce and retain contaminants such as technetium and chromium. BFS is an important component of these cementitious waste form compositions; its inclusion in the dry-blend mixes yields waste forms with significantly different properties from cementitious waste forms without the BFS. For the purposes of this data package, this new cementitious waste form using hydrated lime will be referred to as an LSW grout. Cementitious waste forms based on specific combinations of BFS, fly ash, and portland cement will be referred to as Cast Stone or saltstone depending upon the specific dry-blend mix.

The purpose of this data package is to provide a review of the most relevant data currently available for modeling contaminant release from a cementitious waste form such as a LSW grout or Cast Stone, and to develop a set of recommended values for use in the IDF PA. This review relies primarily upon more recent data collected on LSW grout and Cast Stone formulations fabricated with simulants of LSW and LAW waste expected to be produced at Hanford. Development and characterization of the LSW has been underway for a little more than a year as this data package is being prepared. The data package presents the information that is available at this time, but recognizes that there is more work to be done to reduce the uncertainty in the measured properties and to provide perspective on the relevance and scalability of the laboratory work conducted to date and the performance of production-scale LSW grout waste form in their containers in the disposal facility. When necessary, data for the LSW grout and Cast Stone were supplemented with data for SRS's saltstone.

\subsection{Strategy}

The strategy for the selection, development, and characterization of a waste form for solidifying Hanford aqueous secondary wastes was developed in 2008. The DOE sponsored a meeting to develop a roadmap to outline the steps necessary to design the secondary waste forms. Representatives from DOE, the U.S. Environmental Protection Agency (EPA), the Washington State Department of Ecology, the 
Oregon Department of Energy, the Nuclear Regulatory Commission, and technical experts from the DOE national laboratories, academia, and private consultants convened in Richland, Washington, during the week of July 21-23, 2008, to participate in a workshop to identify the risks and uncertainties associated with the treatment and disposal of the secondary wastes and to develop a roadmap for addressing those risks and uncertainties (PNNL 2009). That roadmap then guided a program that identified and characterized candidate secondary waste forms, which led to the selection of a cementitious waste form for solidification of Hanford Site LSWs (Roe and Parker 2012).

With the selection of a cementitious waste form as a baseline for secondary wastes, testing and wasteform qualification plans have been developed and implemented to guide the further development and refinement of the cementitious waste form (Ramsey and Robbins 2012, Westsik and Serne 2012). Most recently, a recommended technical approach document has been prepared to guide waste-form testing to support the IDF PA (Yabusaki et al. 2015).

The testing program builds upon the experiences with cementitious waste forms at both SRS and Hanford. It includes standardized test methods including those of ASTM International (ASTM) and the most recent EPA methods for characterizing retention and release of contaminants from solid materials.

\subsection{Quality Assurance}

This work was conducted with funding from Washington River Protection Solutions (WRPS) under contract 36437-192, Secondary Waste Cast Stone Formulation and Waste Form Qualification. The work was conducted as part of Pacific Northwest National Laboratory (PNNL) Project 68334.

All research and development (R\&D) work at PNNL is performed in accordance with PNNL's laboratory-level Quality Management Program, which is based on a graded application of NQA-1-2000, Quality Assurance Requirements for Nuclear Facility Applications, to R\&D activities. In addition to the PNNL-wide quality assurance (QA) controls, the QA controls of the WRPS Waste Form Testing Program (WWFTP) QA program were also implemented for the work. The WWFTP QA program consists of the WWFTP Quality Assurance Plan (QA-WWFTP-001) ${ }^{1}$ and associated QA-NSLW-numbered procedures that provide detailed instructions for implementing NQA-1 requirements for R\&D work. The WWFTP QA program is based on the requirements of NQA-1-2008, Quality Assurance Requirements for Nuclear Facility Applications, and NQA-1a-2009, Addenda to ASME NQA-1-2008 Quality Assurance Requirements for Nuclear Facility Applications, graded on the approach presented in NQA-1-2008, Part IV, Subpart 4.2, "Guidance on Graded Application of Quality Assurance (QA) for Nuclear-Related Research and Development.”

Performance of this work and preparation of this report were assigned the technology level "Applied Research” and were conducted in accordance with procedure QA-NSLW-1102, Scientific Investigation for Applied Research. All staff members contributing to the work have technical expertise in the subject matter and received QA training prior to performing quality-affecting work. The "Applied Research" technology level provides adequate controls to ensure that the activities were performed correctly. Use of both the PNNL-wide and WWFTP QA controls ensured that all client QA expectations were addressed in performing the work.

\footnotetext{
${ }^{1}$ MacPherson DB. 2013. WRPS Waste Form Testing Program Quality Assurance Plan. Pacific Northwest National
} Laboratory, Richland, WA. 
Work cited herein by Um et al. (2016), Cozzi et al. (2016), Serne et al. (2015), and Westsik et al. (2013) was conducted under QA programs meeting ASME NQA-1 requirements. 


\subsection{Characteristics of the Cementitious Waste Forms}

Cementitious waste forms are produced by mixing dry reagents with the liquid waste. Typical dry ingredients consist of 1) portland cement, 2) fly ash, and 3) BFS (Wilhite et al. 1988; Langton 1989). Formulations that incorporate alkali silicates such as fly ash and BFS can produce cements with equivalent strength as well as superior long-term durability and leach resistance compared to portland cement-based materials. Fly ash is used in the formulation as a functional extender to control heat of hydration and reduce permeability (Langton 1987). The BFS is used in some formulations to reduce redox-sensitive elements [such as technetium (Tc), uranium (U), and chromium (Cr)], causing them to precipitate as insoluble compounds, and thereby lowering their release rates from the cured cementitious waste form.

An overview of the more important chemical reactions involved with cement hydration has been presented previously in Sundaram et al. (2011). Some of this material is reiterated here. The chemistry of cement-based waste forms is summarized as follows. Ordinary portland cement (OPC) consists of four main phases: tricalcium silicate $\left[(\mathrm{CaO})_{3} \cdot \mathrm{SiO}_{2}\right.$ or $\left.\mathrm{Ca}_{3} \mathrm{SiO}_{5}\right]$, dicalcium silicate $\left[(\mathrm{CaO})_{2} \cdot \mathrm{SiO}_{2}\right.$ or $\left.\mathrm{Ca}_{2} \mathrm{SiO}_{4}\right]$, tricalcium aluminate $\left[(\mathrm{CaO})_{3} \cdot \mathrm{Al}_{2} \mathrm{O}_{3}\right.$ or $\left.\mathrm{Ca}_{3} \mathrm{Al}_{2} \mathrm{O}_{6}\right]$, and tetracalcium aluminoferrite $\left[(\mathrm{CaO})_{4} \cdot \mathrm{Al}_{2} \mathrm{O}_{3} \cdot \mathrm{Fe}_{2} \mathrm{O}_{3}\right.$ or $\mathrm{Ca}_{4} \mathrm{Al}_{2} \mathrm{Fe}_{2} \mathrm{O}_{10}$ ]. Because the amount of $\mathrm{Ca}_{3} \mathrm{SiO}_{5}$ is about $60 \%$ or higher, $\mathrm{Ca}_{3} \mathrm{SiO}_{5}$ hydration is the primary phase to affect the behavior of portland cement paste. Hydration stoichiometry is presented in equation (2.1) (Mindess et al. 2003):

$$
\left.2\left[(\mathrm{CaO})_{3} \mathrm{SiO}_{2}\right]+11 \mathrm{H}_{2} \mathrm{O} \rightarrow(\mathrm{CaO})_{3}\left(\mathrm{SiO}_{2}\right)_{2}\left(\mathrm{H}_{2} \mathrm{O}\right)_{8} \text { (usually described as } \mathrm{CSH}\right)+3\left[\mathrm{CaO} \cdot \mathrm{H}_{2} \mathrm{O}\right]
$$

where CSH indicates poorly crystalline or amorphous calcium silicate hydrate of unspecified composition (Taylor 1997). The calcium/silicate ratio typically varies around 1.5 2.0 in normal concrete.

This reaction is often disregarded because hydration of $(\mathrm{CaO})_{2} \mathrm{SiO}_{2}$ is very similar to hydration of $(\mathrm{CaO})_{3} \mathrm{SiO}_{2}$, but slower. This is because the heat evolution of $(\mathrm{CaO})_{2} \mathrm{SiO}_{2}$ hydration is less than that of $(\mathrm{CaO})_{3} \mathrm{SiO}_{2}$ and the amount of $(\mathrm{CaO})_{2} \mathrm{SiO}_{2}$ phases in OPC is also smaller than the amount of $(\mathrm{CaO})_{3} \mathrm{SiO}_{2}$. Hydration stoichiometry is given in equation (2.2) (Mindess et al. 2003):

$$
2\left[(\mathrm{CaO})_{2} \mathrm{SiO}_{2}\right]+9 \mathrm{H}_{2} \mathrm{O} \rightarrow(\mathrm{CaO})_{3}\left(\mathrm{SiO}_{2}\right)_{2}\left(\mathrm{H}_{2} \mathrm{O}\right)_{8}+\mathrm{CaO} \cdot \mathrm{H}_{2} \mathrm{O}
$$

To produce portland cement, clinker is inter-ground with a few percent of gypsum. The role of gypsum is to prevent the rapid hydration of $(\mathrm{CaO})_{3} \cdot \mathrm{Al}_{2} \mathrm{O}_{3}$ by forming protective layers of ettringite at the surface of $(\mathrm{CaO})_{3} \cdot \mathrm{Al}_{2} \mathrm{O}_{3}$, which hinders the dissolution rate of $(\mathrm{CaO})_{3} \cdot \mathrm{Al}_{2} \mathrm{O}_{3}$ (Mindess et al. 2003). When gypsum is not present in the cement, flash set occurs by rapid AFm formation, which results in an irrecoverable stiffening process of the mixture with a large evolution of heat due to rapid reaction of $(\mathrm{CaO})_{3} \cdot \mathrm{Al}_{2} \mathrm{O}_{3}$ (Taylor 1997). AFm is an abbreviation for "alumina, ferric oxide, monosulfate" or $\left(\mathrm{Al}_{2} \mathrm{O}_{3}-\mathrm{Fe}_{2} \mathrm{O}_{3}-\right.$ mono). It represents a group of calcium aluminate hydrates with the general formula $\left.\left[\mathrm{Ca}_{2}(\mathrm{Al}, \mathrm{Fe})(\mathrm{OH})_{6}\right)\right] \cdot \mathrm{X} \cdot \mathrm{nH}_{2} \mathrm{O}$ where $\mathrm{X}$ represents a singly charged anion or "half" a doubly charged anion. $\mathrm{X}$ may be one of many anions. The most important anions involved in portland cement hydration are hydroxyl, sulfate, and carbonate. The most common AFm phase in hydrated cement is calcium monosulfoaluminate. The reaction stoichiometry causing flash set is given by equation (2.3) (Mindess et al. 2003):

$$
2\left[(\mathrm{CaO})_{3} \cdot \mathrm{Al}_{2} \mathrm{O}_{3}\right]+21 \mathrm{H}_{2} \mathrm{O} \rightarrow(\mathrm{CaO})_{4} \cdot \mathrm{Al}_{2} \mathrm{O}_{3} \cdot\left(\mathrm{H}_{2} \mathrm{O}\right)_{13}+(\mathrm{CaO})_{2} \cdot \mathrm{Al}_{2} \mathrm{O}_{3} \cdot\left(\mathrm{H}_{2} \mathrm{O}\right)_{8}
$$


When gypsum $\left[(\mathrm{CaO}) \cdot \mathrm{SO}_{3} \cdot\left(\mathrm{H}_{2} \mathrm{O}\right)_{2}\right.$ or $\left.\mathrm{CaSO}_{4} \cdot\left(\mathrm{H}_{2} \mathrm{O}\right)_{2}\right]$ is present, $(\mathrm{CaO})_{3} \cdot \mathrm{Al}_{2} \mathrm{O}_{3}$ hydrates to form ettringite. The reaction stoichiometry of $(\mathrm{CaO})_{3} \cdot \mathrm{Al}_{2} \mathrm{O}_{3}$ to form ettringite is shown in equation (2.4) (Mindess et al. 2003):

$$
(\mathrm{CaO})_{3} \cdot \mathrm{Al}_{2} \mathrm{O}_{3}+3\left[(\mathrm{CaO}) \cdot \mathrm{SO}_{3} \cdot\left(\mathrm{H}_{2} \mathrm{O}\right)_{2}\right]+26 \mathrm{H}_{2} \mathrm{O} \rightarrow(\mathrm{CaO})_{6} \cdot \mathrm{Al}_{2} \mathrm{O}_{3} \cdot\left(\mathrm{SO}_{3}\right)_{3} \cdot\left(\mathrm{H}_{2} \mathrm{O}\right)_{32} \text { (ettringite, AFt) (2.4) }
$$

The compound $(\mathrm{CaO})_{6} \cdot \mathrm{Al}_{2} \mathrm{O}_{3} \cdot\left(\mathrm{SO}_{3}\right)_{3} \cdot\left(\mathrm{H}_{2} \mathrm{O}\right)_{32}$ is ettringite. AFt is an abbreviation for "alumina, ferric oxide, trisulfate" or $\left(\mathrm{Al}_{2} \mathrm{O}_{3}-\mathrm{Fe}_{2} \mathrm{O}_{3}-\right.$ tri). It represents a group of calcium sulfoaluminate hydrates. AFt has the general formula $\left[\mathrm{Ca}_{3}(\mathrm{Al}, \mathrm{Fe})(\mathrm{OH})_{6} \cdot 12 \mathrm{H}_{2} \mathrm{O}\right] 2 \cdot \mathrm{X}_{3} \cdot \mathrm{nH}_{2} \mathrm{O}$ where $\mathrm{X}$ represents a doubly charged anion or, sometimes, two singly charged anions. Ettringite is the most common and important member of the AFt group ( $\mathrm{X}$ in this case denoting sulfate). Normally, sulfate is consumed before the $(\mathrm{CaO})_{3} \cdot \mathrm{Al}_{2} \mathrm{O}_{3}$ has completely hydrated. When gypsum is depleted, further $(\mathrm{CaO})_{3} \cdot \mathrm{Al}_{2} \mathrm{O}_{3}$ hydration causes the $\mathrm{pH}$ to increase, and ettringite becomes unstable and transforms to calcium monosulfoaluminate. The reaction stoichiometry of calcium monosulfoaluminate formation is shown in equation (2.5) (Mindess et al. 2003):

$$
2\left[(\mathrm{CaO})_{3} \cdot \mathrm{Al}_{2} \mathrm{O}_{3}\right]+(\mathrm{CaO})_{6} \cdot \mathrm{Al}_{2} \mathrm{O}_{3} \cdot\left(\mathrm{SO}_{3}\right)_{3} \cdot\left(\mathrm{H}_{2} \mathrm{O}\right)_{32}+4 \mathrm{H}_{2} \mathrm{O} \rightarrow 3\left[(\mathrm{CaO})_{4} \cdot \mathrm{Al}_{2} \mathrm{O}_{3} \cdot \mathrm{SO}_{3} \cdot\left(\mathrm{H}_{2} \mathrm{O}\right)_{12}\right]
$$

The compound $(\mathrm{CaO})_{4} \cdot \mathrm{Al}_{2} \mathrm{O}_{3} \cdot \mathrm{SO}_{3} \cdot\left(\mathrm{H}_{2} \mathrm{O}\right)_{12}$ is calcium monosulfoaluminate $(\mathrm{AFm})$. From this point, the diffusion barrier afforded by the ettringite is broken, and remaining $(\mathrm{CaO})_{3} \cdot \mathrm{Al}_{2} \mathrm{O}_{3}$ reacts rapidly. In OPC, the molar ratio of $\mathrm{SO}_{3}$ to $(\mathrm{CaO})_{3} \cdot \mathrm{Al}_{2} \mathrm{O}_{3}$ ranges from 0.7 to 1.2, suggesting that the final hydration product will not be ettringite, but mainly calcium monosulfoaluminate or some other form of AFm. Because hydroxyl ion $\left(\mathrm{OH}^{-}\right)$is substituted in the phase structure, it is often referred to as hydroxyl AFm. Similarly, 3[(CaO) $\left.)_{4} \cdot \mathrm{Al}_{2} \mathrm{O}_{3} \cdot \mathrm{SO}_{3} \cdot\left(\mathrm{H}_{2} \mathrm{O}\right)_{12}\right]$ is referred to as sulfate AFm because $\mathrm{SO}_{4}{ }^{2-}$ ion is substituted in the phase structure. Under favorable conditions, AFm forms hexagonal plates. Some AFm in portland cement paste is of these types, but much is poorly crystalline and intimately mixed with CSH (Taylor 1997). However, $(\mathrm{CaO})_{6} \cdot \mathrm{Al}_{2} \mathrm{O}_{3} \cdot\left(\mathrm{SO}_{3}\right)_{3} \cdot\left(\mathrm{H}_{2} \mathrm{O}\right)_{32}$ contains three $\mathrm{SO}_{3}$ in its structure, so it is referred to as trisulfate. AFt usually indicates ettringite because this is the most common phase in the cement.

The compound $(\mathrm{CaO})_{4} \cdot \mathrm{Al}_{2} \mathrm{O}_{3} \cdot \mathrm{Fe}_{2} \mathrm{O}_{3}\left(\mathrm{Ca}_{4} \mathrm{Al}_{2} \mathrm{Fe}_{2} \mathrm{O}_{10}\right)\left(\mathrm{C}_{4} \mathrm{AF}\right)$ forms hydration products similar to those of $(\mathrm{CaO})_{3} \cdot \mathrm{Al}_{2} \mathrm{O}_{3}$, with or without gypsum (Mindess et al. 2003), and $(\mathrm{CaO})_{4} \cdot \mathrm{Al}_{2} \mathrm{O}_{3} \cdot \mathrm{Fe}_{2} \mathrm{O}_{3}$ hydrates much more slowly than $\mathrm{C}_{3} \mathrm{~A}$; thus, it is less likely to cause flash set. In addition, gypsum retards $\mathrm{C}_{4} \mathrm{AF}$ hydration much more significantly than it retards $(\mathrm{CaO})_{3} \cdot \mathrm{Al}_{2} \mathrm{O}_{3}$ hydration. Therefore, $(\mathrm{CaO})_{4} \cdot \mathrm{Al}_{2} \mathrm{O}_{3} \cdot \mathrm{Fe}_{2} \mathrm{O}_{3}$ hydration is less important than $(\mathrm{CaO})_{3} \cdot \mathrm{Al}_{2} \mathrm{O}_{3}$ hydration with respect to stiffening and set.

In the cementitious dry-blend formulation currently under evaluation for the LSW waste form, the role of portland cement is to provide the source for CSH formation. The LSW waste form has sufficient portlandite from the hydrated lime addition, and sulfate from the waste stream, such that ettringite readily forms. Although the $\mathrm{pH}$ of the pore solution is elevated (Cozzi et al. 2016), x-ray diffraction analysis of waste forms cured less than 2 months did not identify the expected AFm phase indicative of the transformation of ettringite over time (Um et al. 2016, Cozzi et al. 2016).

Calcium Silicate Hydrate (CSH): Because of its amorphous character, compositional variability, and poorly resolved morphology, CSH is a difficult material to study (Mindess et al. 2003). CSH makes up over one half of the volume of hydrated paste, and therefore it is the most important component. It is generally understood that CSH is the strongest material in concrete; thus, more production of CSH is always preferable. 
During early hydration, CSH grows out from the particle surface into the surrounding water-filled space in the form of low-density thin sheets. Once hydration has become diffusion controlled, CSH forms primarily as a denser coating around the hydrating cement grains, referred to as either late or inner product. These coatings form the diffusion barrier during later hydration and thicken with time, growing inward as well as outward. The coatings maintain the shape of the original cement grains.

Calcium Hydroxide [Ca(OH) $)_{2}$, also known as hydrated lime or portlandite: Unlike $\mathrm{CSH}$, $\mathrm{Ca}(\mathrm{OH})_{2}$ is a well crystallized material that has a distinctive hexagonal morphology. Unlike CSH, $\mathrm{Ca}(\mathrm{OH})_{2}$ is crystallized in the pore solution during hydration. It occupies about 20 to $25 \%$ of the paste solid volume, so it also plays an important role. Normally, it provides the source of hydroxide to protect the stability of $\mathrm{CSH}$ in the cement paste. However, $\mathrm{Ca}(\mathrm{OH})_{2}$ is not a strong material, so it does not contribute as much to the strength and durability of cement paste.

In the cementitious dry-blend formulation currently under evaluation for the LSW waste form, the role of hydrated lime is to 1 ) provide a source of calcium to react with the sulfate in the liquid secondary waste, and 2) raise the $\mathrm{pH}$ of the near neutral liquid secondary waste to activate the BFS.

Ettringite and Monosulfoaluminate: These products are relatively minor constituents of hydrated cement paste, making up only 10 to $15 \%$ by solid volume. Considering that most of the hydration products consist of $\mathrm{CSH}$ and $\mathrm{Ca}(\mathrm{OH})_{2}$, these two phases play a relatively minor role in the microstructural development of hydrated cement paste. Ettringite has a sharp, needle-like microstructure, and monosulfoaluminate forms as hexagonal plates. These phases are metastable, which means that the phase can change according to surrounding conditions, especially with ingress of sulfates. The phase change from monosulfate (AFm) to trisulfate (AFt) occurs accordingly and generates expansive forces, which are known to cause serious cracking in the hardened paste (Taylor 1997; Mehta and Monteiro 2006). The cause of expansion pressure is still in debate, but one of two hypotheses is generally agreed upon: 1) expansion directly caused by the crystal growth of ettringite, or 2) swelling due to adsorption of water in an alkaline environment by poorly crystalline ettringite.

In the LSW waste form, Um et al. (2016) showed ettringite concentrations in the range of 10-20\% (see Appendix C). In the time frame of the testing, no AFt phase was detected in x-ray diffraction analysis.

Pozzolanic Reaction: A pure pozzolanic reaction can be represented as the consumption of $\mathrm{Ca}(\mathrm{OH})_{2}$ by $\mathrm{SiO}_{2}$ to produce CSH. Such a conversion is done by adding amorphous or reactive silica in the cement paste as shown in equation (2.6) (Mindess et al. 2003).

$$
\mathrm{Ca}(\mathrm{OH})_{2}+\mathrm{SiO}_{2}+\mathrm{H}_{2} \mathrm{O} \rightarrow \mathrm{CaO} \cdot \mathrm{SiO}_{2} \cdot\left(\mathrm{H}_{2} \mathrm{O}\right)_{2}(\mathrm{CSH})
$$

In a normal case, the composition of CSH formed from pozzolans is not very different from the composition of CSH from OPC hydration. However, with very reactive pozzolans of high silica content (silica fume and rice husk ash), the calcium-to-silicate ratio is significantly different, being close to 1.0, and the hydrogen-to-silicate ratio is slightly lower.

Small quantities of reactive alumina in a pozzolan generally substitute for silica as part of the CSH. When a pozzolan has appreciable quantities of reactive alumina (e.g., natural pozzolans or calcined clay-like metakaolin, Class F fly ash, or BFS), a separate set of secondary reactions can occur, leading to 
the formation of calcium aluminate hydrates: calcium aluminate silicate hydrate [CASH, equation (2.7)] and calcium aluminate hydrate [CAH, equation (2.8)] (Mindess et al. 2003).

$$
\begin{gathered}
\mathrm{CSH}+\mathrm{Al}_{2} \mathrm{O}_{3} \rightarrow \mathrm{CASH} \\
\mathrm{Ca}(\mathrm{OH})_{2}+\mathrm{Al}_{2} \mathrm{O}_{3}+\mathrm{H}_{2} \mathrm{O} \rightarrow \mathrm{CaO} \cdot \mathrm{Al}_{2} \mathrm{O}_{3} \cdot\left(\mathrm{H}_{2} \mathrm{O}\right)_{2}(\mathrm{CAH})
\end{gathered}
$$

The exact composition of calcium aluminate silicate hydrates or calcium aluminate hydrates depends on the particular pozzolan, and may include $(\mathrm{CaO})_{2} \cdot \mathrm{Al}_{2} \mathrm{O}_{3} \cdot\left(\mathrm{H}_{2} \mathrm{O}\right)_{8},(\mathrm{CaO})_{2} \cdot \mathrm{Al}_{2} \mathrm{O}_{3} \cdot \mathrm{SiO}_{2} \cdot\left(\mathrm{H}_{2} \mathrm{O}\right)_{8}$, or monosulfoaluminate.

Because the pozzolanic reaction consumes physically weaker $\mathrm{Ca}(\mathrm{OH})_{2}$ and produces physically stronger $\mathrm{CSH}, \mathrm{CAH}$, or CASH, pozzolanic materials are often incorporated into the concrete to improve strength and durability. Pozzolans include fly ash, silica fume, ground granulated BFS, and other calcined natural pozzolanic materials, such as rice husk ash and metakaolin (Mindess et al. 2003). All of these materials are waste by-products of industry (except metakaolin).

Fly Ash: The most typical pozzolanic material is fly ash. This is a glassy round-shaped by-product that is produced from burning coal in electricity-generating power plants. It is known that round-shape particles enhance the workability of the concrete mixtures. Fly ash particle sizes vary around a mean of $10 \sim 15 \mu \mathrm{m}$. According to ASTM C618, the Standard Specification for Coal Fly Ash and Raw or Calcined Natural Pozzolan for Use in Concrete, by-product fly ashes are classified into $\mathrm{C}$ and $\mathrm{F}$ types. To be Class F, the sum of $\mathrm{SiO}_{2}, \mathrm{Al}_{2} \mathrm{O}_{3}$, and $\mathrm{Fe}_{2} \mathrm{O}_{3}$ should be higher than $70 \%$.

Typically, Class F is produced from bituminous or subbituminous coal, and Class $\mathrm{C}$ is produced from lignitic coal. Class $\mathrm{C}$ contains a higher level of calcium oxide, which corresponds quite well with the sum of other oxides and can exhibit hydraulic properties on its own. Many of these constituents are present in the glass fraction of the material. Class $\mathrm{F}$ fly ash has a $\mathrm{CaO}$ content, around 3 5\% (aluminosilicate glass), whereas Class $\mathrm{C}$ fly ash has a $\mathrm{CaO}$ content, around 20 30\% (calcium aluminosilicate glass). Generally, the $\mathrm{CaO}$ content of $10 \%$ is understood as a guideline to distinguish between high-calcium and low-calcium fly ash. Although ASTM International specifies use of total oxide contents to classify fly ashes, many researchers tend to use the term "high calcium" and "low calcium" fly ash rather than Class C and Class F fly ash (Mindess et al. 2003; Taylor 1997; Hewlett 1998; Mehta and Monteiro 2006). This is because the $\mathrm{CaO}$ content strongly influences the pozzolanic properties of the material. Fly ash with higher $\mathrm{CaO}$ content favors the hydration reactions, although it retains some pozzolanic activity.

Blast Furnace Slag: Slags are residues from metallurgical processes, either from producing metals from ore or from refining impure metals. They are derived from lime-based inorganic fluxes used to extract impurities from metals, which solidify on cooling. The cooling rate determines the crystallinity of the slag (faster cooling yields more amorphous slag; slower cooling yields more crystalline slag). The slags used in concrete typically come from the blast furnace production of iron from ore. BFSs are rich in lime, silica, and alumina. Typical mass percentages are $\mathrm{CaO}=35 \sim 45 \%, \mathrm{SiO}_{2}=32 \sim 38 \%$, $\mathrm{Al}_{2} \mathrm{O}_{3}=8 \sim 16 \%, \mathrm{MgO}=5 \sim 15 \%, \mathrm{Fe}_{2} \mathrm{O}_{3}<2 \%$, and sulfur $=1 \sim 2 \%$ (Mindess et al. 2003). Since the $\mathrm{CaO}$ content is high, slag can hydrate in the presence of water. Slags are ground to achieve about the same particle size as cement $(10 \sim 15 \mu \mathrm{m})$. In slags with relatively high aluminum content, gypsum is interground to prevent the rapid hydration of tricalcium aluminate. Slag has been added to waste-form formulations to reduce mobility of constituents of concern (COCs) (Langton 1987). 
Cast Stone: Cast Stone is composed of OPC, Class F fly ash, and BFS. The hydration of Cast Stone will therefore follow the significant characteristics of these materials as explained above. However, it should be noted that the current Cast Stone recipe uses $8 \%$ cement, $45 \%$ Class F fly ash, and $47 \%$ grade 100 slag by weight. Therefore, the effect of cement hydration is minimal, and the effect of fly ash and slag reaction is more dominant with Cast Stone. As mentioned above, the major reaction of the fly ash and slag in the cement-rich paste is pozzolanic. Because the production of calcium hydroxide in Cast Stone is limited due to the smaller quantity of cement, the reaction by fly ash and slag can be enhanced by intentionally adding free hydroxide as an activator. In the case of LSW, this can be done by substituting lime $(\mathrm{CaO})$ or hydrated lime $\left(\mathrm{Ca}(\mathrm{OH})_{2}\right)$ for a portion of the fly ash. Lime is more exothermic than hydrated lime, but is also less stable in air (hydrates into hydrated lime).

LSW grout: The differences between Cast Stone and LSW grout formulation are rooted in the substantive differences between the composition of the LAW waste stream (Russell et al. 2013), and the current LSW waste stream (Um et al. 2016). The LAW waste stream treated to make Cast Stone is a 5-7.5 M sodium solution (25-35 wt\% solids, $\mathrm{pH}>14$ ) with nitrate and hydroxide as the major anions. The current LSW waste streams are primarily ammonium sulfate (10-20\% solids) and are near neutral $\mathrm{pH}$. Therefore, the cementitious materials are different and the reactions that occur may vary. One of the reactions unique to the LSW grout is the formation of gypsum, and subsequently ettringite, during mixing.

$$
2 \mathrm{Ca}(\mathrm{OH})_{2}+\left(\mathrm{NH}_{4}\right)_{2} \mathrm{SO}_{4}+\mathrm{H}_{2} \mathrm{SO}_{4} \rightarrow \mathrm{CaSO}_{4(\mathrm{~s})}+2 \mathrm{NH}_{3} \uparrow+4 \mathrm{H}_{2} \mathrm{O}
$$

Significant factors that affect long-term contaminant release from cementitious waste forms are the chemical reaction pathways that occur as the cementitious waste forms interact with air and water in the subsurface environment. Most contaminants are metal-like, and thus their aqueous solution chemistry is sensitive to $\mathrm{pH}$ conditions. The composition of pore water that evolves during the degradation of cement in water has been studied extensively, both in the laboratory and with computer modeling techniques. The chemical reactions associated with the hydration of cement are described in detail in IAEA (1993), Atkins and Glasser (1992), and Reardon (1992), and the references cited therein. The $\mathrm{pH}$ changes that occur as the result of cement and water reactions are shown schematically as a function of time in Figure 2.1. Note that the $\mathrm{pH}$ evolution of cementitious waste forms made with highly caustic liquid wastes typical of most LAW and some secondary wastes may differ somewhat from this depiction (i.e., remain in the $\mathrm{pH}>12$ region longer until the free hydroxide is leached away). The description of the pore fluid reactions and dissolution of CSH gel do not necessarily represent the degradation of LSW grouts nor Cast Stone. For natural subsurface conditions at Hanford, the sediment pore water $\mathrm{pH}$ is typically approximately 7.5 to 8.3 and is buffered by carbonate/bicarbonate reactions. 


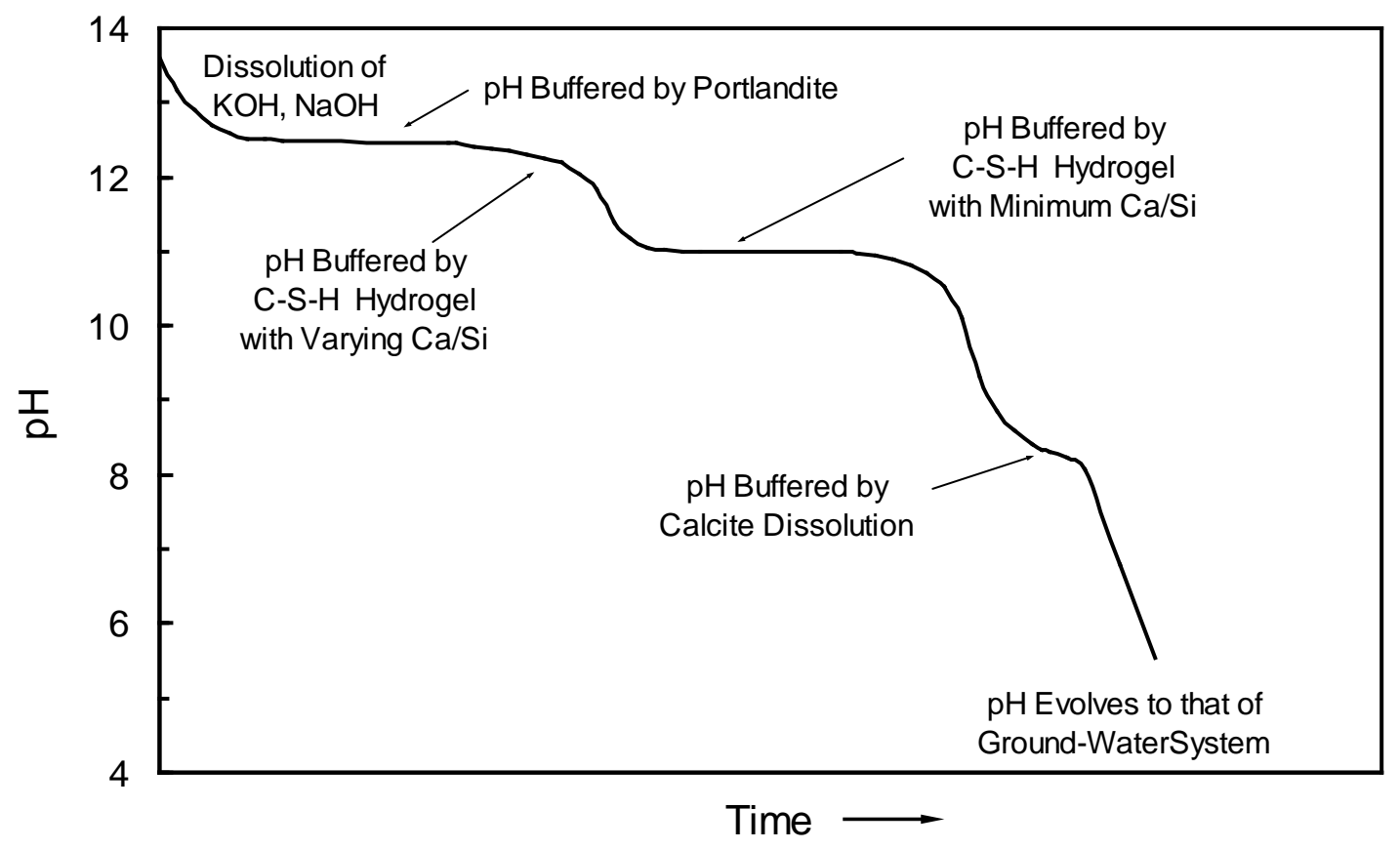

Figure 2.1. Evolution of Cement Pore Water $\mathrm{pH}$ During Weathering Due to Contact with Infiltrating Water and Air. CSH hydrogel is the amorphous calcium (C) silicate (S) hydrate $\left(\mathrm{H}=\mathrm{H}_{2} \mathrm{O}\right)$ solid formed. Figure from Krupka and Serne (1996).

The dissolution of the CSH and portlandite phases, included on the right-hand sides of equations (2.1) and (2.2) and left-hand sides of equations (2.3) and (2.4), which may constitute as much as $75 \mathrm{wt} \%$ of the hydrated cement, has an important role in buffering the $\mathrm{pH}$ of the resulting pore fluids. As recharge water percolates into and around the cementitious forms, dissolution of the alkali hydroxide phases present in relatively minor amounts can result in initially high $\mathrm{pH}$ values (approximately 13.5). As these phases are leached from the cement, the pore fluid $\mathrm{pH}$ decreases to approximately 12.5 , and is buffered by the dissolution of free portlandite contained in the cement.

Eventually, the portlandite is depleted and the pore fluid $\mathrm{pH}$ continues to decrease to approximately 10.5, where it is controlled by the incongruent dissolution of CSH. The solubility properties of CSH, however, vary as a function of its calcium/silicon ratio (Ca/Si ratio). The incongruent dissolution of the $\mathrm{CSH}$ produces mainly dissolved $\mathrm{Ca}(\mathrm{OH})_{2}$, and only traces of dissolved $\mathrm{SiO}_{2}$. During this process, the $\mathrm{Ca} / \mathrm{Si}$ ratio of the remaining CSH solid decreases depending on the solid/solution ratio (Berner 1992). When the dissolution of CSH is complete, the $\mathrm{pH}$ of the cement pore fluid will continue to decrease to a value buffered by the host recharge or vadose zone pore water (VZPW). This continuous $\mathrm{pH}$ change will also be affected to a limited extent by the dissolution of calcite that precipitated at the high-pH conditions during the early stages of cement dissolution, especially in unsaturated environments where gaseous $\mathrm{CO}_{2}$ is available.

The time frame required for the cement pore fluid $\mathrm{pH}$ to change from 13.5 to that of the native recharge water is determined by the rate at which water infiltrates to and through the cement system. For example, calculations by Atkinson et al. (1989) indicate that the $\mathrm{pH}$ of the near-field pore water would remain above 10.5 for several hundred thousand years (groundwater flow rate of $0.32 \mathrm{~cm} / \mathrm{yr}$ and 10 -meter repository dimension in direction of flow) for designs of radioactive waste disposal systems being 
considered in the United Kingdom. Criscenti et al. (1996) performed calculations for three rows of 55gallon cement-filled drums stacked on top of each other in a shallow land burial ground in the arid Hanford environment for various scenarios. For all scenarios modeled, the system $\mathrm{pH}$ did not decrease below 10 for 10,000 years because CSH gel remained to buffer the $\mathrm{pH}$. For a scenario of one barrel filled only one-third with cement at the highest recharge rate $(5 \mathrm{~cm} / \mathrm{yr})$, the $\mathrm{CSH}$ gel was completely depleted after 4,000 years, and the $\mathrm{pH}$ dropped to below 10. Possible container configurations for the secondary waste cementitious waste forms destined for burial in IDF include 55-gallon drums and $2.5 \mathrm{ft} \times 8 \mathrm{ft} \times 20 \mathrm{ft}$, as rectangular mild-steel burial boxes. It is acknowledged that the computer generated predictions by Atkinson et al. (1989) and Criscenti et al. (1996) did not address the potential for significant cement waste-form degradation, aside from a few simple thermodynamically controlled weathering reactions for the major cement phases. Thus, their results showing such long times for $\mathrm{pH}$ to be maintained at alkaline values close to 10 to 10.5 should be carefully considered. The network of chemical reactions (both thermodynamic and kinetically controlled) as well as the computer codes capable of solving the complex network of cement weathering reactions have vastly improved over the 20 to 25 years since these studies were performed (see Yabusaki et al. 2015 for more discussion). Despite this "warning," the low recharge rates expected for the IDF subsurface environment and the mass of cementitious secondary wastes to be buried are similar to those modeled by Criscenti et al. (1996); as a result, the IDF near-field Cast Stone leachate $\mathrm{pH}$ might be expected to remain caustic for millennia. In the example above with the barrel filled one-third with cement, at an IDF recharge rate of $0.35 \mathrm{~cm} / \mathrm{yr}$, it would take more than 55,000 years for the $\mathrm{pH}$ to drop below 10. This hypothesis is also offered by the saltstone PA documents for the more saturated SRS site. Although the environmental conditions at the SRS are much different from those at Hanford (Savannah River has a nominal infiltration rate through a degraded closure cap of $31.6 \mathrm{~cm} / \mathrm{yr}$ (SRR CWDA 2014), whereas Hanford will have a post-design infiltration rate of $0.35 \mathrm{~cm} / \mathrm{yr}^{1}$ ), it has been shown in the FY2014 Special Analysis for the Saltstone Disposal Facility at the SRS (SRR CWDA 2014), that the transition from the high pH buffered by CSH to the lower $\mathrm{pH}$ buffered by calcite occurs between approximately 24,000 years for Saltstone Disposal Unit (SDU) 4 and >100,000 years for SDU 1 and SDUs that have diameters greater than 150 feet. In the SRS saltstone PA (SRR CWDA 2009), the source term release of contaminants of concern are based on both the degradation of the waste-form mineral forms from pore volume exchanges modeled using Geochemist Workbench ${ }^{\circledR}$ Release 6, incorporating $E_{h}$ effects on technetium, and a hypothetically degraded saltstone condition. Degraded saltstone is assumed to take the form of cracked grout, and has been modeled by increasing its hydraulic conductivity and modifying the characteristic curves.

Another parameter that can vary significantly in cement pore water and can influence contaminant release potential is the pore water redox potential, $E_{h}$. The major constituents that can influence the $E_{h}$ of cement pore fluids are the sulfur and iron contained in compounds found in the BFS. For details, the reader is referred to the discussions on this topic in Angus and Glasser (1985), Atkins and Glasser (1992), Serne and Westsik (2011), Um et al (2015), and references contained therein. The $E_{h}$ values of the disposal facility may also be controlled by the corrosion of iron containers (Ewart et al. 1988).

In summary, fresh cement/concrete, grout, and Cast Stone waste forms made with caustic and highly saline liquid wastes are highly reactive assemblages of solids that evolve over time. The extent of reaction and length of time required to significantly alter the waste form matrix will be a function of the amount and composition of infiltrating liquid passing through the disposal facility over time.

\footnotetext{
${ }^{1}$ Technical Guidance Document for Tank Closure Environmental Impact Statement Vadose Zone and Groundwater Revised Analyses, Revision 0, March 25, 2005. United States Department of Energy.
} 


\subsection{Release Modeling from Cementitious Waste Forms}

The framework for modeling the long-term performance of vitrified waste (McGrail et al. 2000) is based on a mechanism in which matrix hydrolysis and contaminant release are controlled by the rate at which chemical bonds are broken. While similar arguments can be made regarding the importance of modeling chemical reactions and transport in cement pore waters (Bacon et al. 2002), with cementitious waste forms, a physical model of contaminant diffusion and advective transport has been almost universally adopted (CBP 2009a,b, Yabusaki et al. 2015; Serne and Westsik 2011). In the absence of advective forces and with intact waste forms, contaminant release is generally considered a diffusioncontrolled process. Empirical effective diffusion coefficients measured in short-term laboratory experiments are widely used to model the long-term performance of cementitious waste forms (Albenesius 2001). These short-term laboratory diffusion measurement procedures have changed little since the International Atomic Energy Agency (IAEA) method was proposed by Hespe (1971) over 40 years ago. The effective diffusion coefficients measured for each contaminant are used for diffusion-controlled transport analysis.

It should be noted that other mechanisms of cementitious waste-form degradation and contaminant release are being considered and incorporated in the saltstone PA; for example, solubility-controlled release of technetium under reducing conditions, sulfate attack, carbonation, technetium desorption in oxidizing conditions, and redox capacity reduction through oxygen influx (SRR CWDA 2014).

Diffusional release of species from cementitious waste forms, such as LSW grout or Cast Stone, is best treated as a combination of transport impacted by physical and chemical processes. The discussion that follows is adapted from Serne et al. (2015). Atkinson et al. (1986), Atkinson and Nickerson (1988) and van Brakel and Heertjes (1974) describe the relationships among the various diffusion coefficients from diffusion of an ion in dilute water, to the diffusion of the same ion through porous media, and finally diffusion of the same ion assuming that it chemically interacts with the porous media through reversible sorption reactions. The conceptual model is based on the fact that cementitious waste forms consist of a complex porous matrix, which restricts free diffusion via physical processes as well as being a chemically reactive solid, with additional diffusion constraints caused by chemical interactions. The chemical interactions can have important retarding effects on final transport (or release) rates. The intrinsic diffusion coefficient $\left(D_{i}\right)$ of each particular species through the porous media quantifies the physical constraints to diffusion, and conceptually depends on the tortuosity $(\tau)$, constrictivity $(\delta)$, and porosity $(\varepsilon)$ of the cementitious waste form. These three physical parameters, attributes of the porous media, influence the diffusion coefficient of a solute in dilute water, $D_{f}$, described by

$$
D_{i}=D_{f} \frac{\varepsilon \delta}{\tau^{2}} \equiv \frac{j}{-\partial c / \partial x}
$$

where $j$ is solute flux (defined as mass flow rate per unit total area) and $c$ is solute concentration in the aqueous phase. Equation 2.10 assumes saturated conditions.

Tortuosity and constrictivity are two dimensionless parameters that are not readily measured, but conceptually represent physical attributes of the porous media. Tortuosity relates to the fact that a diffusing species inside the porous media will have to travel a larger distance to reach the outer surface of the porous media because the complex solid structure impedes direct migration down the concentration gradient that the ion would follow if diffusing through a fluid. Figure 2.2 is a portrayal of the tortuosity 
concept; it is obvious in this conceptualization that tortuosity has a numerical value greater than 1 . Constrictivity, another dimensionless parameter, is viewed to depend on the ratio of the diameters of the smallest and largest pores in the porous media. The value of constrictivity is always less than 1 . Constrictivity is not defined for a single pore, but as the parameter of the entire pore space within the porous media being considered. One numerical conceptualization of constrictivity assumes that constrictivity is related to a relationship between the maximum, minimum and mean pore diameters (see Figure 2.3. In practice, while porosity can be measured, the constrictivity and tortuosity factors are often combined as a purely empirical single parameter to establish the effective diffusivities in porous media.

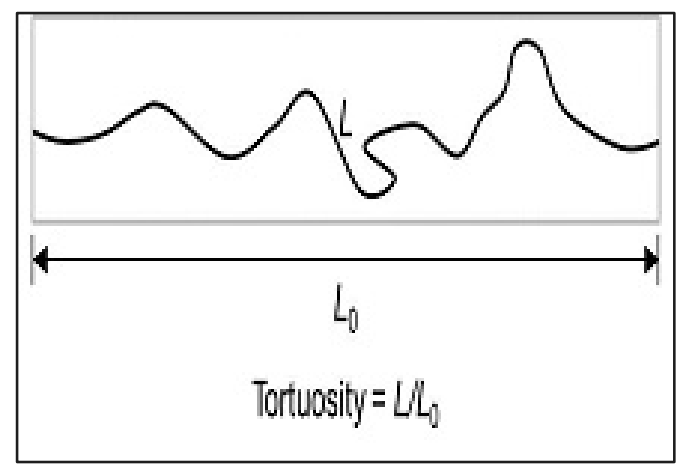

Figure 2.2. Conceptual Representation of Tortuosity $(\tau)$

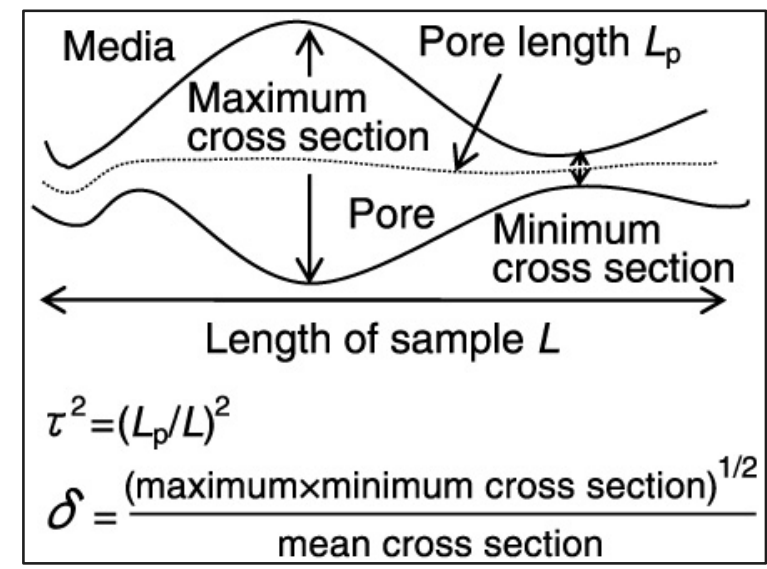

Figure 2.3. Conceptual Representation of Constrictivity $(\delta)^{2}$

Chemical interactions include ion exchange, precipitation, specific and irreversible adsorption, and each process may have fast or slow kinetics. The simplest process that is mathematically readily tractable is fully reversible ion exchange with fast kinetics that obeys a linear isotherm. This simple chemical process gives rise to the following equation:

$$
D_{\text {eff }}=\frac{D_{i}}{\alpha}
$$

where the modified diffusion coefficient is called the effective diffusion coefficient, $D_{\text {eff }}{ }^{3}$, and is related to the intrinsic diffusion coefficient for the physically constrained porous media by a chemical capacity factor, $\alpha$.

\footnotetext{
${ }^{2}$ Figure taken from Takahashi et al. 2009.
} 
The chemical capacity factor is the ratio of the moles of contaminant per unit volume of watersaturated solid $\left(\mathrm{C}_{\mathrm{s}}\right)$ to the moles per unit volume of contaminant in the liquid, $\mathrm{C}_{\mathrm{L}}$. The chemical capacity factor for the simple conceptual model for reversible sorption is related to the $K_{d}(\mathrm{~mL} / \mathrm{g}$ ) by the following equation:

$$
\frac{\alpha}{\varepsilon}=1+\frac{\rho K_{d}}{\varepsilon}=R
$$

where $\rho$ is the dry bulk density of the porous solid waste form. Here, R is the commonly used retardation factor. From equation 2.11,

or equivalently

$$
D_{\text {eff }}^{\text {sorbing }}=\frac{D_{\text {eff }}^{\text {non-sorbing }}}{R}
$$

$$
R=\frac{D_{\text {eff }}^{\text {non-sorbing }}}{D_{\text {eff }}^{\text {sorbing }}}
$$

This relationship requires fast and reversible chemical reaction processes and that sorption satisfies the linear isotherm constraint. Few chemical reactions for contaminants meet these requirements.

Regardless, this simple construct is often applied in quantifying the release of contaminants from cementitious waste forms because it allows one to separate the physical and chemical processes that control transport of contaminants. There are several experimental methods that one can use to measure the $K_{d}$ (and then compute $\alpha$ ) after measuring the porosity and bulk density of the waste form. Conversely, one can measure the effective diffusion coefficient using through-diffusion cells, penetration profiles of a contaminant into a solid porous medium, or out diffusion of contaminants (leaching tests), and then attempt to calculate $K_{d}$ values by comparing the $D_{\text {eff }}$ values for a companion species that is assumed to have a zero $K_{d}$ and is present in the same waste form. If one also has an independent or direct measure of the porosity of the cementitious waste form, then the measured $D_{\text {eff }}$ value for the non-sorbing constituent allows one to calculate the intrinsic $\left(D_{i}\right)$ coefficient for the specific waste form using equation 2.10 and the known porosity because equation 2.11 reduces to the porosity $(\varepsilon)$ when $K_{d}$ is zero.

For LSW grouts and Cast Stone, which contain the reductant BFS in their dry-blend mixes, we caution against assuming the measured $D_{\text {eff }}$ values for redox-sensitive COCs, such as Tc and Cr, represent chemical interactions controlled by reversible sorption. Thus, for cementitious waste forms containing mobile contaminants that are generally assumed to have $K_{d}$ values equal to zero, one can estimate a desorption $K_{d}$ using the logic just described wherein the $D_{\text {eff }}$ value for the mobile COC (often nitrate) is used in equations 2.10 and 2.11 along with independent measurements of porosity and dry bulk density to

${ }^{3}$ The term effective diffusion coefficient used in this report is called observed diffusion coefficient in EPA Method 1315 documents. ANSI/ANS16.1 uses the symbol D with no subscript and names D = effective diffusion coefficient. ASTM C1308 method uses the symbol $\mathrm{D}_{\mathrm{e}}$ and name effective diffusion coefficient. In some literature this parameter, the $\mathrm{D}_{\mathrm{e}}$ value in equations 2.9, 3.1, 3.2, and 3.3 is called apparent diffusion coefficient, $\mathrm{D}_{\mathrm{a}}$ (see for example Grathwohl (1998). All three names are equivalent and are "quantified" in standard leach tests by equations 3.1, 3.2, 3.3, and 3.4. 
calculate the cementitious waste form's inherent porous media $D_{i}$ value. This calculated $D_{i}$ value should be the same for all COCs in any given waste-form monolith for a specific mix/composition. Then by taking measured $D_{\text {eff }}$ for the chemically reactive COC such as Tc or Cr along with the calculated $D_{i}$ value for the waste-form monolith for the mix of interest, one can calculate the $\alpha$ ratio for the reactive COC using equation 2.10. From the independently measured values for porosity and dry bulk density, one can calculate the $K_{d}$ for the constituent. But as mentioned, the release of reduced species of Tc, Cr, $\mathrm{U}$, and other redox-sensitive COCs from cementitious waste forms containing BFS may not be controlled by reversible sorption processes unless the reductive capacity of the BFS is completely consumed under oxidizing conditions. Thus, despite the fact that the above logic can be used to calculate a $K_{d}$ for these COCs, their release may not be controlled by reversible desorption processes and therefore, predictions of future release based on the calculated desorption $K_{d}$ may not be accurate. If the controlling process for contaminant release is more likely solubility, then a solubility release conceptual model should be used to estimate long-term release of the contaminant of interest up to the time that the mass of the controlling solid has dissolved. After all the solid has dissolved, a sorption-desorption conceptual release model then may be appropriate to estimate contaminant release at longer times and at distances farther from the weathering waste form. As a final note, based on a review of Savannah River National Laboratory (SRNL) reports, it appears the SRNL-derived apparent diffusion coefficients used in their reports are the same as the PNNL "effective” diffusion coefficients found PNNL reports.

\subsection{Data Sources Included in the Review}

A cementitious waste form is being evaluated for solidifying the LSWs from the ETF. Most recently, WRPS has been funding work at PNNL and SRNL seeking a LSW grout for wastes after treatment in the ETF. This more recent work has focused on dry-blend mixes using hydrated lime to address high sulfate concentrations in the ETF-treated waste streams (Um et al. 2016, Cozzi et al. 2016). Their work investigated 16 different dry-blend mixes plus 2 replicates for a total of 18 tests. Most of the tests used a dry-blend mix with $20 \mathrm{wt} \%$ hydrated lime, $35 \mathrm{wt} \%$ OPC, and $45 \mathrm{wt} \%$ BFS. Also included were dryblend mixes with $20 \mathrm{wt} \%$ hydrated lime, $10 \mathrm{wt} \%$ OPC, and $70 \mathrm{wt} \%$ BFS; $20 \mathrm{wt} \%$ OPC, $35 \mathrm{wt} \%$ fly ash, and $45 \mathrm{wt} \%$ BFS; and one with $8 \mathrm{wt} \%$ OPC, $45 \mathrm{wt} \%$ fly ash, and $47 \mathrm{wt} \%$ BFS to provide a tie to the Cast Stone formulation work. Selected formulations also included Xypex (Admix C-500 from Xypex Chemical Corp.) as a filler to reduce porosity and Sn-treated apatite and $\mathrm{SnCl}_{2}$ as possible "getter" materials to reduce the release of technetium from the cured LSW grouts. The dry-blend components were sourced from Pacific Northwest suppliers.

The ETF currently treats aqueous wastes from the 242-A evaporator, leachates from the Environmental Restoration Disposal Facility (ERDF), and other miscellaneous Hanford liquid wastes. When the WTP comes on line, the ETF will also treat the aqueous wastes from WTP and leachates from the IDF. Therefore, PNNL and SRNL tests included simulants of the WTP secondary wastes, 242-A evaporator condensates, and ERDF leachates after treatment in the ETF. The ETF treatment includes a neutralization of the wastes with sulfuric acid, so the simulants are much higher in sulfate than the secondary waste simulants studied by Pierce et al. (2010), Sundaram et al. (2011), and Mattigod et al. (2011) discussed in the next paragraph. Examples of the WTP secondary waste simulants before and after treatment in ETF are provided in Appendix B.

Previous evaluations of cementitious waste forms have used WTP secondary waste simulants before treatment in ETF and a Cast Stone formulation. Pierce et al. (2010) demonstrated that Cast Stone with a 
dry-blend mix of $8 \mathrm{wt} \%$ OPC, $45 \mathrm{wt} \%$ fly ash, and $47 \mathrm{wt} \%$ BFS is a viable waste form for immobilization of WTP secondary wastes to be treated in the ETF. Sundaram et al. (2011) conducted additional work to develop and begin the optimization of Cast Stone for WTP LSWs simulants prior to their being sent for treatment at the ETF. Their work evaluated the performance of the Cast Stone formulation over a range of waste simulant compositions and concentrations, and confirmed the viability of Cast Stone as a waste form for the WTP secondary wastes. Subsequently, Mattigod et al. (2011) prepared Cast Stone specimens with WTP secondary waste simulants at $2 \mathrm{M}, 4 \mathrm{M}$, and $6 \mathrm{M}$ sodium concentrations to measure contaminant release rates. The WTP secondary waste simulants used in these testing programs included simulants for the caustic scrubber from LAW and evaporator condensates from the Pretreatment Facility. The waste simulants were based on secondary waste effluents from the WTP before treatment in the ETF.

The mix ratio, which is the ratio of the mass of free water in the liquid waste to the mass of dry blend in the mix, used in the recent LSW grout testing included values of 0.5 and 0.6.

The LSW grout and Cast Stone formulations were tested to demonstrate their ability to meet potential IDF waste-form performance criteria including

- free liquids per EPA Method 9095B, Paint Filter Liquids Test (EPA 2004)

- Land Disposal Requirements treatment standards per EPA Method 1311, Toxicity Characteristic Leaching Procedure (TCLP) (EPA 1999)

- compressive strength per ASTM C39/C39M-10, Standard Test Method for Compressive Strength of Cylindrical Concrete Specimens (ASTM C39/C39M-10). Compressive strengths are to be measured before and after thermal cycling per ASTM B553-79, Test Method for Thermal Cycling of Electroplated Plastics (ASTM B553-79) and after 90 days of water immersion.

- leachability for the COCs using

- American National Standards Institute/American Nuclear Society (ANSI/ANS) Standard 16.1, Measurement of the Leachability of Solidified Low-Level Radioactive Waste by a Short Term Test Procedure (ANSI/ANS 2003)

- ASTM C1308-08, Accelerated Leach Test for Diffusive Releases from Solidified Waste and a Computer Program to Model Diffusive, Fractional Leaching from Cylindrical Waste Forms (ASTM C1308-08)

- EPA Method 1315, Mass Transfer Rates of Constituents in Monolith or Compacted Granular Materials Using a Semi-Dynamic Tank Leaching Test (EPA 2013a)

- $\quad$ EPA Method 1313, Liquid-Solid Partitioning as a Function of Eluate pH using a Parallel Batch Procedure (EPA 2013b).

To support PA analyses, the PNNL and SRNL work with the LSW grouts included characterization with respect to porosity, hydraulic conductivity, water characteristic curves, ${ }^{99}$ Tc desorption $K_{d}$, and ${ }^{99} \mathrm{Tc}$ solubility measurements. Effective diffusivities using the EPA method were determined in a simulated VZPW in addition to the recommended deionized water (DIW).

Westsik et al. (2013) reported results of screening tests conducted on Cast Stone made with four Hanford LAW simulants to immobilize the wastes. These simulants were selected to represent a range of possible LAW compositions to be solidified in the Cast Stone waste form. The impact of key parameters, 
including expected ranges in waste composition, waste stream concentrations, sources of dry materials, and mix ratios of waste (free water) to dry blend, were evaluated. A statistically designed test matrix was used to evaluate the effects of these key parameters on the properties of the Cast Stone as it was initially prepared as well as after curing. The screening tests comprised 26 individual Cast Stone mixes selected through the statistical design. The statistical experimental design included two blocks. The first block of 12 mixes plus 2 replicates was selected to estimate the main effects among the study parameters. The second block of 10 mixes plus 2 replicates was selected to estimate the effects of some two-parameter interactions. One mix in Block 1 was replicated in Block 2. The specific parameters included in the statistically designed matrix were

- waste simulant composition

- a single-shell tank (SST) blend based on the analyses of saltcake from six SSTs

- $\quad$ an overall average LAW feed composition based on Hanford Tank Waste Operations Simulator (HTWOS) flow-sheet modeling

- a high-aluminum simulant based on HTWOS flow-sheet modeling

- a high-sulfate simulant based on HTWOS flow-sheet modeling.

- waste concentration expressed in terms of the sodium concentration in the wastes (5.0 M and 7.8 M $\mathrm{Na})$

- sources of dry materials for Cast Stone dry blend, also known as premix

- Class F fly ash source

○ fly ash from the Pacific Northwest—relatively high in calcium

○ fly ash from the Southeast (supplied by SRS)—relatively low in calcium

- Blast furnace slag

- Pacific Northwest source

○ Southeast source (supplied by SRS)

- $\quad$ OPC from the Pacific Northwest

- The mix ratios included 0.4 (based on previous Cast Stone secondary waste studies) and 0.6 (based on current processing experience with the Saltstone Processing Facility at the SRS) (Staub et al. 2010).

The ratio of cement to fly ash to BFS was held constant at the nominal Cast Stone mix ratio of 8:45:47 for all 26 mixes. The different combinations of simulants, Na concentrations, and mix ratios yielded waste loadings ranging from $9.5 \mathrm{wt} \%$ to $20.3 \mathrm{wt} \%$ total waste solids in the Cast Stone waste form.

Relevant measurements and testing that were conducted on cured Cast Stone monoliths including compressive strength, which was measured in triplicate, TCLP (Toxicity Characteristic Leaching Procedure, EPA Method 1311, [EPA 1999]), and EPA Method 1315 leaching tests on duplicate monoliths to determine effective diffusivity of key COCs. EPA 1315 diffusivity measurements were continued for durations beyond 600 days on selected monoliths from the screening tests (Serne et al. 2015). These extended tests also examined the effect of a VZPW on the measured effective diffusivities. 
Also included in this review are data on leachability index (LI) measurements (see equation 3.4 below) from Cast Stone formulations made with higher sodium concentrations (Fox et al. 2014). These data were converted to effective diffusivities for comparison. Additional $K_{d}$, physical property, and hydrologic data included in this review are data used to conduct the Saltstone Disposal Facility PA at the SRS (SRR CWDA 2009). Some of these data were updated in the FY 2014 Special Analysis for the Saltstone Disposal Facility at the SRS (SRR CWDA 2014). Reductive capacity data from Um et al. (2013) are included as well. In general, this data review is focused on the most recent LSW grout formulation work and Cast Stone data with secondary wastes and LAW simulants. It purposely excludes earlier work with non-relevant earlier flow-sheet concepts and grout formulations. Saltstone data are only included when data for LSW grout or Cast Stone are non-existent or very sparse.

\subsection{Contaminants of Focus}

Past risk assessments of the IDF include the tank closure and waste management environmental impact statement (DOE 2012), the 2003 risk assessment (Mann et al. 2003), and the 2001 ILAW PA (Mann et al. 2001). In each of these risk assessments, the key contaminants of concern for groundwater protection were identified as ${ }^{99} \mathrm{Tc},{ }^{129} \mathrm{I}$, chromium, uranium, and nitrate. Nitrate and nitrite are included in this data package because these species are thought to be practically non-sorbing and thus produce effective diffusion coefficients indicative of a non-reactive species. Comparison to effective diffusion coefficients for reactive species provides an indication of observed retardation for the latter. 


\title{
3.0 Review of Contaminant Release Data and Physical and Hydraulic Properties for Cast Stone
}

\begin{abstract}
Wastes intended for disposal in the IDF must meet requirements of DOE Order 435.1 (DOE 1999) and permit requirements established by the Washington State Department of Ecology. The IDF permit does not identify specific waste acceptance criteria (WAC) for solidified secondary wastes. It does require that "six months prior to IDF operations, Permittees shall submit to Ecology for review, approval, and incorporation into the permit, all WAC to address at a minimum, the following: physical/chemical criteria, liquids and liquid containing waste, land disposal restriction treatment standards and prohibitions, compatibility of waste with liner, gas generation, packaging, handling of packages, minimization of subsidence.”
\end{abstract}

IDF WAC have not been established for all wastes to be disposed of in the facility. Several draft WAC have been proposed, some limited to the ILAW glass waste form and a bulk vitrification waste form. Others have included criteria applicable to other waste forms as well (RPP 2005). Included are criteria with respect to free liquids, compliance with land disposal restrictions, compressive strength, and leachability.

\subsection{Measurements of Effective Diffusion Coefficients for Key Contaminants}

Historically, the ANSI/ANS 16.1 (ANSI/ANS 2003) test was used to estimate the effective diffusion coefficients for cementitious waste forms. Recently, the EPA introduced a new series of tests, with EPA Method 1315 (EPA 2013a) being the one now used to estimate the effective diffusion coefficient. Work performed earlier at Hanford on Cast Stone was reviewed, but because of the introduction of the new EPA methods and slightly different waste-form compositions, the earlier work is given less weight.

The effective diffusion coefficients measured by the EPA 1315 and ANSI/ANS 16.1 methods are calculated based on an assumption of diffusion from all surfaces of a waste form immersed in an infinite bath of leachant. The data calculations assume diffusion from a semi-infinite solid (Crank 1975), which is a reasonable assumption for a right circular cylinder as long at the amount of material leached is less than approximately $20 \%$ of the initial inventory. The resulting effective diffusivity is considered a lumped parameter that includes effects such as adsorption, solubility, tortuosity, and constrictivity. The EPA Method 1315 uses the following equation:

$$
D_{e f f}=\pi\left[\frac{M_{t_{i}}}{2 \rho C_{o}\left(\sqrt{t_{i}}-\sqrt{t_{i-1}}\right)}\right]^{2}
$$

where $\quad D_{\text {eff(i) }}=$ mean observed diffusivity of a specific constituent for leaching interval, $i\left(\mathrm{~m}^{2} / \mathrm{s}\right)$

$M_{t i}=$ mass released per unit area of the monolith during leaching interval $i\left(\mathrm{mg} / \mathrm{m}^{2}\right)$

$t_{i}=$ cumulative contact time after leaching interval, $i(\mathrm{~s})$

$t_{i-1}=$ cumulative contact time after leaching interval, $i-1$ (s)

$C_{0}=$ initial leachable content $(\mathrm{mg} / \mathrm{kg})$

$\rho=$ sample dry density $\left(\mathrm{kg} / \mathrm{m}^{3}\right)$.

The ANSI/ANS 16.1 method uses the following equation: 


$$
\mathrm{D}=\pi\left[\frac{\left(\mathrm{a}_{\mathrm{n}} / \mathrm{A}_{\mathrm{o}}\right)}{(\Delta \mathrm{t})_{\mathrm{n}}}\right]^{2}\left(\frac{\mathrm{V}}{\mathrm{S}}\right)^{2} \mathrm{~T}
$$

where $\mathrm{D}=$ effective diffusivity $\left(\mathrm{cm}^{2} / \mathrm{s}\right)$ during leach interval

$\mathrm{V}=$ volume of specimen $\left(\mathrm{cm}^{3}\right)$

$\mathrm{S}=$ geometric surface area of the specimen $\left(\mathrm{cm}^{2}\right)$

$\mathrm{T}=$ leaching time representing the "mean time" of leaching interval $=\left[1 / 2\left(\mathrm{t}_{\mathrm{n}}^{1 / 2}+\mathrm{t}_{\mathrm{n}-1} \mathrm{1}^{1 / 2}\right)\right]^{2}$

$\mathrm{a}_{\mathrm{n}}=$ quantity of an element released from the specimen during the leaching interval

$\mathrm{A}_{0}=$ Total quantity of an element in the specimen at the beginning of the first leaching interval

$\Delta \mathrm{t}_{\mathrm{n}}=$ duration of the $\mathrm{n}^{\text {th }}$ leaching interval (s)

ASTM International also has a method for determining diffusive releases from cylindrical waste forms, ASTM method C1308-08 is a short 11-day leach test and the effective diffusivity is calculated using the equation:

$$
D_{e}=\frac{\pi}{t_{n}}\left[\frac{\sum a_{n}}{A_{0}} \frac{V}{2 S}\right]^{2}
$$

where $\quad D_{\mathrm{e}}=$ effective diffusion coefficient of a specific constituent for cumulative leaching interval $n$

$\mathrm{t}_{\mathrm{n}}=$ cumulative time

$\mathrm{a}_{\mathrm{n}}=$ total amount of the species of interest released in all leaching intervals through time $t_{n}$

$\mathrm{A}_{0}=$ total quantity of an element in the specimen before leaching

$\sum \mathrm{a}_{\mathrm{n}} / \mathrm{A}_{0}=$ cumulative fraction leached during leaching interval $\mathrm{t}_{\mathrm{n}}$

$\mathrm{V}=$ volume of specimen

$\mathrm{S}=$ geometric surface area of the specimen

Unlike the ANS-16.1 and EPA 1315 methods, the ASTM 1308 method calculates a diffusion coefficient based on a cumulative release rather than an incremental release. It effectively calculates an average over the duration of the test. Equations (3.1) and (3.2) yield identical numerical values for the effective diffusivity. Mattigod et al. (2011) showed that the three methods provided comparable Tc effective diffusivity values.

Leaching controlled by molecular diffusion and possibly linear, instantaneous, sorption will produce cumulative leached mass vs. cumulative time data that plots as a straight-line with slope $=1 / 2$ on log-log coordinates. If that is not the case, then equations (3.1) through (3.3) cannot be used to estimate an effective diffusion coefficient.

The LI is sometimes reported for the effective diffusivity measurements. The LI is calculated using

$$
L I_{i}=-\log _{10}\left[D_{\text {eff(i) }}\left(\mathrm{cm}^{2} / \mathrm{s}\right)\right]
$$

Note that the units of $D_{\text {eff }}$ in equation (3.1) are square meter(s) per second, and the LI in equation (3.4) is based on units of square centimeter(s) per second $\left(\mathrm{cm}^{2} / \mathrm{s}\right)$.

Figure 3.1 illustrates typical diffusivity behavior that exhibits a rapid decline during the first few days of the leach test. This decline in $D_{\text {eff }}$ is speculated to be wash-off of the surface of the test specimens and generally is not included when reporting effective diffusivities. For constituents that have not leached 
more than $20 \%$ of the initial amount of material in the specimen, the effective diffusivities for each leach interval tend to level out after about 28 days. In this case, the calculated effective diffusivity for each leach interval beginning with the 28-day value is simply averaged to estimate the $D_{\text {eff }}$ for that component.

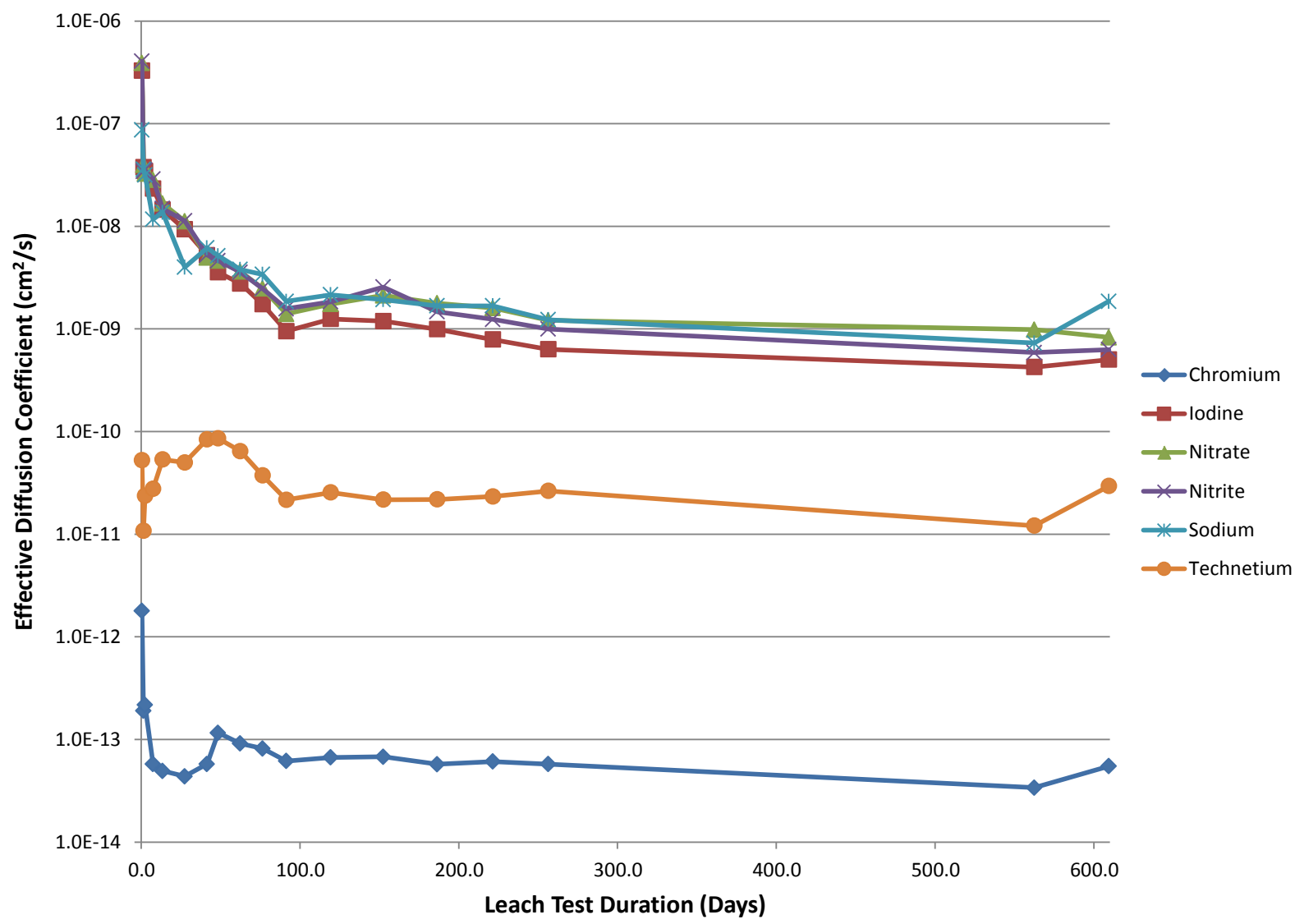

Figure 3.1. Effective Diffusivity for Selected Waste Components. Data from Mix 5 reported in Westsik et al. (2013) and Serne et al. (2015). Mix 5 represents an average Hanford LAW composition at 7.8 $\mathrm{M} \mathrm{Na}$ and showed mid-range performance in Tc retention of the 26 formulations tested.

\subsubsection{Effective Diffusion Coefficients - Technetium}

Um et al. (2016) measured effective diffusivities for Tc from LSW grouts using the EPA Method 1315. Eighteen formulations including two replicates were tested. The tests were conducted through 140 days and included both DIW and VZPW as leachants. For the 15 lime-based grouts, average Tc effective diffusivities in DIW over 28 through 140 days cumulative time leached ranged from $3.9 \times 10^{-15} \mathrm{~cm}^{2} / \mathrm{s}$ to $2.1 \times 10^{-12} \mathrm{~cm}^{2} / \mathrm{s}$ with an average of $4.9 \times 10^{-13} \mathrm{~cm}^{2} / \mathrm{s}$. In VZPW, the Tc diffusivities ranged from $3.2 \times$ $10^{-15} \mathrm{~cm}^{2} / \mathrm{s}$ to $3.1 \times 10^{-12} \mathrm{~cm}^{2} / \mathrm{s}$ with an average of $3.0 \times 10^{-13} \mathrm{~cm}^{2} / \mathrm{s}$. These results are shown in Figure 3.2. For the three fly-ash-based grouts including one Cast Stone formulation, average Tc effective diffusivities in DIW over 28 through 140 days cumulative time leached ranged from $5.7 \times 10^{-14} \mathrm{~cm}^{2} / \mathrm{s}$ to $1.7 \times 10^{-11} \mathrm{~cm}^{2} / \mathrm{s}$ with an average of $6.4 \times 10^{-12} \mathrm{~cm}^{2} / \mathrm{s}$. In VZPW, the effective diffusivities ranged from $3.6 \times 10^{-15} \mathrm{~cm}^{2} / \mathrm{s}$ to $1.0 \times 10^{-13} \mathrm{~cm}^{2} / \mathrm{s}$ with an average of $6.9 \times 10^{-14} \mathrm{~cm}^{2} / \mathrm{s}$. These results are shown in Figure 3.3. These data represent what Tc $D_{\text {eff }}$ values are available for lime- and fly-ash-based grouts for 
ETF-treated waste simulants. Other data available for fly-ash based (Cast Stone) mixes for other waste simulants (both WTP secondary and LAW) follow.

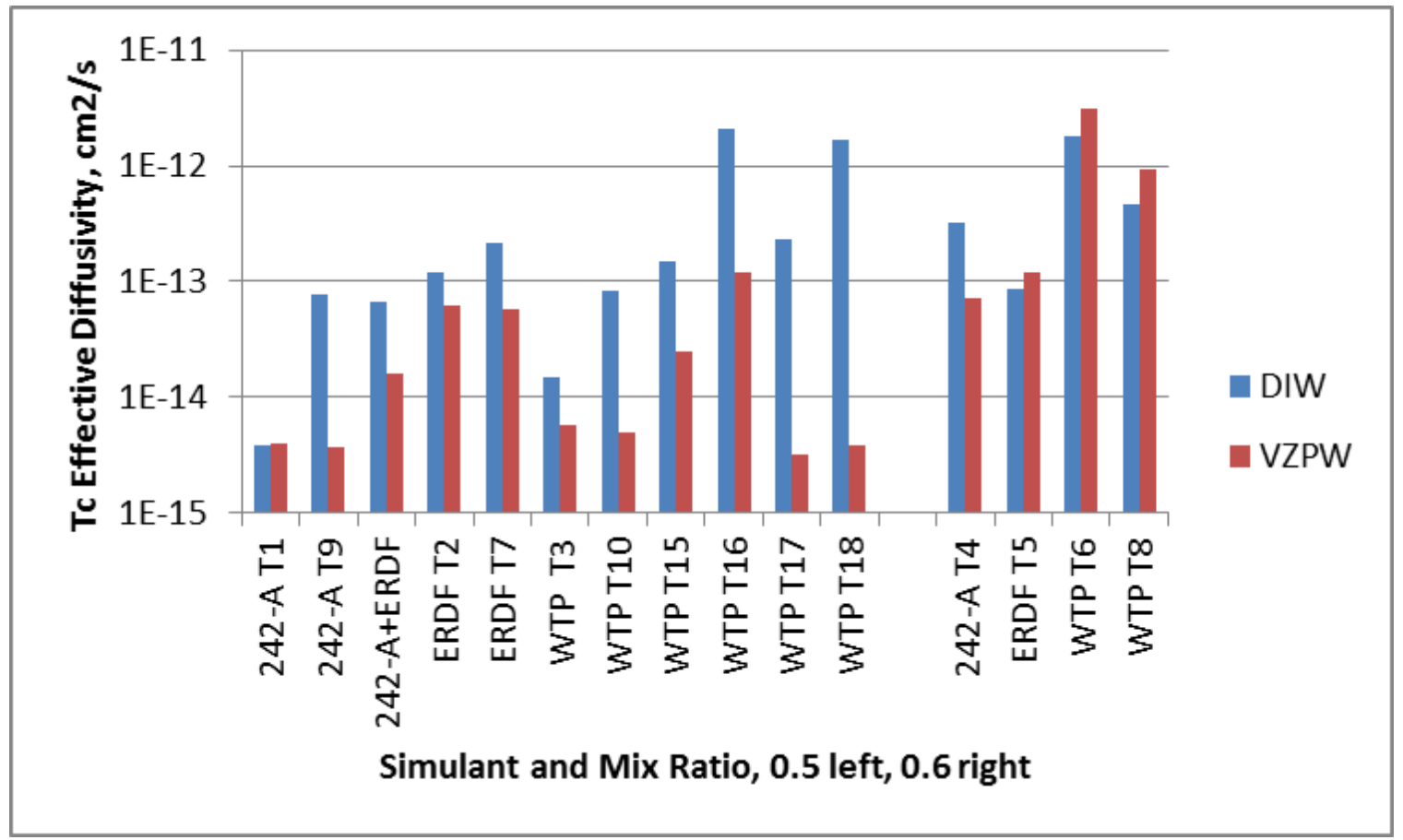

Figure 3.2. Tc Effective Diffusivities from LSW Grouts Averaged over 28 through 140 days Leaching (from Um et al. 2016)

Um et al. (2016) observed that release of ${ }^{99} \mathrm{Tc}$ from the lime-based grouts did not follow a pure diffusion trend. After 14-28 days, the slope of log cumulative mass leached versus log cumulative time was less than $0.5 \pm 0.15$ expected for a diffusion-controlled process. They speculate that some chemical reaction may be controlling the Tc release. See further discussion in Section 3.1.5.

Effective diffusivity values were determined for Tc (added as $\mathrm{TcO}_{4}^{-}$) in Cast Stone prepared with 2 M Na WTP secondary waste simulant by Mattigod et al. (2011) using the ANSI/ANS 16.1 leach test. The values exhibited rapid declines in leachability from initial values after one to two days. The diffusivities declined from initial values of $\sim 5 \times 10^{-9} \mathrm{~cm}^{2} / \mathrm{s}$ to $\sim 1 \times 10^{-9} \mathrm{~cm}^{2} / \mathrm{s}$ after the first two days. At the end of 90 days of leaching, Tc 49-d-to-91-d interval effective diffusivities decreased to approximately $2 \times 10^{-12} \mathrm{~cm}^{2} / \mathrm{s}$. Cumulative effective diffusivity (see equation 3.3) of Tc for the same waste form using the ASTM C1308 leach test was calculated based on the cumulative fraction leached and ranged from an initial value of $\sim 4 \times 10^{-9} \mathrm{~cm}^{2} / \mathrm{s}$ after 3 days to a final value of $\sim 1 \times 10^{-9} \mathrm{~cm}^{2} / \mathrm{s}$ after 11 days

Effective diffusivity results determined for Tc (added as $\mathrm{TcO}_{4}{ }^{-}$) in Cast Stone $2 \mathrm{M} \mathrm{Na}$, Cast Stone $4 \mathrm{M} \mathrm{Na}$, and Cast Stone $6 \mathrm{M}$ Na WTP secondary waste by Mattigod et al. (2011) using the EPA 1315 leach test indicated a rapid decline in Tc diffusivity after a full day of leaching; by the end of the 63 days, leaching had decreased by about three orders of magnitude. At the end of 63 days of leaching, the Cast Stone $2 \mathrm{M} \mathrm{Na}$, Cast Stone $4 \mathrm{M} \mathrm{Na}$, and Cast Stone $6 \mathrm{M}$ Na monoliths yielded Tc diffusivities that were $\sim 5 \times 10^{-12} \mathrm{~cm}^{2} / \mathrm{s}, \sim 1 \times 10^{-10} \mathrm{~cm}^{2} / \mathrm{s}$, and $\sim 6 \times 10^{-11} \mathrm{~cm}^{2} / \mathrm{s}$, respectively. These mixes were very lean with respect to available water (water-to-dry-mix ratio of 0.35 to 0.38 ) compared to later mixes and had 
workability issues so that there may not have been sufficient water for the hydration mixes. These simulants and formulations are not representative of current LSW grouts.

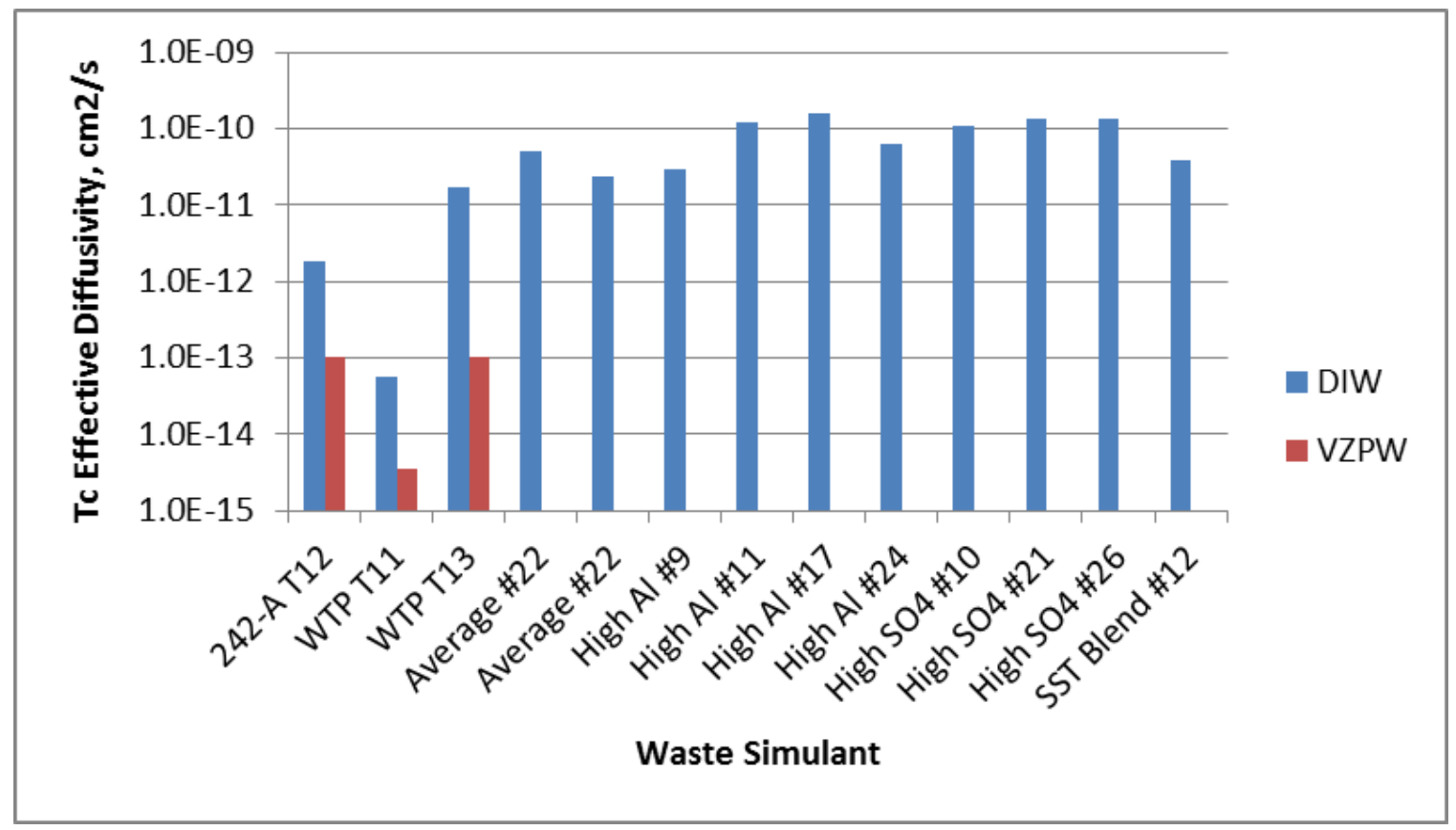

Figure 3.3. Tc Effective Diffusivities from 0.6 Mix Ratio Fly-Ash-Based Grouts and Cast Stone (from Westsik et al. 2013, Um et al. 2016)

Westsik et al. (2013) reported effective diffusivity results for Tc (added as $\mathrm{TcO}_{4}{ }^{-}$) from 24 individual Cast Stone mixes of four different LAW simulants using EPA Method 1315 and DIW as the leachant. According to Westsik et al. (2013), the interval-averaged diffusivities were calculated as follows: "For purposes of the statistical analyses of the screening test results, the effective diffusivities and LIs for the 28-, 42-, 49-, and 63-day intervals were averaged for each COC to calculate an average effective diffusivity and an average LI for each of the two duplicate samples of a given Cast Stone mix. Then, the average effective diffusivities and LI values for the two duplicates were used to calculate means and standard deviations.” Statistical analyses for the replicate samples included in the test matrix are provided in Appendix A (Table A.5). The leach tests were extended beyond the 63 days used in the statistical analyses in the screening test report to a total of 91 days. For Tc, effective diffusivity values averaged over 28 to 91 days ranged from $6.0 \times 10^{-12} \mathrm{~cm}^{2} / \mathrm{s}$ to $1.9 \times 10^{-10} \mathrm{~cm}^{2} / \mathrm{s}$ with an average of $7.0 \times 10^{-11} \mathrm{~cm}^{2} / \mathrm{s}$ for all 24 mixes. The results for 12 formulations at a mix ratio of 0.6 are shown in Figure 3.3.

Serne et al. (2015) extended the leach tests of selected samples from the work started by Westsik et al. (2013) to cumulative leach times between 604 and 609 days. As shown in Figure 3.1, the Tc effective diffusivities remained relatively constant over the entire time excluding the initial wash off. For the time from 28 through 604 or 609 days, the Tc effective diffusivities for the selected mixes ranged from $9.6 \times$ $10^{-12} \mathrm{~cm}^{2} / \mathrm{s}$ to $2.6 \times 10^{-10} \mathrm{~cm}^{2} / \mathrm{s}$ with an average of $1.1 \times 10^{-10} \mathrm{~cm}^{2} / \mathrm{s}$. Serne et al. also initiated additional EPA 1315 leach tests on Cast Stone monoliths from the screening tests that had been cured for between 207 and 214 days before testing. These archive samples were leached in both DIW and a VZPW. Through 427 days of leaching, the Tc effective diffusivities averaged over 28 through 427 days in DIW ranged from $8.0 \times 10^{-12} \mathrm{~cm}^{2} / \mathrm{s}$ to $3.0 \times 10^{-10} \mathrm{~cm}^{2} / \mathrm{s}$ with an average of $1.0 \times 10^{-10} \mathrm{~cm}^{2} / \mathrm{s}$. In the VZPW, the Tc effective diffusivities averaged over 28 through 427 days ranged from $6.8 \times 10^{-13} \mathrm{~cm}^{2} / \mathrm{s}$ to $2.3 \times 10^{-11}$ 
$\mathrm{cm}^{2} / \mathrm{s}$ with an average of $7.5 \times 10^{-12} \mathrm{~cm}^{2} / \mathrm{s}$. These results are shown in Figure 3.4 and Figure 3.5 at mix ratios of 0.4 and 0.6 , respectively. In the figures, DIW-91 refers to specimens cured for approximately 30 days and leached for 91 days, DIW-600 refers to the same specimens leached through 604 or 609 days, DIW-Arh refers to specimens cured for between 207 and 214 days before leaching in DIW, and VZPW-Arh refers to specimens cured for between 207 and 214 days before leaching in VZPW.

A summary of the Tc effective diffusivity data from Um et al. (2016), Serne et al. (2015), Westsik et al. (2013), and Mattigod et al. (2011) is provided in Appendix A.

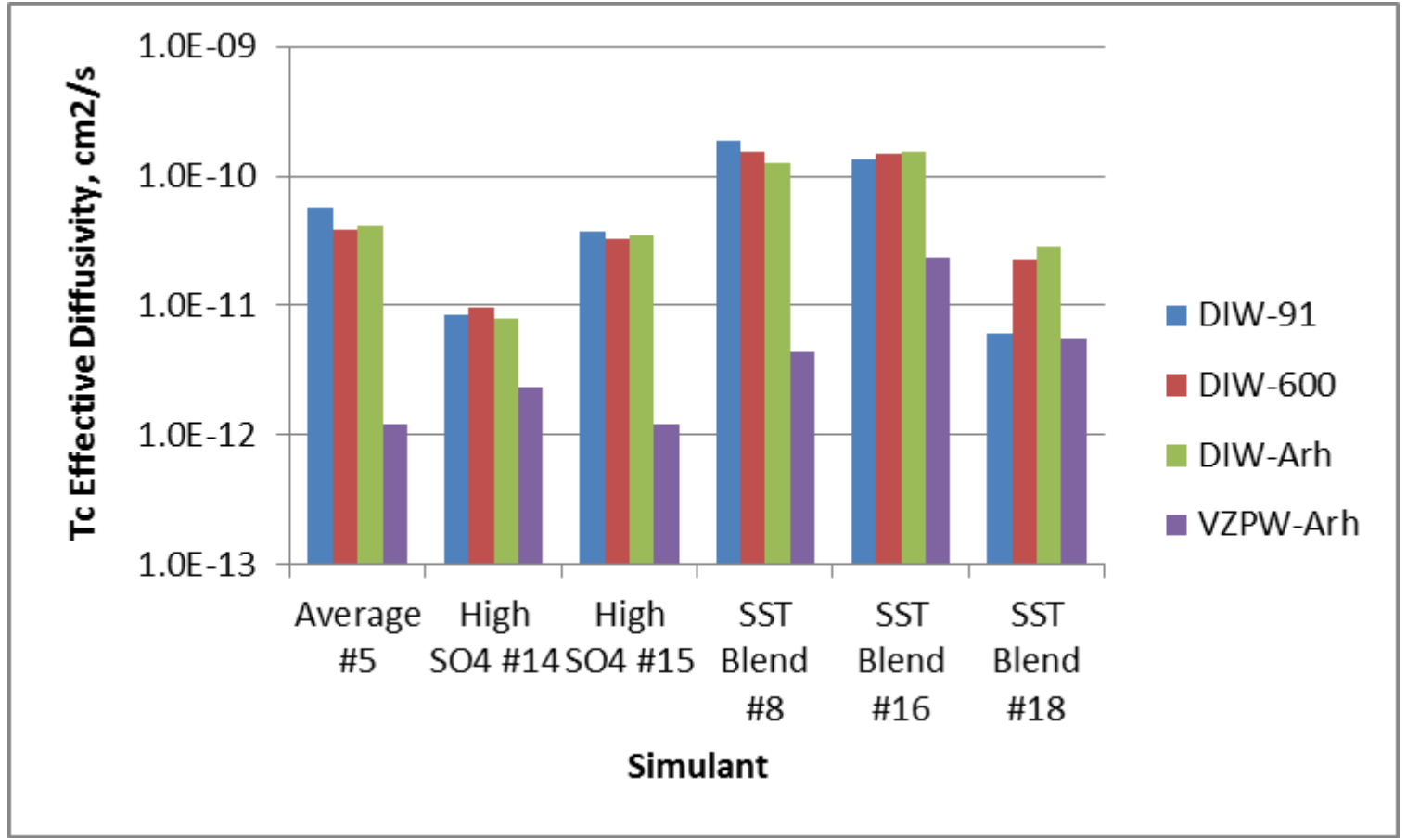

Figure 3.4. Tc Effective Diffusivities from Cast Stone LAW Extended Leach Testing Studies at a Mix Ratio of 0.4 (Serne et al. 2015) 


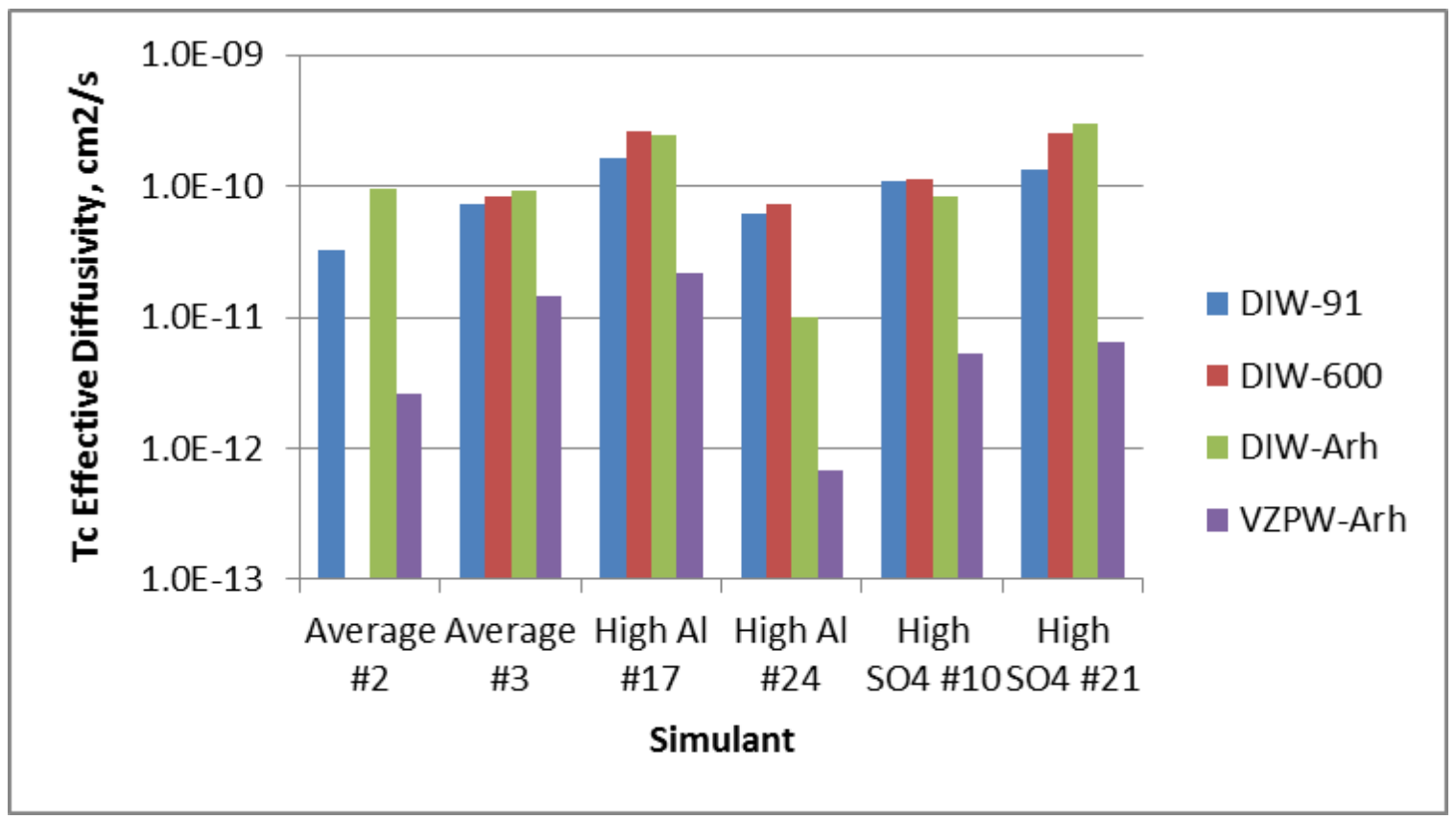

Figure 3.5. Tc Effective Diffusivities from Cast Stone LAW Extended Leach Testing Studies at a Mix Ratio of 0.6 (Serne et al. 2015)

\subsubsection{Effective Diffusion Coefficients - lodine}

Um et al. (2016) did not include iodine in their studies on ETF-treated simulants solidified in either lime- and fly-ash-based grouts. Thus the only data for I effective diffusivities come from studies using the Cast Stone dry blend.

Mattigod et al. (2011) determined effective diffusivity values for iodine added as iodide to Cast Stone 2 M Na WTP secondary waste simulant using the ANSI/ANS 16.1 leach test. During the first day of leaching of replicate monoliths, diffusivities ranged from $\sim 1 \times 10^{-7} \mathrm{~cm}^{2} / \mathrm{s}$ to $\sim 3 \times 10^{-7} \mathrm{~cm}^{2} / \mathrm{s}$. By the end of the 90 days, diffusivities decreased by approximately two orders of magnitude to an interval-averaged value of $<2 \times 10^{-9} \mathrm{~cm}^{2} / \mathrm{s}$. Results from the ASTM C1308 leach test are of limited value because after four days, the iodine concentrations in the leachates were below the detection limit.

Results of the EPA 1315 leach tests conducted by Mattigod et al. (2011) indicated that for the Cast Stone $2 \mathrm{M}$ Na and Cast Stone $4 \mathrm{M}$ Na WTP secondary waste monoliths, iodine interval-averaged diffusivities exhibited a gradual decrease over the course of the leaching period. After 42 days of leaching, the iodine concentrations for the Cast Stone $2 \mathrm{M}$ Na and Cast Stone $4 \mathrm{M}$ Na leachates were below the detection limit and only upper-bound diffusivities could be calculated. For the Cast Stone $6 \mathrm{M}$ Na samples, diffusivity values decreased by two orders of magnitude to $\sim 2 \times 10^{-9} \mathrm{~cm}^{2} / \mathrm{s}$ at end of the 49-day-to-63day leach interval.

The effective diffusivity values for 24 individual Cast Stone mixes prepared with four different LAW simulants reported by Westsik et al. (2013) using EPA Method 1315 for iodine averaged over 28 to 91 days ranged from $2.2 \times 10^{-9} \mathrm{~cm}^{2} / \mathrm{s}$ to $1.2 \times 10^{-8} \mathrm{~cm}^{2} / \mathrm{s}$. 
Fox et al. (2014) reported LI values determined using EPA Method 1315 for 20 Cast Stone samples made with HTWOS simulants that ranged from 7.0 M to 10.0 M in sodium concentration. Effective diffusivities were calculated in accordance with the EPA 1315 method and then the LIs were calculated. For this data package, the effective diffusivities were determined from the reported LI values and ranged from $1.0 \times 10^{-8} \mathrm{~cm}^{2} / \mathrm{s}$ to $5.0 \times 10^{-8} \mathrm{~cm}^{2} / \mathrm{s}$.

\subsubsection{Effective Diffusion Coefficients - Sodium}

Um et al. (2016) measured effective diffusivities for sodium from LSW grouts using the EPA 1315 method. Eighteen formulations including two replicates were tested. The leach tests were conducted through 140 days, and included both DIW and VZPW as leachants. For the 15 lime-based grouts, average Na effective diffusivities in DIW over 28 through 140 days ranged from $3.0 \times 10^{-10} \mathrm{~cm}^{2} / \mathrm{s}$ to $4.0 \times$ $10^{-9} \mathrm{~cm}^{2} / \mathrm{s}$, with an average of $1.8 \times 10^{-9} \mathrm{~cm}^{2} / \mathrm{s}$. In VZPW, the diffusivities ranged from $1.0 \times 10^{-9} \mathrm{~cm}^{2} / \mathrm{s}$ to $4.0 \times 10^{-8} \mathrm{~cm}^{2} / \mathrm{s}$ with an average of $7.4 \times 10^{-9} \mathrm{~cm}^{2} / \mathrm{s}$. These results are shown in Figure 3.6 in the left two blocks of columns. For the three fly-ash-based grouts including one Cast Stone formulation, average Na effective diffusivities in DIW over 28 through 140 days ranged from $6.7 \times 10^{-10} \mathrm{~cm}^{2} / \mathrm{s}$ to $2.1 \times 10^{-9}$ $\mathrm{cm}^{2} / \mathrm{s}$. In VZPW, the effective diffusivities ranged from $3.5 \times 10^{-9} \mathrm{~cm}^{2} / \mathrm{s}$ to $9.1 \times 10^{-9} \mathrm{~cm}^{2} / \mathrm{s}$. These results are also shown in Figure 3.6 in the right-most block of columns.

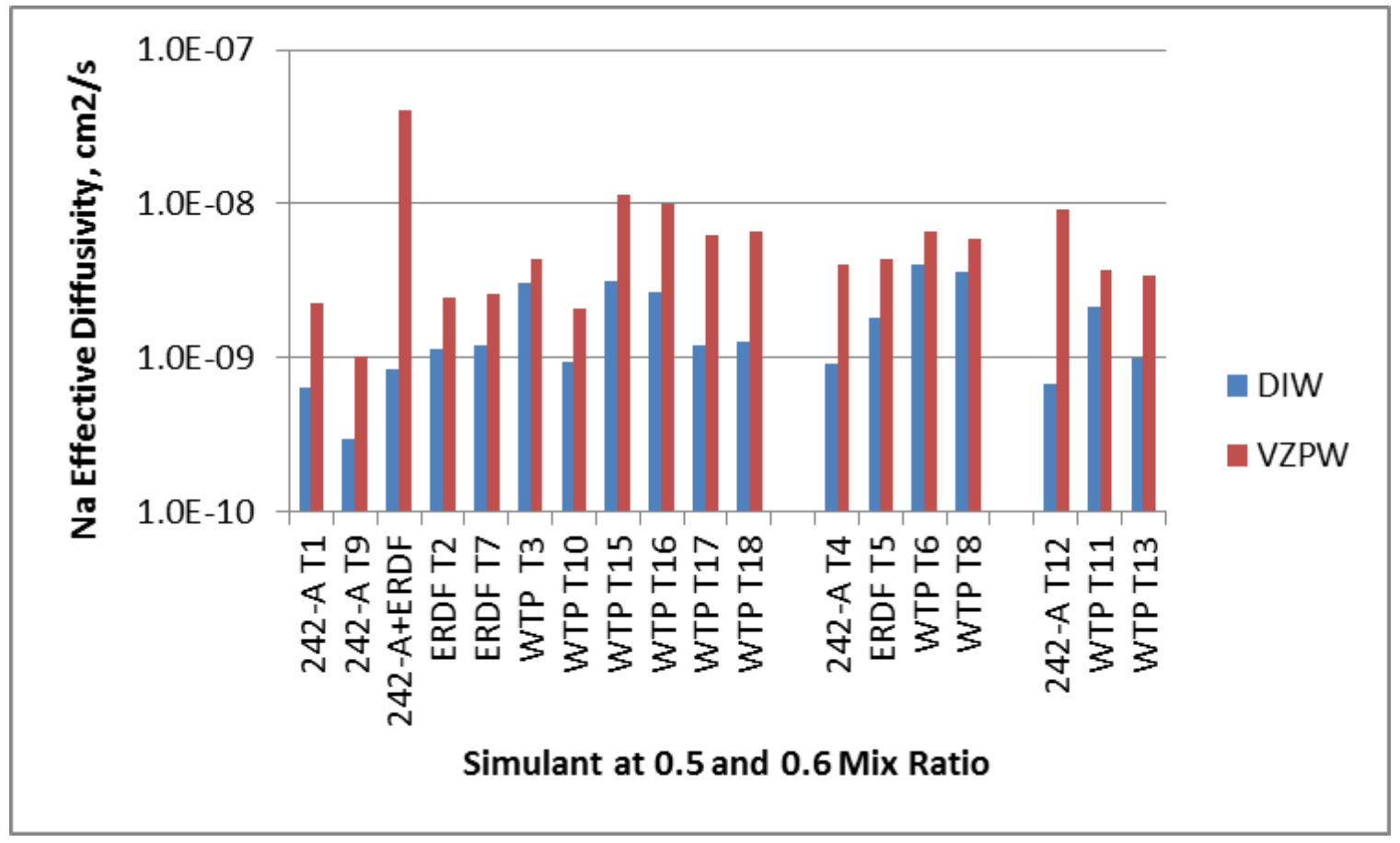

Figure 3.6. Na Effective Diffusivities from LSW Lime-Based and Fly-Ash-Based Grouts (from Um et al. 2016). Lime-based grouts are shown in the left two blocks of columns and the fly-ashbased grouts are shown in the right-most block of columns. 
The effective diffusivity values determined for sodium in Cast Stone prepared with a 2 M Na WTP secondary waste simulant by Mattigod et al. (2011) using the ANSI/ANS 16.1 leach test displayed rapid declines in leachability from initial values after one to two days. The interval-averaged diffusivities declined from initial values of $\sim 1.4 \times 10^{-8} \mathrm{~cm}^{2} / \mathrm{s}$ after 2 days to $\sim 8.6 \times 10^{-11} \mathrm{~cm}^{2} / \mathrm{s}$ at 91 days. The effective diffusivity of sodium for the same waste form using the ASTM C1308 leach test exhibited relatively constant cumulative diffusivity values over the 11-day test period. At the end of the 11-day test period, the average cumulative sodium diffusivity value was $\sim 8 \times 10^{-9} \mathrm{~cm}^{2} / \mathrm{s}$.

Interval-averaged effective diffusivity results determined for sodium in Cast Stone monoliths made with $2 \mathrm{M} \mathrm{Na}, 4 \mathrm{M} \mathrm{Na}$, and $6 \mathrm{M}$ Na WTP secondary waste simulants by Mattigod et al. (2011) using the EPA 1315 leach test indicated a steep decline in diffusivity after the first day of leaching, and by the end of the 63-day leach period, diffusivity had decreased by about two orders of magnitude. At 63 days, the interval-averaged diffusivity values for these three Cast Stone monoliths ranged from $\sim 1 \times 10^{-10} \mathrm{~cm}^{2} / \mathrm{s}$ to $\sim 9 \times 10^{-10} \mathrm{~cm}^{2} / \mathrm{s}$.

The interval-averaged effective diffusivity values for 24 individual Cast Stone mixes prepared with four different LAW simulants reported by Westsik et al. (2013) using EPA Method 1315 for sodium over 28 to 63 days ranged from to $2.0 \times 10^{-9} \mathrm{~cm}^{2} / \mathrm{s}$ to $1.0 \times 10^{-8} \mathrm{~cm}^{2} / \mathrm{s}$.

Fox et al. (2014) reported LI for 20 Cast Stone samples made with HTWOS simulants that ranged from 7.0 M to 10.0 M in sodium concentration. Duplicate samples were tested using EPA Method 1315 to obtain effective diffusivities for each leach interval. The leach index for each analyte was calculated using the ANS/ANSI 16.1 (2003) test procedure. The effective diffusivities calculated from the EPA 1315 method do not implement a correction when more than $20 \%$ of the analyte has been leached. The effective diffusivities determined from the reported LI values ranged from $7.9 \times 10^{-9} \mathrm{~cm}^{2} / \mathrm{s}$ to $2.5 \times 10^{-8} \mathrm{~cm}^{2} / \mathrm{s}$.

Note that for sodium and other more mobile species including iodine, nitrate, and nitrite, sufficient quantities of the material can leach from the test specimens such that the assumptions of a semi-infinite solid required in equation (3.1) are no longer valid. Figure 3.7 shows the cumulative fraction of Tc, Cr, $\mathrm{Na}$, nitrate, nitrite, and iodine from the extended leach tests on a LAW Cast Stone specimen through 609 days of testing. The curves for the more mobile species are bending over, while the curves for Tc and $\mathrm{Cr}$ remain linear for the duration of the testing. The ANS/ANSI 16.1 (2003) test procedure recommends a maximum of $20 \%$ cumulative fraction leached before correction factors need to be applied when calculating the effective diffusivities. For this data package, only test results through a maximum of 140 days are reported for Na, nitrate, nitrite, and iodine. 


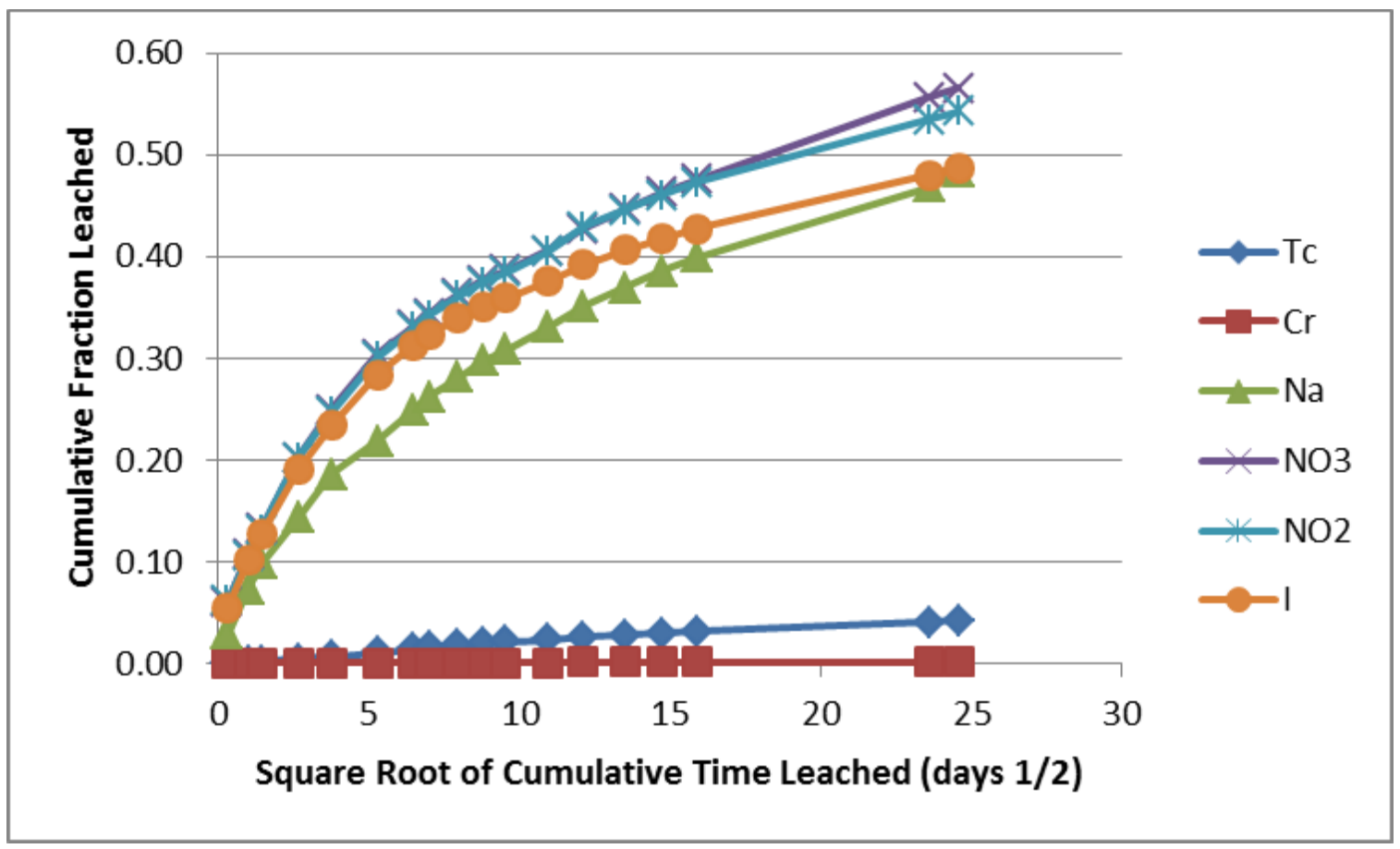

Figure 3.7. Cumulative Fraction Leached in Extended Leach Testing by Serne et al. (2015)

\subsubsection{Effective Diffusion Coefficients - Nitrate, Nitrite, Chromium, and Uranium}

Um et al. (2016) measured effective diffusivities for nitrate from LSW grouts using the EPA 1315 method. Fourteen formulations including two replicates were tested because nitrate was not included in 242-A simulant. The tests were conducted through 140 days and included both DIW and VZPW as leachants. For the 12 lime-based grouts, average nitrate effective diffusivities in DIW over 28 through 140 days ranged from $1.1 \times 10^{-10} \mathrm{~cm}^{2} / \mathrm{s}$ to $7.0 \times 10^{-10} \mathrm{~cm}^{2} / \mathrm{s}$, with an average of $3.4 \times 10^{-10} \mathrm{~cm}^{2} / \mathrm{s}$. In VZPW, the diffusivities ranged from $1.8 \times 10^{-10} \mathrm{~cm}^{2} / \mathrm{s}$ to $2.0 \times 10^{-8} \mathrm{~cm}^{2} / \mathrm{s}$, with an average of $6.1 \times 10^{-9}$ $\mathrm{cm}^{2} / \mathrm{s}$. Um et al. noted that many of the nitrate values in VZPW are based on estimated quantitation limit (EQL) values for $\mathrm{NO}_{3}{ }^{-}$because blank corrections results in zero or negative concentrations in the leachates. Thus the nitrate effective diffusivities in VZPW appear higher than in DIW. Nitrate diffusivities based on the EQLs were in the range of $2 \times 10^{-9}$ to $\mathrm{cm}^{2} / \mathrm{s}$ to $2.0 \times 10^{-8} \mathrm{~cm}^{2} / \mathrm{s}$. Based on measured concentrations, they ranged from $1.8 \times 10^{-10} \mathrm{~cm}^{2} / \mathrm{s}$ to $9.9 \times 10^{-10} \mathrm{~cm}^{2} / \mathrm{s}$. The nitrate effective diffusivities in VZPW based on the EQLs should be considered upper bounds with the actual effective diffusivities lower. The upper bounds are not considered representative. The measured nitrate results are shown in Figure 3.8 in the left two blocks of columns. For the two fly-ash-based grouts including one Cast Stone formulation, average nitrate effective diffusivities in DIW over 28 through 140 days ranged from $2.1 \times 10^{-10} \mathrm{~cm}^{2} / \mathrm{s}$ to $7.7 \times 10^{-10} \mathrm{~cm}^{2} / \mathrm{s}$. In VZPW, the effective diffusivities ranged from $2.1 \times 10^{-10}$ $\mathrm{cm}^{2} / \mathrm{s}$ to $3.2 \times 10^{-10} \mathrm{~cm}^{2} / \mathrm{s}$. These results are also shown in Figure 3.8 in the right-most block of columns. Nitrites were not included in the LSW simulants used by Um et al. (2016), and therefore, no effective diffusivities for nitrite were reported.

For both nitrate and nitrite, effective diffusivity values for 24 individual Cast Stone mixes prepared with four different LAW simulants reported by Westsik et al. (2013) using EPA Method 1315 averaged over 28 to 63 days ranged from $2.4 \times 10^{-9} \mathrm{~cm}^{2} / \mathrm{s}$ to $1.5 \times 10^{-8} \mathrm{~cm}^{2} / \mathrm{s}$. For chromium, the range was 
$8.0 \times 10^{-15} \mathrm{~cm}^{2} / \mathrm{s}$ to $1.0 \times 10^{-12} \mathrm{~cm}^{2} / \mathrm{s}$. For uranium, only five of the 24 samples had measurable uranium concentrations in the leachates. This is likely due to formation of uranium phases with low solubility (see Section 3.4). For these samples, the range in uranium interval-averaged diffusivities was $1.1 \times 10^{-16} \mathrm{~cm}^{2} / \mathrm{s}$ to $6.0 \times 10^{-16} \mathrm{~cm}^{2} / \mathrm{s}$. Mattigod et al. (2011) did not measure diffusion coefficients for these components.

Fox et al. (2014) reported LI values determined using EPA Method 1315 for 20 Cast Stone samples made with HTWOS simulants that ranged from 7.0 M to $10.0 \mathrm{M}$ in sodium concentration. The effective diffusivities for nitrate determined from the reported LI values ranged from $7.9 \times 10^{-9} \mathrm{~cm}^{2} / \mathrm{s}$ to $4.0 \times 10^{-8} \mathrm{~cm}^{2} / \mathrm{s}$. For nitrite, the range was from to $6.3 \times 10^{-9} \mathrm{~cm}^{2} / \mathrm{s}$ to $4.0 \times 10^{-8} \mathrm{~cm}^{2} / \mathrm{s}$. For chromium, the values were all $<2 \times 10^{-11} \mathrm{~cm}^{2} / \mathrm{s}$.

\subsubsection{Waste-Form Formulation Effects on $D_{\text {eff }}$}

A specific cementitious waste form formulation for solidification of ETF-treated wastes is under development. Early work focused on cement/fly ash/BFS formulations based on the Cast Stone formulation that was evaluated for supplemental immobilization to provide the necessary capacity for solidification of Hanford LAW. Most recent work has focused on lime/cement/BFS dry-blend formulations to address the sulfate addition to the wastes through the ETF treatment flow sheet (Um et al. 2016, Cozzi et al. 2016). The new hydrated lime-based LSW grouts show significant improvement in reducing the Tc effective diffusivities. In DIW leachants, the Tc effective diffusivities for the LSW grouts are a least an order of magnitude lower than for Cast Stone formulations made with the same ETF waste simulant.

Um et al. (2016) observed differences in the Tc releases from the hydrated lime LSW grouts and the fly-ash based Cast Stone formulation. Tc releases from the Cast Stone appeared to be diffusion controlled; at plot of log cumulative Tc leached versus log cumulative time was linear with a slope of 0.4 (within acceptable limit of $0.5 \pm 0.15$ per EPA 1315 method) for the duration of the test. For the LSW grouts, Tc releases appeared to be controlled by a diffusion process coupled with a chemical process specific to Tc. The log-log plot of cumulative Tc released versus cumulative time showed a linear slope of $\sim 0.5$ for the first 14 days followed by a much lower slope for the remaining 140 days of the test. See the figures in Appendix A of this data package. Nitrate and sodium releases from the LSW grouts showed good diffusion behavior. Although the mechanism of the Tc behavior in the LSW grouts is unknown, Um et al. (2016) speculate that there is an additional chemical process(es) that is controlling the Tc release. Chemical reactions that might slow the release of Tc could be (1) Tc incorporation into ettringite in either the pre-leached cured grout or a newly formed ettringite from transformation of portlandite during the active leaching stage, (2) ion exchange between Tc and sulfate in ettringite, (3) Tc removal by continuous and slow hydration reactions in the hydrated lime-based grouts, or (4) continuous slow Tc reduction (or incorporation to mineral phase) by slow dissolution of BFS. All these possible scenarios will be tested in a future task to understand ${ }^{99}$ Tc releases from the hydrated lime-based grout.

The statistical analyses in Westsik et al. (2013) indicated that the source of BFS has an impact on Tc effective diffusion coefficients for the LAW wastes studied. The Cast Stone specimens prepared with the Northwest-sourced BFS had statistically higher effective diffusivities than those prepared with the southeastern-sourced BFS. Um et al. (2016) used the Northwest-sourced BFS, so the results should be considered conservative should some effort be made in the future to use a southeastern-sourced BFS in a lime/BFS/cement dry blend. 
Investigative work has been done to evaluate the potential for improving the retention of Tc though the addition of getter materials to reduce $\mathrm{Tc}(\mathrm{VII})$ to the $\mathrm{Tc}(\mathrm{IV})$ oxidation state, which is less mobile in the environment (Qafoku et al. 2015, Neeway et al. 2015, Asmussen et al. 2015). In batch contact tests with getters added to DIW and LAW waste simulants spiked with Tc and iodine, Asmussen et al. (2015) showed that the getters were effective in reducing the concentrations of Tc and I in solutions, suggesting that there are some potential benefits for using Tc and I getters for LAW immobilization in Cast Stone. Two getter materials were evaluated by Um et al. (2016). At $\sim 1 \mathrm{wt} \%$ getter addition, the benefits of the getters were not as pronounced as the effects of the change to using the lime-based grout formulation. The work on the application of getters to improve the retention of Tc and I in cementitious waste forms is ongoing.

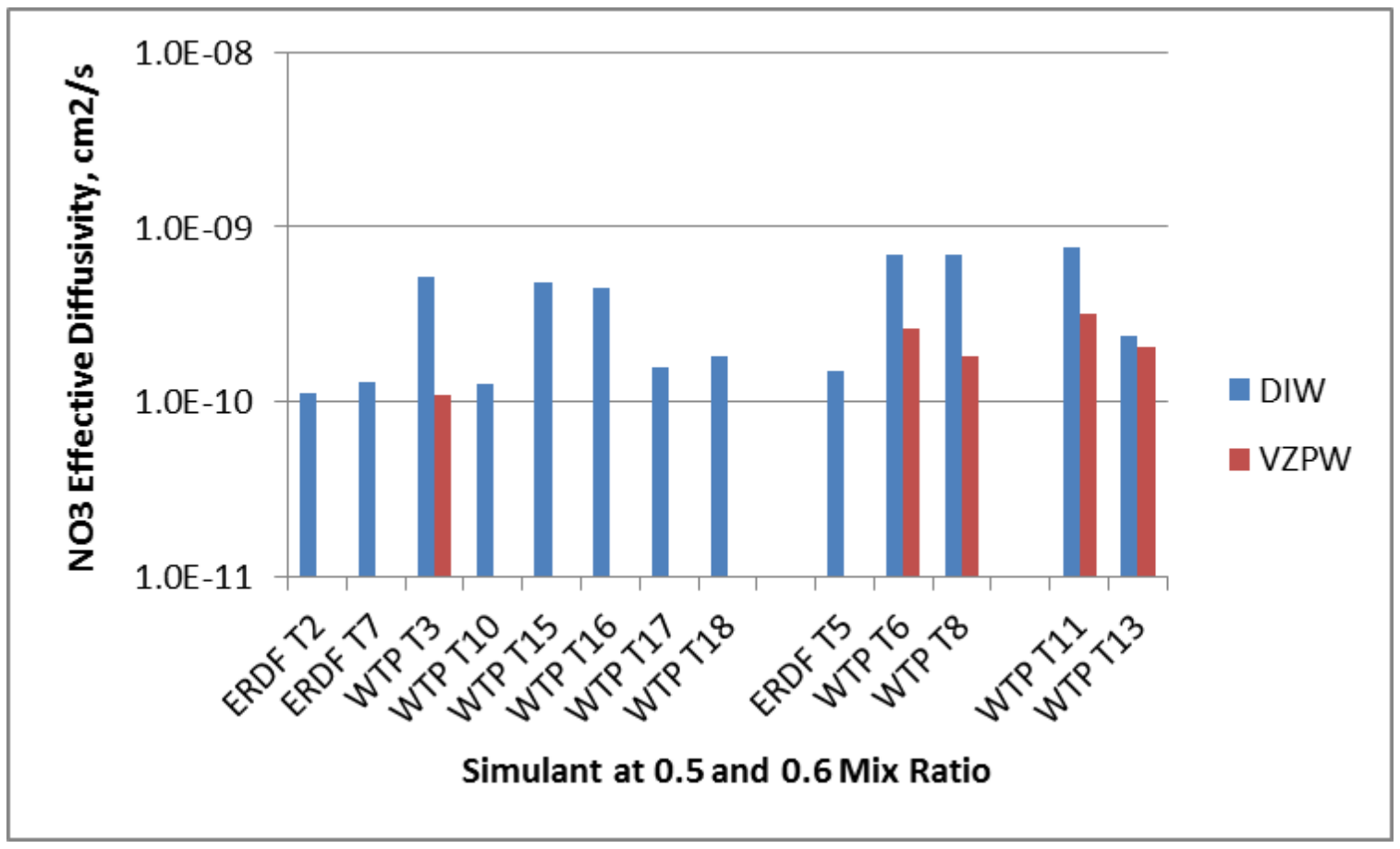

Figure 3.8. Nitrate Effective Diffusivities from LSW Lime-Based and Fly-Ash-Based Grouts (from Um et al. 2016). Most of the nitrate $D_{\text {eff }}$ in VZPW appear high because they are based on EQL values and are not shown in the figure. Lime-based grouts are shown in the left two blocks of columns and the fly-ash-based grouts are shown in the right-most block of columns.

\subsubsection{Effect of Waste Composition on $D_{\text {eff }}$}

The work of Um et al. (2016) and Westsik et al. (2013) and Serne et al. (2015) included a number of different waste simulants representative of the range of aqueous ETF-treated secondary wastes and LAW wastes, respectively to be solidified in cementitious waste forms. The work with the ETF-treated simulants did not show any specific trends, though a statistical analysis was not conducted. The work with the LAW simulants did include a statistical analysis that included the effects of the LAW simulant compositions. Westsik et al. (2013) determined that there were statistically significant effects of the different simulants on the LIs but effects of the differences were not as significant as those of other parameters, including BFS source and free water-to-dry blend mix ratio, on the measured leach rates. 


\subsubsection{Leachant Composition Effects on $D_{\text {eff }}$}

Serne et al. (2015) evaluated the effect of leachant composition on the measured effective diffusivities from LAW Cast Stone samples. Most waste-form leach tests are conducted with DIW as the leachant. However, DIW is not representative of the waters that a waste form will experience in the disposal environment. Therefore, Serne et al. also used a simulated Hanford VZPW as a leachant. They observed significantly lower effective diffusivities for all constituents leached in VZPW than leached in DIW; see, for example, Figure 3.4 and Figure 3.5. The diffusivities in the VZPW were typically at least an order of magnitude less than those in DIW. They attributed the difference to the formation of secondary precipitates on the surface and possibly in the interior of the Cast Stone monoliths. The precipitated material was identified by x-ray diffraction as a calcium carbonate phase (aragonite) and a magnesium hydroxide phase (brucite).

Asmussen et al. (2015) also observed a reduction in the Tc effective diffusivities in VZPW versus DIW. They did not observe a reduction in the iodine effective diffusivity in the VZPW. Um et al. (2016) saw similar effects on the Tc effective diffusivities in their work with ETF-treated wastes, though there appears to be a formulation effect, with the reduction in effective diffusivities in VZPW relative to DIW not as evident with lime-based mixes prepared at a $0.6 \mathrm{mix}$ ratio (see Figure 3.2 and Figure 3.3). As discussed above, the impact of the VZPW on nitrate diffusivities in Um et al. (2016) is difficult to evaluate because blank corrections for the VZPW resulted in zero or negative concentrations such that EQLs were used in the effective diffusivity calculations.

\subsubsection{Effect of Cementitious Waste-Form Curing Time on $D_{\text {eff }}$}

Serne et al. (2015) also evaluated the effect of curing time on the measured effective diffusivities. During the development phase, most leach tests are conducted after a nominal 28-day curing time. Serne et al. initiated some leach tests on specimens that had been cured for between 207 and 214 days before starting the leach tests. Comparing just the average Tc effective diffusivities from 28 to 63 days, there is no identifiable trend with respect to effect of curing time. The average diffusivities are within a factor of three for eight of the $12 \mathrm{LAW}$ mixes and within a factor of 6.5 for two other LAW mixes.

\subsubsection{Previous Reviews of Effective Diffusion Coefficients}

Available data for saltstone were reviewed by Phifer et al. (2006). They recommended an effective diffusion coefficient of $5 \times 10^{-9} \mathrm{~cm}^{2} / \mathrm{s}$ for non-sorbing species. This value is in line with previously recommended values for the SRS saltstone PAs (Cook and Fowler 1992; Cook et al. 2002, 2005). Langton (1986) used a modified ANSI/ANS-16.1 method to measure a nitrate effective diffusion coefficient of $5 \times 10^{-9} \mathrm{~cm}^{2} / \mathrm{s}$ in slag-containing saltstone. This work was the basis for the adopted PA value (Cook and Fowler 1992). For Tc, the maximum effective diffusion coefficient measured was $6 \times 10^{-10} \mathrm{~cm}^{2} / \mathrm{s}$. This value is about an order of magnitude lower than the nitrate value, and indicated that the addition of BFS had reduced Tc to the less mobile Tc(IV) oxidation state. Oblath (1989) reported a value of $5 \times 10^{-9} \mathrm{~cm}^{2} / \mathrm{s}$ for nitrate using saltstone immersion tests, but also demonstrated that the effective diffusion coefficient did not decrease appreciably for unsaturated conditions until the saturation level dropped below $8 \%$. Based on these results, it was concluded that diffusion coefficients measured under saturated conditions were applicable to partially saturated conditions. 
Pabalan et al. (2009) conducted a review of literature and assessment of factors relevant to the performance of grouted systems for radioactive waste disposal. As part of this review, radionuclide release data from cement-based materials was discussed. In the review, site-specific data for the Idaho National Engineering Laboratory and the SRS were emphasized. Specific recommendations for effective diffusion coefficients were not made, but data were reviewed for Hanford grout waste forms made with various waste streams, including phosphate-sulfate liquid waste, cladding-removal liquid waste, doubleshell slurry feed waste from tank T-106 AN, and double-shell slurry feed waste. These earlier Hanford grout formulations used substantially different dry blend components and water to dry blend mix ratios. These effective diffusion coefficients were not included in this review because our focus is on more recent data on cementitious waste forms made with aqueous secondary waste and LAW.

\subsection{Recommended Values for Effective Diffusion Coefficients}

Based upon the data for effective diffusion coefficients reviewed in Section 3.1, recommended ranges for effective diffusion coefficients for guiding a diffusion-controlled release conceptual model if used in the IDF PA are presented in Table 3.1. For secondary waste, two ranges are presented representing two different grout formulations. For a lime-based LSW grout, the ranges are based on the results presented by Um et al. (2016) for measured effective diffusivities in DIW. For fly-ash-based cementitious waste forms including Cast Stone, the ranges are based the results presented by Um et al. For Cast Stone formulations based on LAW, the results are based on the range of values determined using EPA Method 1315 averaged over 28 to 63 and 28 to 91 days and reported by Westsik et al. (2013). These values are generally consistent with or conservative relative to those reported by Mattigod et al. (2011) for the contaminants that were measured for simulated WTP secondary waste. These values are considered to be reasonable estimates based upon the preponderance of the data reviewed.

The effective diffusion coefficients for $\mathrm{Cr}$ and $\mathrm{U}$ shown in Table 3.1 are very low compared to those for other key COPCs. The EPA method 1315 tests are not designed to elucidate the mechanisms controlling the release of contaminants. We can only hypothesize from geochemical principles that reduction processes sourced from the BFS have converted most of the chromate present in the waste simulants to insoluble $\mathrm{Cr}$ (III) solids. At this time we have no solid phase characterization of the $\mathrm{Cr}$ "speciation" in unleached or leached Cast Stone or hydrated-lime-based grout. Attempts to determine the valence state of the $\mathrm{Cr}$ in these waste forms have been unsuccessful using either X-ray absorption nearedge structure (XANES) or X-ray photoelectron spectroscopy (XPS) measurements despite the fact that Cr concentrations are relatively large compared to other contaminants such as Tc and I whose valence state distributions have been successfully determined by XANES. No valence state information for the COPCs listed in Table 3.1 has been successfully determined by XPS because of interference from sodium present at very high concentrations in most Hanford liquid wastes. 

Table 3.1. Recommended Range of Effective Diffusion Coefficients for Cast Stone for Secondary Waste and LAW Waste Simulants

\begin{tabular}{|c|c|c|c|c|c|c|c|c|c|}
\hline \multirow[b]{3}{*}{ Contaminant } & \multicolumn{9}{|c|}{ Effective Diffusion Coefficient $\left(\mathrm{cm}^{2} / \mathrm{s}\right)$} \\
\hline & \multicolumn{3}{|c|}{$\begin{array}{c}\text { Secondary Waste } \\
\text { Lime-Based Grout } \\
\text { (Based on Um et al. 2016) }\end{array}$} & \multicolumn{3}{|c|}{$\begin{array}{c}\text { Secondary Waste } \\
\text { Fly-Ash-Based } \\
\text { Cast Stone } \\
\text { (Based on Um et al. 2016) }\end{array}$} & \multicolumn{3}{|c|}{$\begin{array}{c}\text { LAW Waste } \\
\text { Cast Stone } \\
\text { (Based on Westsik et al. 2013) }\end{array}$} \\
\hline & Tests & Range & $\begin{array}{l}\text { Geometric } \\
\text { Average }^{(a)}\end{array}$ & Tests & Range & $\begin{array}{l}\text { Geometric } \\
\text { Average }^{(a)}\end{array}$ & Tests & Range & $\begin{array}{l}\text { Geometric } \\
\text { Average }^{(a)}\end{array}$ \\
\hline Technetium & 15 & $4.0 \times 10^{-15}-3.0 \times 10^{-12}$ & $1.8 \times 10^{-13}$ & 3 & $5.0 \times 10^{-14}-2.0 \times 10^{-11}$ & $1.3 \times 10^{-12}$ & 24 & $5.0 \times 10^{-12}--3.0 \times 10^{-10}$ & $5.3 \times 10^{-11}$ \\
\hline Iodine & - & $3.0 \times 10^{-10}-5.0 \times 10^{-9(b)}$ & - & - & $8.0 \times 10^{-10}-3.0 \times 10^{-9}$ & - & 24 & $2.0 \times 10^{-9}--2.0 \times 10^{-8}$ & $5.7 \times 10^{-9}$ \\
\hline Sodium & 15 & $3.0 \times 10^{-10}-5.0 \times 10^{-9}$ & $1.6 \times 10^{-9}$ & 3 & $8.0 \times 10^{-10}-3.0 \times 10^{-9}$ & $1.3 \times 10^{-9}$ & 24 & $2.0 \times 10^{-9}--2.0 \times 10^{-8}$ & $5.8 \times 10^{-9}$ \\
\hline Nitrate & 12 & $3.0 \times 10^{-11}-9.0 \times 10^{-10}$ & $2.5 \times 10^{-10}$ & 2 & $2.0 \times 10^{-10}-9.0 \times 10^{-10}$ & $4.8 \times 10^{-10}$ & 24 & $2.0 \times 10^{-9}--2.0 \times 10^{-8}$ & $6.1 \times 10^{-9}$ \\
\hline Nitrite & - & $3.0 \times 10^{-11}-9.0 \times 10^{-10(b)}$ & - & - & $2.0 \times 10^{-10}-9.0 \times 10^{-10}$ & - & 24 & $2.0 \times 10^{-9}--2.0 \times 10^{-8}$ & $6.0 \times 10^{-9}$ \\
\hline Chromium $^{(\mathrm{c})}$ & - & - & - & - & - & - & 24 & $7.0 \times 10^{-15}--1.0 \times 10^{-12}$ & $1.1 \times 10^{-13}$ \\
\hline Uranium $^{(\mathrm{d})}$ & - & - & - & - & - & - & 24 & $<6.0 \times 10^{-16}$ & - \\
\hline
\end{tabular}

(a) Geometric means based on diffusivities averaged over 28-63 days in the EPA-1315 test.

(b) Recommended values for effective diffusion coefficients for iodine from the lime-based secondary waste grouts are based on the effective diffusion coefficient measured for sodium and the assumption that nitrite and nitrate diffuse at the same rate.

(c) The effective diffusion coefficient range for Cr likely represents a combination of solubility-controlled release of a Cr(III) solid and reoxidation of the Cr(III) to $\mathrm{Cr}(\mathrm{VI})$. The EPA-1315 test have not been run long enough to show any significant deviation in the rate of "net" Cr diffusion release that would suggest that the $\mathrm{Cr}$ (III) solid has been totally dissolved or reoxidized, which would imply that all the internal reductive capacity in the waste form has been exhausted.

(d) The effective diffusion coefficient range for U may represents a combination of solubility-controlled release of a U(IV) solid and reoxidation of the U(IV) to U(VI). The EPA-1315 tests have not been run long enough to show any significant deviation in the rate of "net” U diffusion release that would suggest that the U(IV) solid has been totally dissolved or reoxidized, which would imply that all the internal reductive capacity in the waste form has been exhausted.

Further, there are insoluble U(VI) solids such as uranyl-oxyhydroxide phases that, over time, transform to uranyl-silicate phases and then ultimately to uranyl-phosphate phases as long as adequate phosphate is present. 

Thus our recommendation for future IDF PA modeling of $\mathrm{Cr}$ and $\mathrm{U}$ release from Cast Stone and hydrated-lime-based grouts is to use a solubility-controlled release model up until other calculations that address the length of time that it takes for invading oxygen to completely reoxidize the BFS (and any other reductants) within the waste form. Once the waste form has been fully reoxidized, either a diffusion-controlled or a desorption-controlled release model could be used. For the "early" times when solubility might be controlling release we recommend that the controlling solid for $\mathrm{Cr}$ be $\mathrm{Cr}(\mathrm{OH})_{3}$ and for $\mathrm{U}$ be $\mathrm{U}(\mathrm{IV})(\mathrm{OH})_{4}$. For the later stages after the waste form has been fully reoxidized if a diffusioncontrolled release model is chosen use an effective diffusion coefficient for one of the seemingly mobile compounds such as nitrate for both $\mathrm{Cr}$ and $\mathrm{U}$. If a desorption $K_{d}$ is chosen use the range of values shown in Table 3.2

Recent work by Langton (2014) indicates that the leachability of technetium in slag-based sodiumsalt waste forms such as Cast Stone may be greater in samples exposed to moist soil (representative of unsaturated vadose zone conditions) than that of samples submerged in DIW (the method typically used in tests to determine effective diffusion coefficients). The recommended Tc effective diffusivities in Table 3.1 are based on the DIW measured values. Actual effective diffusivities are expected to be lower in the disposal environment, as evidenced by the lower effective diffusivities measured in the VZPW leachant. The Langton et al. (2014) results are especially relevant to determining the time that it takes to fully reoxidize the Cast Stone and hydrated-lime-based grouts. That is, the time to fully reoxidize the waste forms is likely shorter in a partially moisture saturated burial environment than in a fully saturated environment. The Langton et al. (2014) results need further evaluation to determine whether there is a consistent relationship between residual reductive capacity and Tc release from Cast Stone and hydratedlime-based grouts, and whether residual reduction capacity normalized to initial reduction capacity has any relationship to the inferred rate of oxidation front penetration into a monolith based on short-term water extracts of thin sectioned monoliths as a function of distance from the exposed surface. In addition, physical factors such as saturation level should be tested for its impact on the Tc leachability.

\subsection{Cementitious Material $K_{d}$ Values for Key Contaminants}

Except for Tc, $K_{d}$ values are currently not available for cementitious waste forms such as Cast Stone. In lieu of more relevant data, recommended desorption $K_{d}$ values for modeling contaminant release from cementitious materials that were used in the SRS saltstone PA are presented here (SRR CWDA 2014) and from Krupka et al. (2004) for the 2005 IDF PA. These values for some of the more important components that will leach from Cast Stone as a function of chemical state are provided in Table 3.2. Consider these $K_{d}$ values to represent any and all retention processes by the cementitious waste form including sorption and solubility constraints. That is, these $K_{d} \mathrm{~s}$ should only be used when a solubility controlling conceptual model is not going to be used. If a solubility controlling conceptual model is going to be used it should take precedence over a desorption conceptual model and the $K_{d}$ values in Table 3.2 should not be used. That is, COC interactions with the cementitious waste form can be quantified in simple predictive models by only one conceptual model at any spatial and temporal "location;" ideally, the choice of which conceptual model to use should be based on geochemical principles, but often will be determined by data availability. A completely coupled chemical reaction network-hydrologic flow code could solve COC transport controlled simultaneously by several mechanisms/processes as long as local equilibrium was assumed and conservation of mass was maintained. However, the availability of the 
necessary input data for the chemical reaction network, especially for COCs, and for boundary conditions is severely lacking at this time (see Yabusaki et al. (2015) for more discussion).

Reduced Region II is the initial state of cementitious materials containing BFS. Under this condition, the material has a negative oxidation/reduction potential $\left(E_{h} \sim-400 \mathrm{mV}\right)$ and a high $\mathrm{pH}$ value $(\sim 12.5)$. For cementitious materials that do not contain BFS, the initial state is Oxidized Region II. For this case, the material has a positive $E_{h}(50-250 \mathrm{mV})$ and high $\mathrm{pH}(\sim 12.0)$ value. Oxidized Region III refers to cementitious material that has equilibrated with its surrounding environment and is in its final chemical condition. For this case, the material has a positive $E_{h}$ value $(>250 \mathrm{mV})$ and a lower $\mathrm{pH}$ value ( 8-9). Note that the SRS data is for an analogous waste form but the disposal environment is significantly different from the arid Hanford environment.

Table 3.2. Recommended Desorption $K_{d}(\mathrm{~mL} / \mathrm{g})$ Values for Cementitious Materials (from SRR CWDA 2014, Table 4.1-4)

\begin{tabular}{ccccc}
\hline Component & Reduced Region II & Oxidized Region II & Oxidized Region III & Reference \\
\hline Tc & Solubility Control & 0 to 0.5 & 0 to 0.5 & a \\
I & 0 to 9 & 0 to 15 & 0 to 4 & a \\
$\mathrm{NO}_{3}$ & 0 to $1^{(*)}$ & 0 to $1^{(*)}$ & 0 to 1 & b \\
$\mathrm{NO}_{2}$ & 0 to $1^{(*)}$ & 0 to $1^{(*)}$ & 0 to 1 & b \\
$\mathrm{Cr}$ & 1000 & 10 & 0 to 1 & a \\
$\mathrm{U}$ & 2500 & 1000 & 3 to 100 & $\mathrm{c}$ \\
\hline
\end{tabular}

(a) Kaplan (2010) and Hanford geochemist's expert opinion based on observed diffusivities in EPA 1315 tests.

(b) Krupka et al. (2004) and current Hanford geochemist's expert opinion

(c) Seaman and Kaplan (2010) and current Hanford geochemist's expert opinion

(*) Kaplan (2010) shows desorption $K d$ values of 10 for nitrate and nitrite for both reducing and oxidizing conditions in Region II. However, the recommended values were based on measurements for chloride and there are no actual measurements for nitrate or nitrite. Discussions with Kaplan indicate that 0 to 1 are better desorption $K d$ values to use. The DOE Technical Guidance Document (DOE 2005) gives a value of 0 for nitrate.

\subsection{1 $\quad{ }^{99} \mathrm{Tc}$ Desorption Distribution Coefficients $\left(K_{d} \mathbf{S}\right)$ and Apparent Solubility Values}

Um et al. (2016) measured desorption $K_{d}$ s for three LSW grout formulations including two with hydrated lime, OPC, and BFS and one with fly ash, OPC, and BFS. The $K_{d}$ S were measured for selected size fractions of crushed grout samples that had sorbed ${ }^{99} \mathrm{Tc}$ for 30 days under reducing conditions. Then the Tc-laden crushed grout was subjected to fresh leachant (saturated $\mathrm{Ca}(\mathrm{OH})_{2}$ contacted with unspiked crushed grout) that contained no Tc and after 7 and 30 days of contact under both reducing and oxidizing conditions, Tc desorption $K_{d}$ values were calculated. The results are shown in Table 3.3. Under oxidizing conditions ( $E_{h}>+100 \mathrm{mV}$ and $\mathrm{pH} \sim 12.5$ ), the recommended desorption $K_{d}$ is $24.0 \pm 5.4 \mathrm{~mL} / \mathrm{g}$. However, these ${ }^{99} \mathrm{Tc}$ desorption $K_{d}$ values should be used with care because the BFS in the grout might still have some reductive capacity. Under reducing conditions $\left(E_{h}=-400 \mathrm{mV}\right.$ and $\left.\mathrm{pH}=\sim 12.5\right)$, the measured Tc desorption $K_{d} S$ were $\sim 269 \mathrm{~mL} / \mathrm{g}$. For the adsorption tests conducted always under always 
Table 3.3. ${ }^{99}$ Tc Desorption Distribution Coefficients $\left(K_{d} s\right)$ and Solubility

\begin{tabular}{cccccccc}
\hline $\begin{array}{c}\text { Test } \\
\text { ID }\end{array}$ & Simulant & $\begin{array}{c}\text { Water } / \\
\text { Ratio }\end{array}$ & $\begin{array}{c}\text { Dry Blend Mix } \\
(\text { wt\% })\end{array}$ & $\begin{array}{c}\text { Dry Blend } \\
\text { Components }\end{array}$ & $\begin{array}{c}K_{d}, \\
\text { Oxidizing* } \\
(\mathrm{mL} / \mathrm{g})\end{array}$ & $\begin{array}{c}K_{d}, \\
\text { Reducing } \\
(\mathrm{mL} / \mathrm{g})\end{array}$ & $\begin{array}{c}\text { Solubility, } \\
\text { Reducing } \\
(\mathrm{M})\end{array}$ \\
\hline 3 & WTP & 0.5 & $20 \%, 35 \%, 45 \%$ & lime, OPC, BFS & 17.8 & 267 & $3.4 \times 10^{-9}$ \\
6 & WTP & 0.6 & $20 \%, 35 \%, 45 \%$ & lime, OPC, BFS & 28.0 & 275 & $4.3 \times 10^{-9}$ \\
11 & WTP & 0.6 & $20 \%, 35 \%, 45 \%$ & OPC, FA, BFS & 26.2 & 266 & $5.1 \times 10^{-9}$ \\
\hline \multicolumn{2}{c}{ Average } & - & - & - & 24.0 & 269 & $4.3 \times 10^{-9}$ \\
\hline
\end{tabular}

* Tc $\mathrm{K}_{\mathrm{d}}$ in oxidizing conditions was determined using a fresh grout where BFS still provided some reducing condition. Therefore these values are representative of transition condition between reduced region II and oxidized region II in Table 3.2.

reducing conditions, the measured $K_{d} \mathrm{~s}$ (both the adsorption phase and desorption phase) were the same ( $\sim 270 \mathrm{~mL} / \mathrm{g})$. The authors concluded that, under reducing conditions, the release of ${ }^{99} \mathrm{Tc}$ from disaggregated LSW grouts is more likely controlled by the solubility of a ${ }^{99} \mathrm{Tc}(\mathrm{IV})$-bearing solid phase in the grout and not by a desorption process.

\subsection{Solubility of Contaminant-Bearing Phases}

Although the diffusion mechanism has been used in previous PAs and risk assessments to describe contaminant release from cementitious waste forms at Hanford, it is likely that under certain circumstances, solubility constraints may control release of specific contaminants, such as Tc, Cr, and U. This would be particularly true under low-flow conditions. The impact of reduced solubility is manifested in leaching experiments as low effective diffusion coefficients. Lower leachability causes a lower effective diffusion coefficient. Recently, it has been demonstrated that under reducing conditions, Tc release from saltstone is controlled by $\mathrm{TcO}_{2} \bullet \mathrm{xH}_{2} \mathrm{O}$ solubility (Cantrell and Williams 2013). In a recent special analysis for the SRS Saltstone Disposal Facility PA (SRR CWDA 2014), solubility was used to describe Tc release in the Reduced Region II. The pore water concentration of Tc in saltstone has been estimated to be $1.0 \times 10^{-8} \mathrm{~mol} / \mathrm{L}$ based on the thermodynamic solubility of various Tc oxides calculated for an assumed pore water composition (SRR CWDA 2014). This approach assumes that pore-water chemistry remains constant during the time that the saltstone remains in a reduced redox state. A thermodynamic solubility approach could also be used to calculate the solubility of technetium phases in IDF buried secondary waste forms contacting pore water based upon the pore water's evolving composition. Conceptually, the IDF subsurface near-field within degraded waste forms might start with a reducing condition at the very beginning based on excess BFS and nearby metallic container. Then at some point, the invading pore water will likely exhaust the residual BFS and breached container's reductive capability and the Tc release could be bounded by kinetically controlled oxidation of the $\mathrm{TcO}_{2} \bullet \mathrm{xH}_{2} \mathrm{O}$ solid presumed to control Tc release during reducing conditions. After complete dissolution of the presumed $\mathrm{TcO}_{2} \bullet \mathrm{xH}_{2} \mathrm{O}$ solid, sorption-desorption processes for $\mathrm{Tc}(\mathrm{VII})$ aqueous species would control the fate of Tc in near-field pore water as well as far-field pore waters. At this time, we have no guidance on when near-field reductive capacity would be exhausted. Additional work is needed in this area.

The BFS added to saltstone will also reduce chromate $\left(\mathrm{CrO}_{4}{ }^{2-}\right)$ in the waste stream to the relatively insoluble $\mathrm{Cr}(\mathrm{OH})_{3}$ (Langton and Stefanko 2012; Langton et al. 2013). Results reported by Pabalan et al. 
(2012) suggest that uranium is immobilized within saltstone as a $\mathrm{CaUO}_{4}$ (calcium uranate) phase, which is highly insoluble. Note that this uranium compound has $\mathrm{U}$ in the +6 oxidation state, thus uranium is not reduced by the BFS. Wellman et al. (2007) reported that uranium precipitates in concrete---not containing BFS---pore fluid as insoluble uranyl-oxyhydroxide phases initially, and, over time, these phases transform to uranyl-silicate phases and then ultimately to uranyl-phosphate phases as long as adequate phosphate is present.

\subsection{1 $\quad{ }^{99} \mathrm{Tc}$ Solubility}

The solubilities of ${ }^{99}$ Tc for three LSW grout formulations were estimated by Um et al. (2016). The solubilities were determined under reducing conditions for a selected size fraction $(0.3-2 \mathrm{~mm})$ from crushed LSW grout samples in contact with ${ }^{99} \mathrm{Tc}(\mathrm{VII})$-spiked saturated $\mathrm{Ca}(\mathrm{OH})_{2}$ solution. Results through 51 days of testing are shown in Table 3.3 and suggest that the dissolved Tc concentration is $\sim 4.3$ $\times 10^{-9} \mathrm{M}$. The measured Tc concentrations are trending down with time and may not have reached equilibrium even after 51 days reaction. These values are conservative relative to expected values at equilibrium. The results are within the range of $10^{-9}$ to $10^{-8} \mathrm{M}$ reported by Estes et al. (2012) for Tc solubility with saltstone formulations with $17 \mathrm{wt} \%$, $45 \mathrm{wt} \%$, and $90 \mathrm{wt} \%$ BFS under reducing conditions measured through 319 days. Estes et al. (2012) concluded that under reducing conditions, the Tc concentrations are controlled by the solubility of a Tc(IV) oxide phase rather than a sulfide phase. Cantrell and Williams (2013) concluded that a $\mathrm{TcO}_{2} \bullet 1.6 \mathrm{H}_{2} \mathrm{O}$ phase was controlling the $\mathrm{Tc}(\mathrm{IV})$ solubility in saltstone samples, which agrees with Estes et al.(2012) in terms of the type of Tc(IV) phase---a Tc(IV) oxide phase.

\subsection{Physical and Hydraulic Properties of LSW Grouts Relevant to Contaminant Release}

As part of the most recent LSW grout formulation studies, Cozzi et al. (2016) determined densities, porosities, hydraulic conductivities, and water retention curves for LSW grouts cured for 28 days. Table 3.4 summarizes the densities, porosities, and saturated hydraulic conductivities. Moisture content measured by Um et al. (2016) is also shown in Table 3.4. Table 3.5 shows densities and porosities measured for Cast Stone formulations with LAW (Westsik et al. 2013). Each is discussed further in the following subsections.

\subsubsection{Hydraulic Conductivity}

Hydraulic conductivity of select LSW grout samples were determined by Cozzi et al. (2016). Cylindrical samples, 2-inch diameter $\times 4$-inch long were demolded, and the samples were trimmed to have parallel faces and a height of approximately 2 inches-a sample aspect ratio of 1 . After being trimmed, the samples were submerged in water and placed under vacuum to displace air and saturate the samples. Following vacuum saturation, the hydraulic conductivity was measured in a flexible wall permeameter using ASTM D 5084-10, Standard Test Methods for Measurement of Hydraulic Conductivity of Saturated Porous Materials Using a Flexible Wall Permeameter. No water permeated Mix 5 during the saturation period, therefore, the hydraulic conductivity reported was the detection limit of this test setup, $<1 \times 10^{-9} \mathrm{~cm} / \mathrm{s}$. Mix 10 had a relatively large $\mathrm{K}$ and, as a result, the test could not be run 
continuously. The neutral $\mathrm{pH}$ of the waste simulants does not accelerate the hydration of the blast furnace slag in the same way as caustic waste simulants.

\subsubsection{Porosity and Moisture Content}

Porosities were determined by Cozzi et al. (2016) using a weight loss method for the 14 test formulations for the LSW grout formulation studies. The volume of the pore solution is determined by assuming the mass loss is due entirely to water and dividing by the density of the pore solution and the volume fraction of water in the pore solution. The porosity measurement assumes $100 \%$ saturation. In general, the porosities tended to be lower for the formulations with a water-to-dry-blend mix ratio of 0.5 than for those with a water-to-dry-blend mix ratio of 0.6. The three mixes prepared with fly ash were more porous than those prepared with the hydrated lime, even with the addition of the Xypex to reduce the porosity of the fly ash mixes. Um et al. (2016) measured the moisture content by weight loss before and after drying at $105^{\circ} \mathrm{C}$ for 48 hours, cooling, measuring the mass, and drying for an additional 24 hours. The grout was not saturated prior to measuring the moisture content, because we need the true solid fraction of grout after the curing process. But, the $D_{\text {eff }}$ determined by EPA 1315 method was based on $100 \%$ saturation using the submerged grouts in leaching solution.

Water retention curves from Cozzi et al. (2016) are provided in Appendix E.

\subsubsection{Dry Bulk Density and Particle Density}

Both dry bulk density and particle density are shown in Table 3.4 for selected LSW grout formulations. The dry bulk density is the density of a dried bulk sample of the material-basically the dried grout mass divided by the volume of the grout including any porosity. The particle density is the density of the solid material only without any porosity. The densities in Table 3.5 are densities without drying and measured using helium pycnometry.

\subsubsection{Van Genuchten Transport Parameters}

Cozzi et al. (2016) measured water characteristic curves for single samples of mixes 3, 6, and 11 LSW grout formulations shown in Table 3.4. They used the measured vapor pressure method using a chilled mirror hygrometer according to ASTM D6836-02 Standard Test Methods for Determination of the Soil Water Characteristic Curve for Desorption Using Hanging Column, Pressure Extractor, Chilled Mirror Hygrometer, or Centrifuge, Method D. Measurements were made on $<2 \mathrm{~mm}$ crushed samples of the three LSW grout formulations. Drying (desorption) and wetting (adsorption) moisture characteristic curves were determined. The moisture characteristic curves were then used to estimate the parameters in the van Genuchten (1980) equation:

$$
S_{e}=\frac{1}{\left[1+(\alpha \psi)^{n}\right]^{m}}
$$

where

$\psi=$ matric potential

$S_{e}=$ effective saturation $=\frac{\theta-\theta_{r}}{\theta_{s}-\theta_{r}}, 0 \leq S_{e} \leq 1$

$\alpha=$ curve fitting parameter related to air entry pressure 


$$
\begin{aligned}
\mathrm{n}, \mathrm{m} & =\text { curve fitting parameters related to pore size distribution; the relationship, } \mathrm{m}=1-1 / \mathrm{n}, \text { is often } \\
\quad \text { assumed } & \\
\theta_{r} & =\text { residual (or irreducible) water content } \\
\theta_{s} & =\text { saturated water content. }
\end{aligned}
$$

Because the results of the testing for the formulations were similar, Cozzi et al. (2016) fit the parameters to combined datasets. The results are shown in Table 3.6. Confidence limits for the parameters in Table 3.6 that represent how well the data fits the model are shown in Table 3.7.

\subsection{Reductive Capacity of Cast Stone}

Blast furnace slag is added to Cast Stone and lime-based LSW grouts to increase their reducing capacity to maintain certain contaminants, such as Tc and Cr, in reduced, relatively insoluble forms. As the Cast Stone becomes oxidized, Tc and $\mathrm{Cr}$ can be oxidized to more mobile forms. As a result, reductive capacity is a parameter needed for PA modeling. Reduction capacity measurements have been made on the same 26 Cast Stone waste forms made with LAW simulants that were studied by Westsik et al. (2013). These results were reported in Um et al. (2013), and are shown in Table 3.8.

The reductive capacities for the LAW Cast Stone samples measured before leaching using the Ce(IV) (Angus and Glasser 1985) and Cr(VI) (Lee and Batchelor 2003) methods were also in good agreement. The results ranged from 0.541 to $1.490 \mathrm{meq} / \mathrm{g}$ using the Ce(IV) method and from 0.404 to $1.389 \mathrm{meq} / \mathrm{g}$ using the $\mathrm{Cr}(\mathrm{VI})$ method. In general, the reductive capacities measured by the $\mathrm{Ce}(\mathrm{IV})$ method were slightly higher than those measured by the $\mathrm{Cr}(\mathrm{VI})$ method. This has been attributed to the different $\mathrm{pH}$ conditions of the Ce(IV) and Cr(VI) methods (Um et al. 2013). The Ce(IV) method can measure nearly all the reductive capacity of the solid materials under acidic $\mathrm{pH}$ conditions because most of the solids dissolve; the $\mathrm{Cr}(\mathrm{VI})$ method is likely to measure only the reductive capacity of the solids' surfaces and any internal surfaces that the oxidant can reach in the available contact time at neutral $\mathrm{pH}$ or alkaline $\mathrm{pH}$, due to $\mathrm{pH}$ buffering during the reaction with powdered Cast Stone. 
Table 3.4. Density, Porosity, Moisture Content, and Hydraulic Conductivity of Selected LSW Grout Formulations

\begin{tabular}{|c|c|c|c|c|c|c|c|c|c|c|}
\hline $\begin{array}{l}\text { Test } \\
\text { ID }^{(a)}\end{array}$ & Simulant & $\begin{array}{c}\text { Water / } \\
\text { Dry } \\
\text { Blend } \\
\text { Ratio }\end{array}$ & $\begin{array}{c}\text { Dry Blend Mix } \\
\text { wt\% }\end{array}$ & $\begin{array}{c}\text { Dry Blend } \\
\text { Components }\end{array}$ & $\begin{array}{c}\text { Dry Bulk } \\
\text { Density } \\
\left(\mathrm{g} / \mathrm{cm}^{3}\right)\end{array}$ & $\begin{array}{c}\text { Cured } \\
\text { Geometric } \\
\text { Density } \\
\left(\mathrm{g} / \mathrm{cm}^{3}\right)\end{array}$ & $\begin{array}{l}\text { Porosity } \\
\text { (\%) }\end{array}$ & $\begin{array}{l}\text { Particle } \\
\text { Density } \\
\left(\mathrm{g} / \mathrm{cm}^{3}\right)\end{array}$ & $\begin{array}{l}\text { Gravimetric } \\
\text { Moisture } \\
\text { Content } \\
\text { (\%) }\end{array}$ & $\begin{array}{c}\text { Hydraulic } \\
\text { Conductivity } \\
(\mathrm{cm} / \mathrm{s})\end{array}$ \\
\hline 1 & 242-A & 0.5 & $20 \%, 35 \%, 45 \%$ & lime, OPC, BFS & - & 1.78 & 49.82 & - & 27.1 & - \\
\hline 2 & ERDF & 0.5 & $20 \%, 35 \%, 45 \%$ & lime, OPC, BFS & - & 1.82 & 47.77 & - & 25.0 & - \\
\hline 3 & WTP & 0.5 & $20 \%, 35 \%, 45 \%$ & lime, OPC, BFS & 1.31 & 1.76 & 54.82 & 2.77 & 25.1 & $2.6 \times 10^{-9}$ \\
\hline 4 & $242-A$ & 0.6 & $20 \%, 35 \%, 45 \%$ & lime, OPC, BFS & - & 1.70 & 54.96 & - & 30.6 & - \\
\hline 5 & ERDF & 0.6 & $20 \%, 35 \%, 45 \%$ & lime, OPC, BFS & - & 1.71 & 51.78 & - & 29.4 & $<1 \times 10^{-9}$ \\
\hline 6 & WTP & 0.6 & $20 \%, 35 \%, 45 \%$ & lime, OPC, BFS & 1.20 & 1.73 & 58.61 & 2.75 & 29.7 & $3.9 \times 10^{-9}$ \\
\hline 7 & ERDF & 0.5 & $20 \%, 35 \%, 45 \%$ & lime, OPC, BFS & - & 1.78 & 48.56 & - & 25.5 & - \\
\hline 8 & WTP & 0.6 & $20 \%, 35 \%, 45 \%$ & lime, OPC, BFS & - & 1.73 & 58.80 & - & 29.8 & $<1 \times 10^{-9}$ \\
\hline 9 & $242-A$ & 0.5 & $20 \%, 10 \%, 70 \%$ & lime, OPC, BFS & - & 1.74 & 53.13 & - & 27.9 & - \\
\hline 10 & WTP & 0.5 & $20 \%, 10 \%, 70 \%$ & lime, OPC, BFS & - & 1.75 & 46.72 & - & 27.5 & $7.1 \times 10^{-6}$ \\
\hline 11 & WTP & 0.6 & $20 \%, 35 \%, 45 \%$ & OPC, FA, BFS & 1.19 & 1.74 & $60.07^{(\mathrm{c})}$ & 2.82 & 30.4 & $1.54 \times 10^{-9}$ \\
\hline 12 & $242-A$ & 0.6 & $20 \%, 35 \%, 45 \%$ & OPC, FA, BFS & - & 1.74 & $57.29^{(\mathrm{c})}$ & - & 29.6 & - \\
\hline 13 & WTP & 0.6 & $8 \%, 45 \%, 47 \%$ & OPC, FA, BFS & - & 1.72 & 60.24 & - & 26.6 & - \\
\hline 14 & $\begin{array}{c}242- \\
\mathrm{A}+\mathrm{ERDF}^{(\mathrm{d})}\end{array}$ & 0.5 & $20 \%, 35 \%, 45 \%$ & lime, OPC, BFS & - & 1.77 & 48.94 & - & 25.7 & - \\
\hline Average & - & 0.5 & - & lime, OPC, BFS & - & - & 50.0 & - & 26.3 & - \\
\hline Average & - & 0.6 & - & lime, OPC, BFS & - & - & 56.0 & - & 29.4 & - \\
\hline \multicolumn{3}{|c|}{ All wastes in Saltstone PA ${ }^{(\mathrm{e})}$} & - & - & 1.01 & - & 58 & 2.40 & - & $6.4 \times 10^{-9}$ \\
\hline
\end{tabular}

(a) Cozzi et al. (2016). These are the same formulations as Um et al. (2016).

(b) Um et al. (2016). Moisture contents were measured gravimetrically for the 28-days cured grout monoliths without additional saturation

(c) Dry-blend mix included $5 \mathrm{wt} \%$ Xypex as a filler to reduce porosity.

(d) Simulant in Test 14 was prepared using a mixture of 242-A and ERDF simulants at a 1:1 ratio based on mass.

(e) SRR CWDA (2014) 
Table 3.5. Density and Porosity of Selected Cast Stone Formulations

\begin{tabular}{|c|c|c|c|c|c|c|c|c|c|}
\hline \multirow[b]{2}{*}{ Test ID } & \multirow[b]{2}{*}{ Simulant } & \multirow[b]{2}{*}{$\begin{array}{l}\text { Sodium } \\
\text { Molarity }\end{array}$} & \multirow{2}{*}{$\begin{array}{c}\text { Water / } \\
\text { Dry Blend } \\
\text { Ratio }\end{array}$} & \multirow[b]{2}{*}{$\begin{array}{l}\text { Fly Ash } \\
\text { Class F }\end{array}$} & \multirow[b]{2}{*}{$\begin{array}{l}\text { BFS } \\
\text { Source }\end{array}$} & \multicolumn{2}{|c|}{ Density } & \multicolumn{2}{|c|}{ Porosity } \\
\hline & & & & & & $\left(\mathrm{g} / \mathrm{cm}^{3}\right)$ & $\mathrm{SD}^{(\mathrm{a})}$ & (\%) & $\mathrm{SD}^{(\mathrm{a})}$ \\
\hline 1 & High $\mathrm{SO}_{4}$ & 5.0 & 0.40 & SE Low $\mathrm{Ca}$ & NW & 1.898 & 0.0006 & 48.2 & 0.42 \\
\hline 2 & Average & 5.0 & 0.60 & SE Low Ca & $\mathrm{SE}$ & 1.772 & 0.0117 & 55.1 & 0.25 \\
\hline 3 & Average & 7.8 & 0.60 & NW High Ca & SE & - & - & - & - \\
\hline 4 & High Al & 5.0 & 0.40 & NW High Ca & SE & - & - & - & - \\
\hline 5 & Average & 7.8 & 0.40 & NW High Ca & NW & - & - & - & - \\
\hline 6 & Average & 7.8 & 0.40 & SE Low Ca & NW & 1.938 & 0.0015 & 51.0 & 0.31 \\
\hline 7 & High $\mathrm{SO}_{4}$ & 7.8 & 0.40 & SE Low Ca & SE & 1.938 & 0.0015 & 47.4 & 0.12 \\
\hline 8 & SST Blend & 5.0 & 0.40 & SE Low Ca & NW & 1.888 & 0.0044 & 50.7 & 0.38 \\
\hline 9 & $\mathrm{Hi} \mathrm{Al}$ & 7.8 & 0.60 & NW High Ca & SE & - & - & - & - \\
\hline 10 & High $\mathrm{SO}_{4}$ & 5.0 & 0.60 & NW High Ca & NW & - & - & - & - \\
\hline 11 & High Al & 7.8 & 0.60 & SE Low Ca & NW & 1.784 & 0.0040 & 60.8 & 0.40 \\
\hline 12 & SST Blend & 5.0 & 0.60 & NW High Ca & SE & - & - & - & \\
\hline 13 & Average & 5.0 & 0.60 & SE Low Ca & SE & 1.763 & 0.0055 & 55.0 & 0.20 \\
\hline 14 & High $\mathrm{SO}_{4}$ & 7.8 & 0.40 & SE Low Ca & SE & 1.936 & 0.0051 & 47.6 & 0.35 \\
\hline 15 & High $\mathrm{SO}_{4}$ & 7.8 & 0.40 & NW High Ca & NW & - & - & - & - \\
\hline 16 & SST Blend & 7.8 & 0.40 & NW High Ca & NW & - & - & - & - \\
\hline 17 & High Al & 5.0 & 0.60 & SE Low Ca & SE & 1.773 & 0.0029 & 57.1 & 0.06 \\
\hline 18 & SST Blend & 7.8 & 0.40 & SE Low Ca & SE & 1.923 & 0.0064 & 48.6 & 0.12 \\
\hline 19 & High Al & 7.8 & 0.40 & SE Low Ca & NW & 1.928 & 0.0012 & 53.0 & 3.18 \\
\hline 20 & Average & 5.0 & 0.40 & NW High Ca & SE & - & - & - & \\
\hline 21 & High $\mathrm{SO}_{4}$ & 7.8 & 0.60 & SE Low Ca & NW & 1.794 & 0.0045 & 62.2 & 0.31 \\
\hline 22 & Average & 7.8 & 0.60 & NW High Ca & SE & - & - & - & - \\
\hline 23 & SST Blend & 7.8 & 0.60 & SE Low Ca & NW & 1.807 & 0.0049 & 62.4 & 2.15 \\
\hline 24 & High Al & 5.0 & 0.60 & NW High Ca & NW & - & - & - & - \\
\hline 25 & High $\mathrm{SO}_{4}$ & 7.8 & 0.40 & NW High Ca & NW & - & - & - & - \\
\hline 26 & High $\mathrm{SO}_{4}$ & 7.8 & 0.60 & SE Low Ca & NW & 1.804 & 0.0057 & 61.5 & 0.29 \\
\hline Average & - & - & 0.4 & - & - & 1.92 & - & 49.5 & - \\
\hline Average & - & - & 0.6 & - & - & 1.79 & - & 59.2 & - \\
\hline
\end{tabular}


Table 3.6. Van Genuchten Transport Parameters Data

\begin{tabular}{lcccccc}
\hline \multicolumn{1}{c}{ Material } & $\begin{array}{c}\theta_{\mathrm{s}}^{(\mathrm{a})} \\
\left(\mathrm{cm}^{3} / \mathrm{cm}^{3}\right)\end{array}$ & $\begin{array}{c}\theta_{\mathrm{r}} \\
\left(\mathrm{cm}^{3} / \mathrm{cm}^{3}\right)\end{array}$ & $\begin{array}{c}\alpha^{(\mathrm{b})} \\
(1 / \mathrm{cm})\end{array}$ & $\mathrm{n}$ & $\mathrm{m}$ & $\mathrm{r}^{2}$ \\
\hline Secondary Waste - Drying & 0.5569 & 0.06375 & $3.26 \mathrm{E}-06$ & 1.94086 & 0.48476 & 0.978 \\
Secondary Waste - Wetting & 0.5569 & 0.06097 & $7.45 \mathrm{E}-06$ & 1.79683 & 0.44346 & 0.965 \\
Secondary Waste - Combined & 0.5569 & 0.06000 & $6.03 \mathrm{E}-06$ & 1.64883 & 0.39351 & 0.848 \\
Saltstone PA & 0.5800 & 0.00000 & $1.008 \mathrm{E}-05$ & 1.67131 & 0.40167 & 0.986 \\
\hline
\end{tabular}

(a) set equal to the average measured porosity in Table 3.5 .

(b) $\alpha$ calculated using van Genuchten empirical relationship for moisture retention data.

Table 3.7. 95\% Confidence Limits for Van Genuchten Transport Parameters

\begin{tabular}{|c|c|c|c|c|c|c|c|c|}
\hline \multirow[b]{2}{*}{ Material } & \multicolumn{2}{|c|}{$\begin{array}{c}\theta_{\mathrm{s}}^{(\mathrm{a})} \\
\left(\mathrm{cm}^{3} / \mathrm{cm}^{3}\right)\end{array}$} & \multicolumn{2}{|c|}{$\begin{array}{c}\theta_{\mathrm{r}} \\
\left(\mathrm{cm}^{3} / \mathrm{cm}^{3}\right)\end{array}$} & \multicolumn{2}{|c|}{$\begin{array}{c}\alpha^{(\mathrm{b})} \\
(1 / \mathrm{cm})\end{array}$} & \multicolumn{2}{|c|}{$\mathrm{n}$} \\
\hline & Lower & Upper & Lower & Upper & Lower & Upper & Lower & Upper \\
\hline Secondary Waste - Wetting & - & - & 0.0000 & 0.2480 & - & - & 1.2227 & 2.3709 \\
\hline Secondary Waste - Drying & - & - & 0.0000 & 0.1460 & - & - & 1.5880 & 2.2937 \\
\hline Secondary Waste - Combined & - & - & - & - & - & - & 1.4946 & 1.8030 \\
\hline
\end{tabular}

(a) set equal to the average measured porosity in Table 3.5 .

(b) Fitting software output precision for $\alpha$ insufficient to provide confidence limits

The reductive capacity measured by the Ce(IV) method was the highest for the Cast Stone made with "High Al” simulant, which was on average $1.040 \mathrm{meq} / \mathrm{g}$ for $5 \mathrm{M}$ Na Cast Stone and $1.390 \mathrm{meq} / \mathrm{g}$ for 7.8 M Na Cast Stone. Higher reductive capacity was also found in the 7.8 M Na simulant than in $5 \mathrm{M} \mathrm{Na}$ simulants because of the higher nitrite concentration added in the 7.8 M Na simulant. Cast Stone samples made with the "Average" simulant showed the second-highest reductive capacity (0.609 meq/g for $5 \mathrm{M} \mathrm{Na}$ and $0.763 \mathrm{meq} / \mathrm{g}$ for $7.8 \mathrm{M} \mathrm{Na}$ ), followed by the Cast Stone made with the "High $\mathrm{SO}_{4}$ " simulant ( $0.578 \mathrm{meq} / \mathrm{g}$ for $5 \mathrm{M} \mathrm{Na}$ and $0.667 \mathrm{meq} / \mathrm{g}$ for $7.8 \mathrm{M} \mathrm{Na}$ ), and the "SST Blend" simulant $(0.575 \mathrm{meq} / \mathrm{g}$ for $5 \mathrm{M} \mathrm{Na}$ and $0.659 \mathrm{meq} / \mathrm{g}$ for $7.8 \mathrm{M} \mathrm{Na}$ ). The reductive capacities measured by the $\mathrm{Cr}(\mathrm{VI})$ method exhibited the same pattern, with the highest reductive capacity for the "High Al" Cast Stone, followed by the "Average" Cast Stone, the "High $\mathrm{SO}_{4}$ " Cast Stone, and the "SST Blend" Cast Stone. The reductive capacities of Cast Stone samples measured by both the $\mathrm{Ce}(\mathrm{IV})$ and $\mathrm{Cr}(\mathrm{VI})$ methods thus show a good correlation $\left(\mathrm{R}^{2}=0.96\right)$.

Additional reductive capacity measurements have been made on Cast Stone waste forms made with secondary waste simulants. These results were reported in Um et al. (2011). Measurements were made using simulants both with and without Tc added. Results with and without Tc added were very similar as one might expect given the low masses of Tc(VII) spiked into the waste forms. Only results for waste forms without Tc added are discussed here. The reductive capacities measured for these samples were significantly less than those measured for the Cast Stone waste forms made with LAW simulants, ranging from $0.399 \mathrm{meq} / \mathrm{g}$ to $0.596 \mathrm{meq} / \mathrm{g}$ as measured by the Ce(IV) method, and from $0.179 \mathrm{meq} / \mathrm{g}$ to 0.212 meq/g by the $\mathrm{Cr}(\mathrm{VI})$ method. The measured reductive capacity shows a trend that increases with an increasing $\mathrm{Na}$ concentration (which correlates with nitrite concentrations) in the simulant because of increasing nitrite concentration (Table 3.9). 
Table 3.8. Reductive Capacity (meq/g) Measurement Result for Cast Stone Samples Made with LAW Simulants (Um et al. 2013)

\begin{tabular}{|c|c|c|c|c|c|c|c|}
\hline $\begin{array}{c}\text { Test } \\
\text { ID }\end{array}$ & $\begin{array}{c}\text { Waste } \\
\text { Composition }\end{array}$ & $\begin{array}{l}\text { Na Conc. } \\
\text { (mol/L) }\end{array}$ & $\begin{array}{l}\text { Fly Ash } \\
\text { Source }\end{array}$ & $\begin{array}{c}\text { Slag } \\
\text { Source }\end{array}$ & $\begin{array}{c}\text { Water/Dry } \\
\text { Blend Ratio }\end{array}$ & $\begin{array}{l}\text { Ce(IV) Reductive } \\
\text { Capacity (meq/g) }\end{array}$ & $\begin{array}{l}\mathrm{Cr}(\mathrm{VI}) \text { Reductive } \\
\text { Capacity (meq/g) }\end{array}$ \\
\hline 1 & High $\mathrm{SO}_{4}$ & 5.0 & $\mathrm{SE}$ & NW & 0.4 & 0.591 & 0.554 \\
\hline 2 & Average & 5.0 & SE & SE & 0.6 & 0.672 & 0.646 \\
\hline 3 & Average & 7.8 & NW & SE & 0.6 & 0.784 & 0.847 \\
\hline 4 & High Al & 5.0 & NW & SE & 0.4 & 1.470 & 1.389 \\
\hline 5 & Average & 7.8 & NW & NW & 0.4 & 0.699 & 0.726 \\
\hline 6 & Average & 7.8 & SE & NW & 0.4 & 0.750 & 0.686 \\
\hline 7 & High $\mathrm{SO}_{4}$ & 7.8 & $\mathrm{SE}$ & SE & 0.4 & 0.693 & 0.685 \\
\hline 8 & SST Blend & 5.0 & SE & NW & 0.4 & 0.603 & 0.404 \\
\hline 9 & High Al & 7.8 & NW & SE & 0.6 & 1.449 & 1.346 \\
\hline 10 & High $\mathrm{SO}_{4}$ & 5.0 & NW & NW & 0.6 & 0.565 & 0.545 \\
\hline 11 & High Al & 7.8 & SE & NW & 0.6 & 1.490 & 1.330 \\
\hline 12 & SST Blend & 5.0 & NW & SE & 0.6 & 0.546 & 0.583 \\
\hline 13 & Average & 5.0 & SE & SE & 0.6 & 0.612 & 0.606 \\
\hline 14 & High $\mathrm{SO}_{4}$ & 7.8 & SE & SE & 0.4 & 0.663 & 0.664 \\
\hline 15 & High $\mathrm{SO}_{4}$ & 7.8 & NW & NW & 0.4 & 0.601 & 0.705 \\
\hline 16 & SST Blend & 7.8 & NW & NW & 0.4 & 0.578 & 0.667 \\
\hline 17 & High Al & 5.0 & SE & SE & 0.6 & 0.841 & 0.766 \\
\hline 18 & SST Blend & 7.8 & SE & SE & 0.4 & 0.678 & 0.482 \\
\hline 19 & High Al & 7.8 & $\mathrm{SE}$ & NW & 0.4 & 1.231 & 1.007 \\
\hline 20 & Average & 5.0 & NW & SE & 0.4 & 0.541 & 0.443 \\
\hline 21 & High $\mathrm{SO}_{4}$ & 7.8 & SE & NW & 0.6 & 0.702 & 0.686 \\
\hline 22 & Average & 7.8 & NW & SE & 0.6 & 0.819 & 0.837 \\
\hline 23 & SST Blend & 7.8 & SE & NW & 0.6 & 0.720 & 0.606 \\
\hline 24 & High Al & 5.0 & NW & NW & 0.6 & 0.810 & 0.929 \\
\hline 25 & High $\mathrm{SO}_{4}$ & 7.8 & NW & NW & 0.4 & 0.614 & 0.645 \\
\hline 26 & High $\mathrm{SO}_{4}$ & 7.8 & SE & NW & 0.6 & 0.732 & 0.808 \\
\hline
\end{tabular}

Specific recommendations for Cast Stone reductive capacity are not made here because the values vary significantly depending upon the composition of the waste stream and water-to-dry-blend mix ratio used to make up the waste forms. However, an overall range for Cast Stone reductive capacity is about 0.4-1.5 meq/g. Once the compositions of the secondary waste streams are better defined, a more reasonable range of values could be selected based on the data provided in this section. Alternately direct measurement of the reductive capacity of any future specific grout mix-waste simulant cured specimen is inexpensive. 
Table 3.9. Reductive Capacity Results for Secondary Waste Forms without Tc Added (Um et al. 2011)

\begin{tabular}{lccc}
\hline \multicolumn{1}{c}{ Sample ID } & Simulant & $\begin{array}{c}\text { Ce(IV) Reductive } \\
\text { Capacity (meq/g) }\end{array}$ & $\begin{array}{c}\text { Cr(VI) Reductive } \\
\text { Capacity (meq/g) }\end{array}$ \\
\hline Cast Stone S1-2M & S1 (2-M Na) & 0.399 & 0.185 \\
Cast Stone S1-4M & S1 (4-M Na) & 0.442 & 0.182 \\
Cast Stone S1-6M & S1 (6-M Na) & 0.485 & 0.193 \\
Cast Stone S1-8M & S1 (8-M Na) & 0.540 & 0.189 \\
Cast Stone S1-10M & S1 (10-M Na) & 0.596 & 0.179 \\
Cast Stone S2-2M & S2 (2-M Na) & 0.402 & 0.184 \\
Cast Stone S3-2M & S3 (2-M Na) & 0.450 & 0.200 \\
Cast Stone S4-2M & S4 (2-M Na) & 0.461 & 0.212 \\
\hline
\end{tabular}

\subsection{Release of ${ }^{129}$ I from Grout Encapsulated Activated Carbon}

Current WTP flow-sheet projections suggest that significant quantities of ${ }^{129}$ I will be captured in the granular activated carbon (GAC) beds that possibly will be encapsulated in grout waste packages that are then disposed of in the IDF as solid secondary wastes. If this is the ultimate disposal pathway for this ${ }^{129} \mathrm{I}$ waste form, then the release of ${ }^{129}$ I species from the grouted solid secondary waste forms will need to be considered in future IDF PAs. Two conceptual release models are possible for this ${ }^{129}$ I-laden waste form, desorption $K_{d}$ values or effective diffusion coefficients, $\mathrm{D}_{\mathrm{e}}$, values.

A literature search did not find any articles that addressed release of ${ }^{129}$ I from GAC or any form of activated carbon that had been encapsulated in grout. There is some literature on the adsorption of iodine species — iodide, iodate, dissolved free $\mathrm{I}_{2}$, and dissolved organic bound iodine — onto activated carbon from contaminated groundwater and other natural waters (river, lake and seawater) and desorption of ${ }^{129} \mathrm{I}$ loaded onto activated carbon. A separate data package is being prepared for solid secondary wastes encapsulated in cementitious waste forms.

In summary, the articles found in the literature search suggest that activated carbon can adsorb all common iodine aqueous species (iodide, iodate, and dissolved $\mathrm{I}_{2}$ ) from various aqueous solutions with $K_{d}$ values generally ranging from 20 to at least $800 \mathrm{~mL} / \mathrm{g}$. The adsorption kinetics are relatively fast (minutes to a few days) to reach steady state residual solution concentrations. Desorption tests conducted by Kaplan et al. (1999) and Kaplan and Serkiz (2000) on ${ }^{129}$ I-laden ACs showed relatively conservative ${ }^{129}$ I desorption $K_{d}$ values between 320 and $880 \mathrm{~mL} / \mathrm{g}$ when the ${ }^{129}$ I-laden ACs were leached with a simulated cement pore water with caustic $\mathrm{pH}$ similar to expected grout leachates from cementitious waste forms and grout encapsulated solid secondary wastes. 


\subsection{Summary}

A review of the most relevant data currently available for modeling contaminant release from secondary waste cementitious waste forms was completed to develop a set of recommended values for use in the next IDF PA. This data package relies primarily upon more recent data collected on current Cast Stone formulations fabricated with LAW waste simulants and secondary waste simulants expected to be produced at Hanford. These data were supplemented, when necessary, with data developed for saltstone. Because data for cementitious waste forms fabricated with secondary waste simulants is limited, data reported on Cast Stone waste forms fabricated with LAW simulants is included in the review. This additional data provides a perspective on how variable contaminant release-rate parameters are as a function of waste composition and to a limited extent as a function of free-water-to-dry-blend mix ratio.

The effective diffusivity and other data provided in this data package can be used to model contaminant release using simplified release models such as those used in the previous IDF PAs. In addition, the IDF modeling team is considering alternative analysis methods similar to what was used for the saltstone PA. Some of the data provided here as well as additional data currently being generated can be used to support a more rigorous alternative for modeling contaminant release from cementitious waste forms disposed in the IDF.

Currently, studies are ongoing that will generate additional data that will be used to supplement and/or update the data tabulated in this data package. These ongoing studies will facilitate the periodic revision of this data package as more data become available and the waste form recipe and secondary waste streams become better defined. 



\subsection{References}

Albenesius EL. 2001. Computer Modeling of Saltstone Landfills by Intera Environmental Consultants. DPST-83-529, Savannah River Site, Aiken, South Carolina.

Angus MJ and FP Glasser. 1985. “The Chemical Environment in Cement Matrices.” Mat. Res. Soc. Symp. Proc. 50:547-556.

ANSI/ANS-American National Standards Institute/American Nuclear Society. 2003. Measurement of the Leachability of Solidified Low-Level Radioactive Wastes by a Short Term Test Procedure. ANSI/ANS-16.1, La Grange Park, Illinois.

Asmussen RM, NP Qafoku, AR Lawter, and JJ Neeway. 2015. Interim Report: Getters and Cast Stone with Getters: Tc and I Sorption and Release Rates. PNNL-24700, Pacific Northwest National Laboratory, Richland, WA.

ASTM B553-79. Test Method for Thermal Cycling of Electroplated Plastics (Withdrawn 1991). ASTM International, West Conshohocken, Pennsylvania.

ASTM C39/C39M-10. Standard Test Method for Compressive Strength of Cylindrical Concrete Specimens. ASTM International, West Conshohocken, Pennsylvania.

ASTM C618. Standard Specification for Coal Fly Ash and Raw or Calcined Natural Pozzolan for Use in Concrete, ASTM International, West Conshohocken, Pennsylvania.

ASTM C1308-08. Standard Test Method for Accelerated Leach Test for Diffusive Releases from Solidified Waste and a Computer Program to Model Diffusive, Fractional Leaching from Cylindrical Waste Forms. ASTM International, West Conshohocken, Pennsylvania.

ASTM D 5084-10. Standard Test Methods for Measurement of Hydraulic Conductivity of Saturated Porous Materials Using a Flexible Wall Permeameter, ASTM International, West Conshohocken, Pennsylvania.

ASTM D6836-02. Standard Test Methods for Determination of the Soil Water Characteristic Curve for Desorption Using Hanging Column, Pressure Extractor, Chilled Mirror Hygrometer, or Centrifuge. ASTM International, West Conshohocken, Pennsylvania.

Atkins M and FP Glasser. 1992. “Application of Portland-Cement-Based Materials to Radioactive Waste Immobilization.” Waste Management 12:105-131.

Atkinson A, K Nelson, and TM Valentine. 1986. "Leach Test Characterization of Cement-Based Nuclear Waste Forms.” Nucl. \& Chem. Waste Manage. 6:241-253.

Atkinson A and AK Nickerson. 1988. "Diffusion and Sorption of Cesium, Strontium, and Iodine in Water-Saturated Cement.” Nuc. Tech. 81(1):100-113. 
Atkinson A, NM Everitt, and RM Guppy. 1989. "Time Dependence of pH in a Cementitious Repository.” Mat. Res. Soc. Symp. Proc. 127:439-446.

Bacon DH, BP McGrail, VL Freedman, G Ventura, P Risoluti, and KM Krupka. 2002. "Performance Assessment of Low-Level Waste Disposal Facilities Using Coupled Unsaturated Flow and Reactive Transport Simulators.” Mat. Res. Soc. Symp. Proc. 713:267-274.

Berner UR. 1992. "Evolution of Pore Water Chemistry During Degradation of Cement in a Radioactive Waste Repository.” Waste Management 12:201-219.

Cantrell KJ. 2015. Secondary Waste Cementitious Waste Form Data Package for the Integrated Disposal Facility Performance Assessment. PNNL-24081, Pacific Northwest National Laboratory, Richland, WA.

Cantrell KJ and BD Williams. 2013. "Solubility Control of Technetium Release from Saltstone by $\mathrm{TcO}_{2} \bullet \mathrm{xH}_{2} \mathrm{O}$.” Journal of Nuclear Materials 437(1-3):424-431.

CBP. 2009a. Overview of the U.S. Department of Energy and Nuclear Regulatory Commission Performance Assessment Approaches. CBP-TR-2009-001, Cementitious Barriers Partnership, Consortium for Risk Evaluation with Stakeholder Participation, Vanderbilt University, Nashville, TN.

CBP. 2009b, Review of Mechanistic Understanding and Modeling and Uncertainty Analysis Methods for Predicting Cementitious Barrier Performance. CBP-TR-2009-002, Cementitious Barriers Partnership, Consortium for Risk Evaluation with Stakeholder Participation, Vanderbilt University, Nashville, TN.

Cook JR and JR Fowler. 1992. Radiological Performance Assessment for the Z-Area Disposal Facility (U). WSRC-RP-92-1360, Rev. 0, Westinghouse Savannah River Company, Aiken, South Carolina.

Cook J, D Kocher, L McDowell-Boyer, and E Wilhite. 2002. Special Analysis: Reevaluation of the Inadvertent Intruder, Groundwater, Air, and Radon Analyses for the Saltstone Disposal Facility. WSRC-TR-2002-00456, Rev. 0, Westinghouse Savannah River Company Aiken, South Carolina.

Cook JR, EL Wilhite, RA Hiergesell, and GA Flach. 2005. Special Analysis: Revision of the Saltstone Vault 4 Disposal Limits (U). WSRC-TR-2005-00074, Westinghouse Savannah River Company Aiken, South Carolina.

Cozzi, AD, KL Dixon, KA Hill, WD King, and RL Nichols. 2016. Liquid Secondary Waste: Waste Formulation and Qualification. SRNL-STI-2015-00685, Savannah River National Laboratory, Aiken, SC.

Crank, J. 1975. The Mathematics of Diffusion. Second edition, Oxford University Press, New York.

Criscenti LJ, RJ Serne, KM Krupka, and MI Wood. 1996. Predictive Calculations to Assess the Long-Term Effect of Cementitious Materials on the pH and Solubility of Uranium(VI) in a Shallow-Land Disposal Environment. PNNL-11182, Pacific Northwest National Laboratory, Richland, Washington.

DOE-U.S. Department of Energy. 1999. Order 435.1. Radioactive Waste Management. U.S. Department of Energy, Washington DC. 
DOE-U.S. Department of Energy. 2005. Technical Guidance Document for Tank Closure Environmental Impact Statement Vadose Zone and Groundwater Revised Analyses. U.S. Department of Energy, Washington DC.

DOE-U.S. Department of Energy. 2012. Final Tank Closure and Waste Management Environmental Impact Statement for the Hanford Site, Richland, Washington. DOE/EIS-0391, US Department of Energy, Washington, DC.

EPA-U.S. Environmental Protection Agency. 1999. Toxicity Characteristic Leaching Procedure. Test Methods for Evaluating Solid Wastes - Physical and Chemical Methods. SW-846, Method 1311. U.S. Environmental Protection Agency, Washington, D.C.

EPA-U.S. Environmental Protection Agency. 2004. Paint Filters Liquids Test - Physical and Chemical Methods. SW-846, Method 9095B, Rev. 2. U.S. Environmental Protection Agency, Washington, D.C.

EPA-U.S. Environmental Protection Agency. 2013a. Method 1315, Revision 0, Mass Transfer Rates of Constituents in Monolith or Compacted Granular Materials Using a Semi-Dynamic Tank Leaching Procedure. SW-846, U.S. Environmental Protection Agency, Washington, D.C.

EPA-U.S. Environmental Protection Agency. 2013b. Method 1313, Revision 0, "Liquid-Solid Partitioning as a Function of Eluate $\mathrm{pH}$ using a Parallel Batch Procedure.” In: Test Methods for Evaluating Solid Waste: Physical/Chemical Methods. SW-846, U.S. Environmental Protection Agency, Washington, D.C.

Estes SL, DI Kaplan, and BA Powell. 2012. Technetium Sorption by Cementitious Materials Under Reducing Conditions. SRNL-STI-2012-00596. Savannah River National Laboratory, Aiken, South Carolina.

Ewart FS, SW Pugh, and D Woodwark. 1988. Chemical and Microbiological Effects in the Near Field: Current Status. Report NSS/G103, U.K. Nirex Ltd., Harwell, United Kingdom.

Flach, GP, DI Kaplan, RL Nichols, RR Seitz and RJ Serne. 2016. Solid Secondary Waste Data Package Supporting Hanford Integrated Disposal Facility Performance Assessment, SRNL-STI-2016-00175, Revision 0, Savannah River National Laboratory, Aiken SC.

Fox KM, KA Roberts, and TB Edwards. 2014. Cast Stone Formulations at Higher Sodium Concentrations. SRNL-STI-2013-00499, Rev. 2, Savannah River Site, Aiken, South Carolina.

Freedman VL, JV Ryan, and DH Bacon. 2015. Glass Release Data Package for the Integrated Disposal Facility Performance Assessment. PNNL-24148, Pacific Northwest National Laboratory, Richland, WA.

Grathwohl P. 1998. Diffusion in Natural Porous Media: Contaminant Transport, Sorption/desorption and Dissolution Kinetics. Kluwer Academic Publishers, Berlin, Germany. ISBN 0-7923-8102-5

Halgren DL. 2012. 200 Area Effluent Treatment Facility Basin 432012 Campaign Process Control Plan. CHPRC-01871, Revision 1, CH2MHill Plateau Remediation Company, Richland, Washington. 
Halgren DL. 2013. 200 Area Effluent Treatment Facility Basin 42 Campaign 2013 Process Control Plan. CHPRC-02039, Revision 0, CH2MHill Plateau Remediation Company, Richland, Washington.

Hespe ED. 1971. "Leach Testing of Immobilized Radioactive Waste Solids: A Proposal for a Standard Method.” Atomic Energy Review 9:195-207, International Atomic Energy Agency, Vienna, Austria.

Hewlett PC. 1998. Lea's Chemistry of Cement and Concrete. Fourth Edition, Reed Educational and Professional Publishing Ltd.

IAEA-International Atomic Energy Agency. 1993. Improved Cement Solidification of Low- and Intermediate-Level Radioactive Wastes. Technical Reports Series No. 350, International Atomic Energy Agency, Vienna, Austria.

Kaplan DI. 2010. Geochemical Data Package for Performance Assessment Calculations Related to the Savannah River Site. SRNL-STI-2009-00473, Rev. 0, Savannah River Site, Aiken, South Carolina.

Kaplan DI and SM Serkiz. 2000. ${ }^{129}$ Iodine Desorption from Resin, Activated Carbon, and Filtercake Waste Generated from the F- and H-Area Water Treatment Units. WSRC-TR-2000-00308, Westinghouse Savannah River Company, Aiken, SC.

Kaplan DI, SM Serkiz, and NC Bell. 1999. I-129 Desorption from SRS Water Treatment Media from the Effluent Treatment Facility and the F-Area Groundwater Treatment Facility. WSRC-TR-99-00270, Westinghouse Savannah River Company, Aiken, SC.

Krupka KM and RJ Serne. 1996. Performance Assessment of Low-Level Radioactive Waste Disposal Facilities: Effects on Radionuclide Concentrations by Cement/Ground-Water Interactions. NUREG/CR-6377, U.S. Nuclear Regulatory Commission, Washington, D.C.

Krupka KM, RJ Serne, and DI Kaplan. 2004. Geochemical Data Package for the 2005 Hanford Integrated Disposal Facility Performance Assessment. PNNL-13037, Rev. 2, Pacific Northwest National Laboratory, Richland, Washington.

Langton CA. 1986. Slag-Substituted Concrete for Saltstone Vault Construction. DPST-86-830, Savannah River Laboratory, Aiken, South Carolina.

Langton CA. 1987. “Slag-Based Saltstone Formulations.” MRS Proceedings 112:61-70.

Langton CA. 1989. Slag-Based Materials for Toxic Metal and Radioactive Waste Stabilization. DP-MS-87-95, Rev. 2, E. I. du Pont de Nemours \& Co., Savannah River Laboratory, Aiken, South Carolina.

Langton CA and DB Stefanko. 2012. Oxidation Study: Chromium and Rhenium Leaching Front Results. SRNL-L3100-2012-00033, Revision 0, Savannah River National Laboratory, Savannah River Site, Aiken, South Carolina.

Langton CA, DB Stefanko, and HH Burns. 2013. "Saltstone Oxidation Study: Leaching Method 13092.” WM2013 Conference Proceedings, February 24-28, 2013, Phoenix, Arizona. 
Langton CA. 2014. Technetium Oxidation in Slag-Based Sodium Salt Waste Forms Exposed to Water and Moist Hanford Soil. SRNL-STI-2014-00399, Revision 0, Savannah River National Laboratory, Savannah River Site, Aiken, South Carolina.

Last GV, MMV Snyder, W Um, JR Stephenson, II Leavy, CE Strickland, DH Bacon, NP Qafoku, and RJ Serne. 2015. Technetium, Iodine, and Chromium Adsorption/Desorption Kd Values for Vadose Zone Pore Water, ILAW Glass, and Cast Stone Leachates Contacting an IDF Sand Sequence, PNNL-24683, Pacific Northwest National Laboratory, Richland, WA

Lee WJ and B Batchelor. 2003. "Reductive capacity of natural reductants.” Environmental Science \& Technology 37:535-541.

Mann FM, KC Burgard, WR Root, RP Puigh, SH Finfrock, R Khaleel, DH Bacon, EJ Freeman, BP McGrail, SK Wurstner, and PE LaMont. 2001. Hanford Immobilization Low-Activity Tank Waste Performance Assessment: 2001 Version. DOE/ORP-2000-24, US Department of Energy, Office of River Protection, Richland, WA.

Mann FM, RJ Puigh, SH Finfrock, R Khaleel, and MI Wood. 2003. Integrated Disposal Facility Risk Assessment. RPP-15834, Rev. 0, CH2M Hill Hanford Group, Inc., Richland, WA.

Mattigod SV, JH Westsik, Jr., CW Chung, MJ Lindberg, and KE Parker. 2011. Waste Acceptance Testing of Secondary Waste Forms: Cast Stone, Ceramicrete and DuraLith. PNNL-20632, Pacific Northwest National Laboratory, Richland, Washington.

McGrail BP, DH Bacon, WL Ebert, and KP Saripalli. 2000. A Strategy to Conduct an Analysis of the Long-Term Performance of Low-Activity Waste Glass in a Shallow Subsurface Disposal System at Hanford. PNNL-11834, Rev. 1, Pacific Northwest National Laboratory, Richland, Washington.

Mehta PK and PJM Monteiro. 2006. Concrete: Microstructure, Properties, and Materials. Third edition, McGraw Hill.

Mindess S, JF Young, and D Darwin. 2003. Concrete. Second edition, Prentice Hall.

Neeway JJ, N Qafoku, RJ Serne, AR Lawter, JR Stephenson, WW Lukens, and JH Westsik, Jr. 2015. Evaluation of Technetium Getters to Improve the Performance of Cast Stone. PNNL-23667 Rev. 1;EMSP-RPT-026 Rev1, Pacific Northwest National Laboratory, Richland, WA.

NQA-1-2008. 2008. Quality Assurance Requirements for Nuclear Facility Applications. The American Society of Mechanical Engineers, New York, New York.

NQA-1a-2009 Addendum. 2009. Quality Assurance Requirements for Nuclear Facility Applications. The American Society of Mechanical Engineers, New York, New York.

Oblath SB. 1989. "Leaching from Solidified Waste Forms under Saturated and Unsaturated Conditions.” Environmental Science and Technology 23:1,098-1,102.

ORP_Office of River Protection. 2014. River Protection Project System Plan. ORP-11242 Revision 7, U.S. Department of Energy, Office of River Protection, Richland, Washington. 
Pabalan RT, FP Glasser, DA Pickett, GR Walter, S Biswas, MR Juckett, LM Sabido, and JL Myers. 2009. Review of Literature and Assessment of Factors Relevant to Performance of Grouted Systems for Radioactive Waste Disposal. CNWRA 2009-001, Center for Nuclear Waste Regulatory Analyses, San Antonio, Texas.

Pabalan RT, GW Alexander, DJ Waiting, and CS Barr. 2012. "Experimental Study of Contaminant Release from Reducing Grout.” International Workshop NUCPERF 2012: Long-Term Performance of Cementitious Barriers and Reinforced Concrete in Nuclear Power Plant and Radioactive Waste Storage and Disposal (RILEM EVENT TC 226-CNM AND EFC EVENT 351), EPJ Web of Conferences, Vol. 56, Article 01010.

Phifer MA, MR Millings, and GP Flach. 2006. Hydraulic Property Data Package for the E-Area and Z-Area Soils, Cementitious Materials, and Waste Zones. WSRC-STI-2006-00198, Rev. 0, Westinghouse Savannah River Company, Aiken, South Carolina.

Pierce EM, BP McGrail, EA Rodriguez, HT Schaef, KP Saripalli, RJ Serne, KM Krupka, PF Martin, SR Baum, KN Geiszler, LR Reed, and WJ Shaw. 2004. Waste Form Release Data Package for the 2005 Integrated Disposal Facility Performance Assessment. PNNL-14805, Pacific Northwest National Laboratory, Richland, Washington.

Pierce EM, W Um, KJ Cantrell, MM Valenta, JH Westsik, Jr., RJ Serne, and KE Parker. 2010. Secondary Waste Form Screening Test Results - Cast Stone and Alkali Alumino-Silicate Geopolymer. PNNL-19505, Pacific Northwest National Laboratory, Richland, Washington.

PNNL—Pacific Northwest National Laboratory. 2009. Hanford Site Secondary Waste Roadmap. PNNL-18196, Pacific Northwest National Laboratory, Richland, WA.

Qafoku N, JJ Neeway, AR Lawter, TG Levitskaia, RJ Serne, JH Westsik, Jr, and MMV Snyder. 2015. Technetium and Iodine Getters to Improve Cast Stone Performance. PNNL-23282 Rev. 1, Pacific Northwest National Laboratory, Richland, WA.

Ramsey AA and RA Robbins. 2012. Secondary Liquid Waste Treatment Cast Stone Technology Development Plan. RPP-51790, Washington River Protection Solutions, Richland, Washington.

Reardon EJ. 1992. "Problems and Approaches to the Prediction of the Chemical Composition in Cement/Water Systems.” Waste Management 12:221-239.

Rockhold ML, ZF Zhang, PD Meyer, and JN Tomle. 2015. Physical, Hydraulic, and Transport Properties of Sediments and Engineered Materials Associated with Hanford Immobilized Low-Activity Waste. PNNL-23711, Pacific Northwest National Laboratory, Richland, WA.

Roe N, and G Parker. 2012. Value Engineering Report for Secondary Liquid Waste Treatment Project. RPP-RPT-51127, ARES Corporation for Washington River Protection Solutions, Richland, WA.

RPP—River Protection Program. 2005. Integrated Disposal Facility Waste Acceptance Criteria. RPP-8402, Rev 1, River Protection Program, U.S. Department of Energy, Richland, Washington. 
Seaman JC and DI Kaplan. 2010. Chloride, Chromate, Silver, Thallium, and Uranium Sorption to SRS Soils, Sediments, and Cementitious Materials. SRNL-STI-2010-00493, Rev. 0, Savannah River Site, Aiken, South Carolina.

Serne RJ and JH Westsik, Jr. 2011. Data Package for Secondary Waste Form Down-Selection—Cast Stone. PNNL-20706, Pacific Northwest National Laboratory, Richland, WA.

Serne, RJ, JH Westsik, Jr, BD Williams, HB Jung, and G Wang. 2015. Extended Leach Testing of Simulated LAW Cast Stone Monoliths. PNNL-24297, Pacific Northwest National Laboratory, Richland, WA.

SRR CWDA—SRR Closure \& Waste Disposal Authority. 2009. Performance Assessment for the Saltstone Disposal Facility at the Savannah River Site. SRR-CWDA-2009-00017, Revision 0, Savannah River Remediation, Aiken, South Carolina.

SRR CWDA—SRR Closure \& Waste Disposal Authority. 2014. FY2014 Special Analysis for the Saltstone Disposal Facility at the Savannah River Site. SRR-CWDA-2014-00006, Revision 2, Savannah River Remediation, Aiken, South Carolina.

Staub AV, JL Adams, and CH Beheler. 2010. "Saltstone Processing of 0.1 Ci/gal Waste at Savannah River Site.” Proceedings of 2010 Waste Management Symposium 3:2167-2175.

Sundaram SK, J Chun, W Um, KE Parker, CW Chung, JH Westsik Jr, MM Valenta, ML Kimura, SG Pitman, and CA Burns. 2011. Secondary Waste Form Development and Optimization-Cast Stone. PNNL-20159, Rev. 1, Pacific Northwest National Laboratory, Richland, Washington.

Takahashi H. et al. 2009. "3D X-ray CT and Diffusion Measurements to Assess Tortuosity and Constrictivity in a Sedimentary Rock.” In: Diffusion Fundamentals III, diffusion-fundamentals.org 11(89):1-11, (http://www.uni-leipzig.de/diffusion/journal/contents_vol11.html).

Taylor HFW. 1997. Cement Chemistry. Academic Press, Thomas Telford edition.

Um W, MM Valenta, CW Chung, J Yang, MH Engelhard, RJ Serne, KE Parker, G Wang, KJ Cantrell, and JH Westsik, Jr. 2011. Radionuclide Retention Mechanisms in Secondary Waste-Form Testing: Phase II. PNNL-20753, Pacific Northwest National Laboratory, Richland, Washington.

Um W, HB Jung, G Wang, JH Westsik, Jr., and RA Peterson. 2013. Characterization of Technetium Speciation in Cast Stone. PNNL-22977, Pacific Northwest National Laboratory, Richland, Washington.

Um W, J-S Yang, RJ Serne, and JH Westsik Jr. 2015. "Reductive capacity measurement of waste forms for secondary radioactive wastes.” Journal of Nuclear Materials, 467, 251-259.

Um, W, BD Williams, MMV Snyder, and G Wang. 2016. Liquid Secondary Waste Grout Formulation and Waste Form Qualification. (In preparation) PNNL-25129, Pacific Northwest National Laboratory, Richland, WA.

van Brakel J and PM Heertjes. 1974. "Analysis of Diffusion in Macroporous Media in Terms of a Porosity, a Tortuosity, and a Constrictivity Factor.” Int. J. Heat and Mass Transfer 17:1093-1103. 
van Genuchten MT. 1980. “A Closed-Form Equation for Predicting the Hydraulic Conductivity of Unsaturated Soils.” Soil Science Society of America Journal 44:892-898.

Wellman DM, SV Mattigod, BW Arey, MI Wood, and SW Forrester. 2007. "Experimental limitations regarding the formation and characterization of uranium-mineral phases in concrete waste forms." Cement and Concrete Research 37(2):151-160.

Westsik JH, Jr. and RJ Serne. 2012. Secondary Waste Cast Stone Waste Form Qualification Testing Plan. PNNL-21656 Rev. 1, Pacific Northwest National Laboratory, Richland, Washington.

Westsik JH, Jr., GF Piepel, MJ Lindberg, PG Heasler, TM Mercier, RL Russell, A Cozzi, WE Daniel, Jr., RE Eibling, EK Hansen, MM Reigel, and DJ Swanberg. 2013. Supplemental Immobilization of Hanford Low-Activity Waste: Cast Stone Screening Tests. PNNL-22747, SRNL-STI-2013-00465, Pacific Northwest National Laboratory, Richland, Washington.

Wilhite EL, CA Langton, HF Sturm, RL Hooker, and ES Occhipinti. 1988. Saltstone Processing Startup at the Savannah River Plant. DP-MS-87-172, E.I. du Pont de Nemours and Company, Savannah River Laboratory, Aiken, SC.

Yabusaki SB, RJ Serne, ML Rockhold, G Wang, and JH Westsik, Jr. 2015. Technical Approach for Determining Key Parameters Needed for Modeling the Performance of Cast Stone for the Integrated Disposal Facility Performance Assessment. PNNL-24022, Pacific Northwest National Laboratory, Richland, Washington. 
Appendix A

Summary Data on Tc Effective Diffusivity Studies 



\section{Appendix A}

\section{Summary Data on Tc Effective Diffusivity Studies}

Table A.1. Tc Effective Diffusivities from Um et al. 2016

\begin{tabular}{|c|c|c|c|c|c|c|c|c|c|c|c|c|c|c|c|c|c|c|c|c|}
\hline Um et al. 2016 & & & & & & & & & & & & & DIW & DIW & DIW & & VZPW & VZPW & VZPW & \\
\hline Test \# & Replicate & Simulant & $\begin{array}{l}\text { Sodium } \\
\text { Molarity }\end{array}$ & $\begin{array}{l}\text { Water-to- } \\
\text { Dry Mix } \\
\text { Ratio }\end{array}$ & $\begin{array}{l}\text { Dry Blend } \\
\text { Addition }\end{array}$ & Dry Materials & Fly Ash & BFS & Filler & Getter & WRA & Duration & $\begin{array}{c}\begin{array}{c}D_{\text {eff }} \\
\left(\mathrm{cm}^{2} / \mathrm{s}\right)\end{array}\end{array}$ & $\begin{array}{c}D_{\text {eff }} \\
\left(\mathrm{cm}^{2} / \mathrm{s}\right)\end{array}$ & Average & $\begin{array}{l}\text { Replicate } \\
\text { Average }\end{array}$ & $\begin{array}{c}D_{\text {eff }} \\
\left(\mathrm{cm}^{2} / \mathrm{s}\right)\end{array}$ & $\begin{array}{c}D_{e f f} \\
\left(\mathrm{~cm}^{2} / \mathrm{s}\right)\end{array}$ & Average & $\begin{array}{l}\text { Replicate } \\
\text { Average }\end{array}$ \\
\hline 1 & - & $242-\mathrm{A}$ & 0.14 & 0.5 & $20 \%, 35 \%, 45 \%$ & lime, OPC, BFS & - & NW & - & - & 3030 & 140 & 4.34E-15 & 3.42E-15 & $3.88 \mathrm{E}-15$ & - & 3.71E-15 & 4.37E-15 & $4.04 \mathrm{E}-15$ & - \\
\hline 2 & Rep 2,7 & ERDF & 0.42 & 0.5 & $20 \%, 35 \%, 45 \%$ & lime, OPC, BFS & - & NW & - & - & 3030 & 140 & 5.33E-14 & $1.83 \mathrm{E}-13$ & $1.18 \mathrm{E}-13$ & $1.66 \mathrm{E}-13$ & $5.91 \mathrm{E}-14$ & 6.36E-14 & 6.14E-14 & $5.96 \mathrm{E}-14$ \\
\hline 3 & - & WTP & 1.5 & 0.5 & $20 \%, 35 \%, 45 \%$ & lime, OPC, BFS & - & NW & - & - & 3030 & 140 & $1.47 \mathrm{E}-14$ & $1.53 \mathrm{E}-14$ & $1.50 \mathrm{E}-14$ & - & 4.75E-15 & 6.53E-15 & $5.64 \mathrm{E}-15$ & - \\
\hline 4 & - & 242-A & 0.14 & 0.6 & $20 \%, 35 \%, 45 \%$ & lime, OPC, BFS & - & NW & - & - & 3030 & 140 & $2.50 \mathrm{E}-13$ & 3.97E-13 & $3.23 \mathrm{E}-13$ & - & 7.33E-14 & $6.75 \mathrm{E}-14$ & $7.04 \mathrm{E}-14$ & - \\
\hline 5 & - & ERDF & 0.42 & 0.6 & $20 \%, 35 \%, 45 \%$ & lime, OPC, BFS & - & NW & - & - & 3030 & 140 & $1.21 \mathrm{E}-13$ & 4.89E-14 & $8.48 \mathrm{E}-14$ & - & $1.17 \mathrm{E}-13$ & $1.21 \mathrm{E}-13$ & $1.19 \mathrm{E}-13$ & - \\
\hline 6 & Rep 6,8 & WTP & 1.5 & 0.6 & $20 \%, 35 \%, 45 \%$ & lime, OPC, BFS & - & NW & - & - & 3030 & 140 & 1.30E-12 & 2.27E-12 & $1.79 \mathrm{E}-12$ & $1.12 \mathrm{E}-12$ & $3.74 \mathrm{E}-12$ & $2.55 \mathrm{E}-12$ & $3.14 \mathrm{E}-12$ & 2.03E-12 \\
\hline 7 & Rep 2,7 & ERDF & 0.42 & 0.5 & $20 \%, 35 \%, 45 \%$ & lime, OPC, BFS & & NW & - & - & 3030 & 140 & $2.45 \mathrm{E}-13$ & $1.84 \mathrm{E}-13$ & $2.15 \mathrm{E}-13$ & $1.66 \mathrm{E}-13$ & $6.54 \mathrm{E}-14$ & $5.01 \mathrm{E}-14$ & $5.78 \mathrm{E}-14$ & $5.96 \mathrm{E}-14$ \\
\hline 8 & Rep 6,8 & WTP & 1.5 & 0.6 & $20 \%, 35 \%, 45 \%$ & lime, OPC, BFS & - & NW & - & - & 3030 & 140 & 6.06E-13 & 3.18E-13 & 4.62E-13 & $1.12 \mathrm{E}-12$ & $9.88 \mathrm{E}-13$ & 8.39E-13 & $9.13 \mathrm{E}-13$ & $2.03 \mathrm{E}-12$ \\
\hline 9 & - & $242-A$ & 0.14 & 0.5 & $20 \%, 10 \%, 70 \%$ & lime, OPC, BFS & - & NW & - & - & 3030 & 140 & $8.20 \mathrm{E}-14$ & 7.09E-14 & 7.64E-14 & - & 3.79E-15 & 3.63E-16 & 3.71E-15 & - \\
\hline 10 & - & WTP & 1.5 & 0.5 & $20 \%, 10 \%, 70 \%$ & lime, OPC, BFS & - & NW & - & - & 3030 & 140 & $9.50 \mathrm{E}-14$ & 7.24E-14 & 8.37E-14 & - & 4.78E-15 & 4.97E-15 & $4.88 \mathrm{E}-15$ & - \\
\hline 11 & - & WTP & 1.5 & 0.6 & $20 \%, 35 \%, 45 \%$ & OPC, FA, BFS & High Ca & NW & Хурех & - & 3030 & 140 & $3.80 \mathrm{E}-14$ & 7.61E-14 & $5.71 \mathrm{E}-14$ & - & $3.26 \mathrm{E}-15$ & 3.85E-15 & 3.56E-15 & - \\
\hline 12 & - & 242-A & 0.14 & 0.6 & $20 \%, 35 \%, 45 \%$ & OPC, FA, BFS & High Ca & NW & Хурех & - & 3030 & 140 & $1.20 \mathrm{E}-12$ & 2.45E-12 & $1.83 \mathrm{E}-12$ & - & $1.58 \mathrm{E}-13$ & 4.29E-14 & $1.00 \mathrm{E}-13$ & - \\
\hline 13 & - & WTP & 1.5 & 0.6 & $8 \%, 45 \%, 47 \%$ & OPC, FA, BFS & High Ca & NW & - & - & 3030 & 140 & $2.21 \mathrm{E}-11$ & $1.26 \mathrm{E}-11$ & $1.73 \mathrm{E}-11$ & - & $1.81 \mathrm{E}-13$ & 2.53E-14 & $1.03 \mathrm{E}-13$ & - \\
\hline 14 & - & $\begin{array}{l}\text { 242-A } \\
+ \text { +ERDF }\end{array}$ & 0.28 & 0.5 & $20 \%, 35 \%, 45 \%$ & lime, OPC, BFS & - & NW & - & $\begin{array}{c}- \\
\text { Sn }\end{array}$ & 3030 & 140 & 7.82E-14 & 5.51E-14 & 6.66E-14 & - & $1.48 \mathrm{E}-14$ & 1.66E-14 & $1.57 \mathrm{E}-14$ & - \\
\hline 15 & - & WTP & 1.5 & 0.5 & $20 \%, 35 \%, 45 \%$ & lime, OPC, BFS & - & NW & - & Apatite & 3030 & 140 & $1.34 \mathrm{E}-13$ & 1.60E-13 & $1.47 \mathrm{E}-13$ & - & $2.18 \mathrm{E}-14$ & $2.74 \mathrm{E}-14$ & $2.46 \mathrm{E}-14$ & - \\
\hline 16 & - & WTP & 1.5 & 0.5 & $20 \%, 35 \%, 45 \%$ & lime, OPC, BFS & - & NW & - & $\begin{array}{c}\mathrm{SnCl}_{2} \\
\mathrm{Sn}\end{array}$ & 3030 & 140 & 1.95E-12 & 2.19E-12 & 2.07E-12 & - & $1.51 \mathrm{E}-13$ & $9.20 \mathrm{E}-14$ & $1.22 \mathrm{E}-13$ & - \\
\hline 17 & - & WTP & 1.5 & 0.5 & $20 \%, 10 \%, 70 \%$ & lime, OPC, BFS & - & NW & Хурех & Apatite & 3030 & 140 & 2.13E-13 & 2.46E-13 & $2.30 \mathrm{E}-13$ & - & 3.47E-15 & 2.93E-15 & $3.20 \mathrm{E}-15$ & - \\
\hline 18 & - & WTP & 1.5 & 0.5 & $20 \%, 10 \%, 70 \%$ & lime, OPC, BFS & - & NW & Хурех & $\mathrm{SnCl}_{2}$ & 3030 & 140 & $1.56 \mathrm{E}-12$ & $1.83 \mathrm{E}-12$ & $1.70 \mathrm{E}-12$ & - & $4.04 \mathrm{E}-15$ & 3.73E-15 & 3.89E-15 & - \\
\hline
\end{tabular}

Treatment and Immobilization Plant 
Table A.2. Tc Effective Diffusivities from Westsik et al. 2013

\begin{tabular}{|c|c|c|c|c|c|c|c|c|c|c|c|c|c|}
\hline Test \# & Replicate & Simulant & Sodium Molarity & Water-to-Dry Mix Ratio & Dry Blend Addition & Dry Materials & Fly Ash & BFS & Duration & $D_{\text {eff }}\left(\mathrm{cm}^{2} / \mathrm{s}\right)$ & $D_{\text {eff }}\left(\mathrm{cm}^{2} / \mathrm{s}\right)$ & Average & Replicate Average \\
\hline 1 & - & High $\mathrm{SO}_{4}$ & 5 & 0.4 & $8 \%, 45 \%, 47 \%$ & OPC, FA, BFS & Low Ca & NW & 91 & $4.72 \mathrm{E}-11$ & 4.61E-11 & $4.66 \mathrm{E}-11$ & - \\
\hline 2 & Rep 2,13 & Average & 5 & 0.6 & $8 \%, 45 \%, 47 \%$ & OPC, FA, BFS & Low Ca & $\mathrm{SE}$ & 91 & 5.66E-11 & 4.44E-11 & 5.05E-11 & $6.20 \mathrm{E}-11$ \\
\hline 3 & Rep 3,22 & Average & 7.8 & 0.6 & $8 \%, 45 \%, 47 \%$ & OPC, FA, BFS & High Ca & SE & 91 & 3.36E-11 & 3.08E-11 & $3.22 \mathrm{E}-11$ & 2.79E-11 \\
\hline 4 & - & High Al & 5 & 0.4 & $8 \%, 45 \%, 47 \%$ & OPC, FA, BFS & High Ca & SE & 91 & $2.52 \mathrm{E}-11$ & 3.22E-11 & 2.87E-11 & - \\
\hline 5 & - & Average & 7.8 & 0.4 & $8 \%, 45 \%, 47 \%$ & OPC, FA, BFS & High Ca & NW & 91 & $5.72 \mathrm{E}-11$ & 5.62E-11 & $5.67 \mathrm{E}-11$ & - \\
\hline 6 & - & Average & 7.8 & 0.4 & $8 \%, 45 \%, 47 \%$ & OPC, FA, BFS & Low Ca & NW & 91 & 1.30E-10 & $1.38 \mathrm{E}-10$ & $1.34 \mathrm{E}-10$ & - \\
\hline 7 & Rep 7,14 & $\mathrm{High} \mathrm{SO}_{4}$ & 7.8 & 0.4 & $8 \%, 45 \%, 47 \%$ & OPC, FA, BFS & Low Ca & $\mathrm{SE}$ & 91 & 7.55E-12 & $8.20 \mathrm{E}-12$ & 7.88E-12 & 8.21E-12 \\
\hline 8 & - & SST Blend & 5 & 0.4 & $8 \%, 45 \%, 47 \%$ & OPC, FA, BFS & Low Ca & NW & 91 & $1.89 \mathrm{E}-10$ & $1.88 \mathrm{E}-10$ & $1.88 \mathrm{E}-10$ & - \\
\hline 9 & - & High Al & 7.8 & 0.6 & $8 \%, 45 \%, 47 \%$ & OPC, FA, BFS & High Ca & SE & 91 & 3.05E-11 & 2.87E-11 & 2.96E-11 & - \\
\hline 10 & - & $\mathrm{High} \mathrm{SO}_{4}$ & 5 & 0.6 & $8 \%, 45 \%, 47 \%$ & OPC, FA, BFS & High Ca & NW & 91 & $1.08 \mathrm{E}-10$ & $1.09 \mathrm{E}-10$ & $1.09 \mathrm{E}-10$ & - \\
\hline 11 & - & High Al & 7.8 & 0.6 & $8 \%, 45 \%, 47 \%$ & OPC, FA, BFS & Low Ca & NW & 91 & $1.14 \mathrm{E}-10$ & $1.24 \mathrm{E}-10$ & $1.19 \mathrm{E}-10$ & - \\
\hline 12 & - & SST Blend & 5 & 0.6 & $8 \%, 45 \%, 47 \%$ & OPC, FA, BFS & High Ca & SE & 91 & 3.96E-11 & 3.96E-11 & 3.96E-11 & - \\
\hline 13 & Rep 2,13 & Average & 5 & 0.6 & $8 \%, 45 \%, 47 \%$ & OPC, FA, BFS & Low Ca & SE & 91 & 7.94E-11 & $6.75 \mathrm{E}-11$ & 7.35E-11 & $6.20 \mathrm{E}-11$ \\
\hline 14 & Rep 7,14 & $\mathrm{High} \mathrm{SO}_{4}$ & 7.8 & 0.4 & $8 \%, 45 \%, 47 \%$ & OPC, FA, BFS & Low Ca & SE & 91 & 7.51E-12 & $9.58 \mathrm{E}-12$ & 8.54E-12 & 8.21E-12 \\
\hline 15 & Rep 15,25 & $\mathrm{High} \mathrm{SO}_{4}$ & 7.8 & 0.4 & $8 \%, 45 \%, 47 \%$ & OPC, FA, BFS & High Ca & NW & 91 & 3.60E-11 & 3.84E-11 & 3.72E-11 & 3.73E-11 \\
\hline 16 & - & SST Blend & 7.8 & 0.4 & $8 \%, 45 \%, 47 \%$ & OPC, FA, BFS & High Ca & NW & 91 & $1.31 \mathrm{E}-10$ & $1.41 \mathrm{E}-10$ & $1.36 \mathrm{E}-10$ & - \\
\hline 17 & - & High Al & 5 & 0.6 & $8 \%, 45 \%, 47 \%$ & OPC, FA, BFS & Low Ca & SE & 91 & 1.67E-10 & $1.57 \mathrm{E}-10$ & $1.62 \mathrm{E}-10$ & - \\
\hline 18 & - & SST Blend & 7.8 & 0.4 & $8 \%, 45 \%, 47 \%$ & OPC, FA, BFS & Low Ca & SE & 91 & 5.65E-12 & 6.39E-12 & 6.02E-12 & - \\
\hline 19 & - & High Al & 7.8 & 0.4 & $8 \%, 45 \%, 47 \%$ & OPC, FA, BFS & Low Ca & NW & 91 & 4.59E-11 & 4.46E-11 & 4.53E-11 & - \\
\hline 20 & - & Average & 5 & 0.4 & $8 \%, 45 \%, 47 \%$ & OPC, FA, BFS & High Ca & SE & 91 & 3.48E-11 & 3.17E-11 & 3.33E-11 & - \\
\hline 21 & Rep 21,26 & High $\mathrm{SO}_{4}$ & 7.8 & 0.6 & $8 \%, 45 \%, 47 \%$ & OPC, FA, BFS & Low Ca & NW & 91 & $9.41 \mathrm{E}-11$ & 1.72E-10 & $1.33 \mathrm{E}-10$ & $1.35 \mathrm{E}-10$ \\
\hline 22 & Rep 3,22 & Average & 7.8 & 0.6 & $8 \%, 45 \%, 47 \%$ & OPC, FA, BFS & High Ca & SE & 91 & 2.35E-11 & 2.37E-11 & 2.36E-11 & 2.79E-11 \\
\hline 23 & - & SST Blend & 7.8 & 0.6 & $8 \%, 45 \%, 47 \%$ & OPC, FA, BFS & Low Ca & NW & 91 & $1.02 \mathrm{E}-09$ & 6.96E-10 & 8.56E-10 & - \\
\hline 24 & - & High Al & 5 & 0.6 & $8 \%, 45 \%, 47 \%$ & OPC, FA, BFS & High Ca & NW & 91 & 5.99E-11 & 6.42E-11 & 6.21E-11 & - \\
\hline 25 & Rep 15,25 & $\mathrm{High} \mathrm{SO}_{4}$ & 7.8 & 0.4 & $8 \%, 45 \%, 47 \%$ & OPC, FA, BFS & High Ca & NW & 91 & 5.34E-11 & $2.14 \mathrm{E}-11$ & 3.74E-11 & 3.73E-11 \\
\hline 26 & Rep 21,26 & $\mathrm{High} \mathrm{SO}_{4}$ & 7.8 & 0.6 & $8 \%, 45 \%, 47 \%$ & OPC, FA, BFS & Low Ca & NW & 91 & 1.36E-10 & 1.39E-10 & $1.38 \mathrm{E}-10$ & $1.35 \mathrm{E}-10$ \\
\hline
\end{tabular}


Table A.3. Tc Effective Diffusivities from Westsik et al. 2013 and Serne et al. 2015

\begin{tabular}{|c|c|c|c|c|c|c|c|c|c|c|c|c|c|c|c|c|c|}
\hline & & & & & & & & & & & & & & Extended & & Archive & Archive \\
\hline & & & & & & & & & & & & & & DIW & & DIW & VZPW \\
\hline Test \# & Replicate & $\begin{array}{l}\text { Simulant } \\
\text { Sim }\end{array}$ & Sodium Molarity & Water-to-Dry Mix Ratio & Dry Blend Addition & Dry Materials & Fly Ash & BFS & Duration & $D_{\text {eff }}\left(\mathrm{cm}^{2} / \mathrm{s}\right)$ & $D_{\text {eff }}\left(\mathrm{cm}^{2} / \mathrm{s}\right)$ & Average & Duration & $D_{\text {eff }}\left(\mathrm{cm}^{2} / \mathrm{s}\right)$ & Duration & $D_{\text {eff }}\left(\mathrm{cm}^{2} / \mathrm{s}\right)$ & $D_{\text {eff }}\left(\mathrm{cm}^{2} / \mathrm{s}\right)$ \\
\hline 1 & - & High $\mathrm{SO}_{4}$ & 5 & 0.4 & $8 \%, 45 \%, 47 \%$ & OPC, FA, BFS & Low Ca & NW & 91 & $4.72 \mathrm{E}-11$ & 4.61E-11 & 4.66E-11 & - & - & - & - & - \\
\hline 2 & Rep 2,13 & Average & 5 & 0.6 & $8 \%, 45 \%, 47 \%$ & OPC, FA, BFS & Low Ca & SE & 91 & $5.66 \mathrm{E}-11$ & $4.44 \mathrm{E}-11$ & 5.05E-11 & - & - & - & - & - \\
\hline 3 & Rep 3,22 & Average & 7.8 & 0.6 & $8 \%, 45 \%, 47 \%$ & OPC, FA, BFS & High Ca & $\mathrm{SE}$ & 91 & 3.36E-11 & $3.08 \mathrm{E}-11$ & 3.22E-11 & - & - & 427 & $9.47 \mathrm{E}-11$ & $2.61 \mathrm{E}-12$ \\
\hline 4 & - & High Al & 5 & 0.4 & $8 \%, 45 \%, 47 \%$ & OPC, FA, BFS & High Ca & $\mathrm{SE}$ & 91 & 2.52E-11 & $3.22 \mathrm{E}-11$ & 2.87E-11 & - & - & - & . & - \\
\hline 5 & - & Average & 7.8 & 0.4 & $8 \%, 45 \%, 47 \%$ & OPC, FA, BFS & High Ca & NW & 91 & $5.72 \mathrm{E}-11$ & $5.62 \mathrm{E}-11$ & $5.67 \mathrm{E}-11$ & 609 & 3.87E-11 & 427 & 4.16E-11 & $1.23 \mathrm{E}-12$ \\
\hline 6 & - & Average & 7.8 & 0.4 & $8 \%, 45 \%, 47 \%$ & OPC, FA, BFS & Low Ca & NW & 91 & $1.30 \mathrm{E}-10$ & $1.38 \mathrm{E}-10$ & $1.34 \mathrm{E}-10$ & - & - & - & - & - \\
\hline 7 & Rep 7,14 & $\mathrm{High} \mathrm{SO}_{4}$ & 7.8 & 0.4 & $8 \%, 45 \%, 47 \%$ & OPC, FA, BFS & Low Ca & $\mathrm{SE}$ & 91 & 7.55E-12 & $8.20 \mathrm{E}-12$ & $7.88 \mathrm{E}-12$ & - & - & - & - & . \\
\hline 8 & - & SST Blend & 5 & 0.4 & $8 \%, 45 \%, 47 \%$ & OPC, FA, BFS & Low Ca & NW & 91 & $1.89 \mathrm{E}-10$ & $1.88 \mathrm{E}-10$ & $1.88 \mathrm{E}-10$ & 609 & $1.54 \mathrm{E}-10$ & 427 & $1.26 \mathrm{E}-10$ & 4.33E-12 \\
\hline 9 & - & High Al & 7.8 & 0.6 & $8 \%, 45 \%, 47 \%$ & OPC, FA, BFS & High Ca & $\mathrm{SE}$ & 91 & 3.05E-11 & $2.87 \mathrm{E}-11$ & 2.96E-11 & - & - & - & - & - \\
\hline 10 & - & High $\mathrm{SO}_{4}$ & 5 & 0.6 & $8 \%, 45 \%, 47 \%$ & OPC, FA, BFS & High Ca & NW & 91 & $1.08 \mathrm{E}-10$ & $1.09 \mathrm{E}-10$ & $1.09 \mathrm{E}-10$ & 609 & $1.14 \mathrm{E}-10$ & 427 & 8.35E-11 & $5.28 \mathrm{E}-12$ \\
\hline 11 & - & High Al & 7.8 & 0.6 & $8 \%, 45 \%, 47 \%$ & OPC, FA, BFS & Low Ca & NW & 91 & $1.14 \mathrm{E}-10$ & $1.24 \mathrm{E}-10$ & 1.19E-10 & - & - & - & - & - \\
\hline 12 & - & SST Blend & 5 & 0.6 & $8 \%, 45 \%, 47 \%$ & OPC, FA, BFS & High Ca & $\mathrm{SE}$ & 91 & $3.96 \mathrm{E}-11$ & 3.96E-11 & 3.96E-11 & - & - & - & - & - \\
\hline 13 & Rep 2,13 & Average & 5 & 0.6 & $8 \%, 45 \%, 47 \%$ & OPC, FA, BFS & Low Ca & $\mathrm{SE}$ & 91 & 7.94E-11 & $6.75 \mathrm{E}-11$ & 7.35E-11 & 609 & 8.46E-11 & 427 & $9.31 \mathrm{E}-11$ & $1.44 \mathrm{E}-11$ \\
\hline 14 & Rep 7,14 & High $\mathrm{SO}_{4}$ & 7.8 & 0.4 & $8 \%, 45 \%, 47 \%$ & OPC, FA, BFS & Low Ca & $\mathrm{SE}$ & 91 & 7.51E-12 & $9.58 \mathrm{E}-12$ & 8.54E-12 & 609 & $9.57 \mathrm{E}-12$ & 427 & 7.95E-12 & $2.34 \mathrm{E}-12$ \\
\hline 15 & Rep 15,25 & $\mathrm{High} \mathrm{SO}_{4}$ & 7.8 & 0.4 & $8 \%, 45 \%, 47 \%$ & OPC, FA, BFS & High Ca & NW & 91 & $3.60 \mathrm{E}-11$ & $3.84 \mathrm{E}-11$ & 3.72E-11 & 604 & $3.30 \mathrm{E}-11$ & 427 & 3.44E-11 & $1.23 \mathrm{E}-12$ \\
\hline 16 & - & SST Blend & 7.8 & 0.4 & $8 \%, 45 \%, 47 \%$ & OPC, FA, BFS & High Ca & NW & 91 & $1.31 \mathrm{E}-10$ & $1.41 \mathrm{E}-10$ & 1.36E-10 & 604 & $1.48 \mathrm{E}-10$ & 427 & $1.52 \mathrm{E}-10$ & 2.33E-11 \\
\hline 17 & - & High Al & 5 & 0.6 & $8 \%, 45 \%, 47 \%$ & OPC, FA, BFS & Low Ca & $\mathrm{SE}$ & 91 & $1.67 \mathrm{E}-10$ & $1.57 \mathrm{E}-10$ & $1.62 \mathrm{E}-10$ & 604 & $2.64 \mathrm{E}-10$ & 427 & 2.47E-10 & 2.19E-11 \\
\hline 18 & - & SST Blend & 7.8 & 0.4 & $8 \%, 45 \%, 47 \%$ & OPC, FA, BFS & Low Ca & $\mathrm{SE}$ & 91 & $5.65 \mathrm{E}-12$ & 6.39E-12 & $6.02 \mathrm{E}-12$ & 604 & $2.26 \mathrm{E}-11$ & 427 & 2.85E-11 & 5.56E-12 \\
\hline 19 & - & High Al & 7.8 & 0.4 & $8 \%, 45 \%, 47 \%$ & OPC, FA, BFS & Low Ca & NW & 91 & 4.59E-11 & 4.46E-11 & 4.53E-11 & . & - & - & - & . \\
\hline 20 & - & Average & 5 & 0.4 & $8 \%, 45 \%, 47 \%$ & OPC, FA, BFS & High Ca & $\mathrm{SE}$ & 91 & $3.48 \mathrm{E}-11$ & 3.17E-11 & 3.33E-11 & - & - & - & - & - \\
\hline 21 & Rep 21,26 & High $\mathrm{SO}_{4}$ & 7.8 & 0.6 & $8 \%, 45 \%, 47 \%$ & OPC, FA, BFS & Low Ca & NW & 91 & $9.41 \mathrm{E}-11$ & $1.72 \mathrm{E}-10$ & $1.33 \mathrm{E}-10$ & 604 & $2.51 \mathrm{E}-10$ & 427 & 2.96E-10 & 6.43E-12 \\
\hline 22 & Rep 3,22 & Average & 7.8 & 0.6 & $8 \%, 45 \%, 47 \%$ & OPC, FA, BFS & High Ca & $\mathrm{SE}$ & 91 & $2.35 \mathrm{E}-11$ & $2.37 \mathrm{E}-11$ & 2.36E-11 & - & - & - & - & - \\
\hline 23 & - & SST Blend & 7.8 & 0.6 & $8 \%, 45 \%, 47 \%$ & OPC, FA, BFS & Low Ca & NW & 91 & $1.02 \mathrm{E}-09$ & $6.96 \mathrm{E}-10$ & 8.56E-10 & - & - & - & - & - \\
\hline 24 & - & High Al & 5 & 0.6 & $8 \%, 45 \%, 47 \%$ & OPC, FA, BFS & High Ca & NW & 91 & 5.99E-11 & $6.42 \mathrm{E}-11$ & $6.21 \mathrm{E}-11$ & 604 & 7.39E-11 & 427 & $9.92 \mathrm{E}-12$ & $6.77 \mathrm{E}-13$ \\
\hline 25 & Rep 15,25 & High $\mathrm{SO}_{4}$ & 7.8 & 0.4 & $8 \%, 45 \%, 47 \%$ & OPC, FA, BFS & High Ca & NW & 91 & $5.34 \mathrm{E}-11$ & $2.14 \mathrm{E}-11$ & 3.74E-11 & - & - & - & - & - \\
\hline 26 & Rep 21,26 & High $\mathrm{SO}_{4}$ & 7.8 & 0.6 & $8 \%, 45 \%, 47 \%$ & OPC, FA, BFS & Low Ca & NW & 91 & $1.36 \mathrm{E}-10$ & $1.39 \mathrm{E}-10$ & $1.38 \mathrm{E}-10$ & - & - & - & - & - \\
\hline
\end{tabular}

Table A.4. Tc Effective Diffusivities from Mattigod et al. (2011)

\begin{tabular}{|c|c|c|c|c|c|c|c|c|c|c|c|}
\hline Test \# & Replicate & Simulant & Sodium Molarity & Water-to-Dry Mix Ratio & Dry Blend Addition & Dry Materials & Fly Ash & BFS & Duration & $D_{\text {eff }}\left(\mathrm{cm}^{2} / \mathrm{s}\right)$ & $D_{\text {eff }}\left(\mathrm{cm}^{2} / \mathrm{s}\right)$ \\
\hline $1315-2 m$ & - & WTP Lo $\mathrm{SO}_{4}$ & 2 & 0.35 & $8 \%, 45 \%, 47 \%$ & OPC, FA, BFS & High Ca & NW & 63 & $7.158 \mathrm{E}-12$ & $5.508 \mathrm{E}-12$ \\
\hline $1315-4 M$ & - & WTP Lo $\mathrm{SO}_{4}$ & 3 & 0.37 & $8 \%, 45 \%, 47 \%$ & OPC, FA, BFS & High Ca & NW & 63 & $1.975 \mathrm{E}-10$ & $1.825 \mathrm{E}-10$ \\
\hline 1315-6M & - & WTP Lo $\mathrm{SO}_{4}$ & 6 & 0.38 & $8 \%, 45 \%, 47 \%$ & OPC, FA, BFS & High Ca & NW & 63 & $8.448 \mathrm{E}-11$ & 1.406E-10 \\
\hline ANS-2M & - & WTP Lo $\mathrm{SO}_{4}$ & 2 & 0.35 & $8 \%, 45 \%, 47 \%$ & OPC, FA, BFS & High Ca & NW & 91 & 3.627E-12 & $2.27 \mathrm{E}-12$ \\
\hline
\end{tabular}



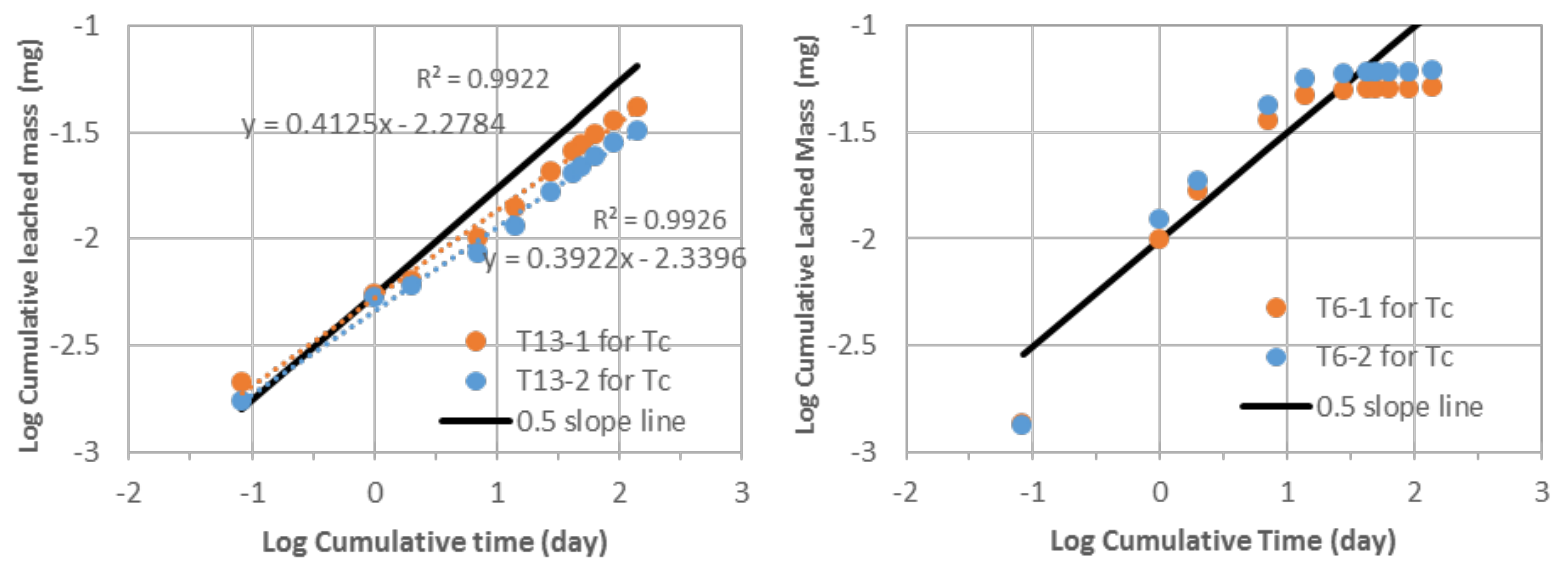

Figure A.1. Logarithm of the Cumulative ${ }^{99}$ Tc Release Plotted vs. the Logarithm of Cumulative Time for Cast Stone T13 Formulation with a Slope of $0.5 \pm 0.15$ (left) and Hydrated Lime Based T6 Formulation with a Sharp Break in Slope (right). 
Table A.5. Replicate Values, Standard Deviations (SDs), and Percent Relative Standard Deviations (\%RSDs) for Effective Diffusion Coefficients from EPA 1315 Leach Tests, Along with Pooled SDs and \%RSDs Using All Replicate Pairs (For Information Only) (From Westsik et al. 2013).

\begin{tabular}{|c|c|c|c|c|c|c|}
\hline \multirow{2}{*}{$\begin{array}{c}\text { Replicate } \\
\text { Pair } \\
\text { Mix \#s } \\
\end{array}$} & \multicolumn{6}{|c|}{ Effective Diffusion Coefficient $\left(\mathrm{cm}^{2} / \mathrm{s}\right)$} \\
\hline & I & Tc & $\mathrm{Na}$ & $\mathrm{NO}_{3}$ & $\mathrm{NO}_{2}$ & $\mathrm{Cr}$ \\
\hline 2 & 7.02E-09 & 5.99E-11 & 6.92E-09 & 6.65E-09 & 7.50E-09 & $8.22 \mathrm{E}-14$ \\
\hline & 8.48E-09 & 8.27E-11 & $6.44 \mathrm{E}-09$ & 8.75E-09 & 7.47E-09 & $5.51 \mathrm{E}-14$ \\
\hline 13 & 1.03E-09 & 1.61E-11 & 3.39E-10 & 1.48E-09 & 2.12E-11 & 1.92E-14 \\
\hline$\%$ RSD & $1.33 E+01$ & $2.26 \mathrm{E}+01$ & $5.08 \mathrm{E}+00$ & $1.93 E+01$ & 2.83E-01 & $2.79 \mathrm{E}+01$ \\
\hline 3 & 4.98E-09 & $3.47 \mathrm{E}-11$ & 4.99E-09 & 4.60E-09 & $5.44 \mathrm{E}-09$ & $1.64 \mathrm{E}-13$ \\
\hline 22 & 4.42E-09 & $2.48 \mathrm{E}-11$ & 4.84E-09 & 4.32E-09 & 4.14E-09 & $1.79 \mathrm{E}-13$ \\
\hline SD & 3.96E-10 & 7.00E-12 & 1.06E-10 & $1.98 E-10$ & 9.19E-10 & 1.06E-14 \\
\hline$\%$ RSD & $8.43 E+00$ & $2.35 E+01$ & $2.16 \mathrm{E}+00$ & $4.44 \mathrm{E}+00$ & $1.92 E+01$ & $6.18 E+00$ \\
\hline 7 & 4.25E-09 & $9.06 \mathrm{E}-12$ & 3.52E-09 & 4.72E-09 & 4.68E-09 & 8.28E-15 \\
\hline 14 & 5.70E-09 & $9.61 \mathrm{E}-12$ & 4.44E-09 & $6.26 \mathrm{E}-09$ & 5.93E-09 & $9.90 \mathrm{E}-15$ \\
\hline SD & 1.03E-09 & 3.89E-13 & 6.51E-10 & 1.09E-09 & 8.84E-10 & 1.15E-15 \\
\hline$\%$ RSD & $2.06 E+01$ & $4.17 E+00$ & $1.63 E+01$ & $1.98 E+01$ & $1.67 E+01$ & $1.26 \mathrm{E}+01$ \\
\hline 15 & 5.67E-09 & 4.62E-11 & 7.33E-09 & 7.01E-09 & 7.17E-09 & $3.16 \mathrm{E}-13$ \\
\hline 25 & 4.87E-09 & $2.88 \mathrm{E}-11$ & 6.86E-09 & 6.99E-09 & 5.80E-09 & $4.02 \mathrm{E}-13$ \\
\hline SD & $5.66 \mathrm{E}-10$ & 1.23E-11 & 3.32E-10 & 1.41E-11 & 9.69E-10 & $6.08 E-14$ \\
\hline \%RSD & $1.07 E+01$ & $3.28 \mathrm{E}+01$ & $4.68 \mathrm{E}+00$ & 2.02E-01 & $1.49 \mathrm{E}+01$ & $1.69 \mathrm{E}+01$ \\
\hline 21 & 1.68E-08 & $9.44 \mathrm{E}-11$ & $1.05 \mathrm{E}-08$ & 1.52E-08 & 1.38E-08 & $1.51 \mathrm{E}-13$ \\
\hline 26 & 7.30E-09 & $1.66 \mathrm{E}-10$ & 8.07E-09 & 7.85E-09 & 7.09E-09 & $1.02 \mathrm{E}-13$ \\
\hline SD & 6.72E-09 & $5.06 E-11$ & 1.72E-09 & $5.20 \mathrm{E}-09$ & 4.74E-09 & 3.46E-14 \\
\hline \%RSD & $5.57 \mathrm{E}+01$ & $3.89 \mathrm{E}+01$ & $1.85 \mathrm{E}+01$ & $4.51 \mathrm{E}+01$ & $4.54 \mathrm{E}+01$ & $2.74 \mathrm{E}+01$ \\
\hline \multicolumn{7}{|l|}{ Pooled $^{(a)}$} \\
\hline SD & 3.09E-09 & $2.46 \mathrm{E}-11$ & 8.50E-10 & 2.47E-09 & 2.24E-09 & $3.28 \mathrm{E}-14$ \\
\hline \%RSD & $2.79 \mathrm{E}+01$ & $2.71 E+01$ & $1.15 E+01$ & $2.37 \mathrm{E}+01$ & $2.42 E+01$ & $2.01 E+01$ \\
\hline
\end{tabular}

(a) Pooled SDs and \%RSDs were calculated by squaring the SDs and \%RSDs, averaging the squared values over the five replicate sets, then taking the square root. The formula is simpler than the general formula because each SD or \%RSD is calculated from the same number of values (two). 

Appendix B

Simulant Compositions 



\section{Appendix B}

\section{Simulant Compositions}

Table B.1. Nominal ETF ${ }^{(a)}$-Treated Waste Compositions (relative molar amount)(Um et al. 2016)

\begin{tabular}{lccc}
\hline $\begin{array}{c}\text { Chemical } \\
\text { Constituents }\end{array}$ & $\begin{array}{c}\text { 242-A } \\
\text { Evaporator } \\
\text { Condensates }\end{array}$ & $\begin{array}{c}\text { ERDF } \\
\text { Leachates }\end{array}$ & $\begin{array}{c}\text { WTP } \\
\text { Condensates }\end{array}$ \\
\hline $\mathrm{NH}_{4}^{+}$ & 0.541 & $-{ }^{(\mathrm{d})}$ & 0.330 \\
\hline $\mathrm{Ca}^{2+}$ & 0.023 & 0.171 & - \\
\hline $\mathrm{Cl}^{-}$ & 0.013 & 0.162 & 0.006 \\
\hline $\mathrm{F}^{-}$ & - & - & 0.001 \\
\hline $\mathrm{Na}^{+}$ & 0.075 & 0.222 & 0.295 \\
\hline $\mathrm{K}^{+}$ & 0.003 & - & - \\
\hline $\mathrm{Mg}^{+}$ & 0.009 & 0.092 & 0.117 \\
\hline $\mathrm{NO}_{3}{ }^{-}$ & - & 0.117 & 0.001 \\
\hline $\mathrm{NO}_{2}{ }^{-}$ & - & - & 0.250 \\
\hline $\mathrm{SO}_{4}{ }^{2-}$ & 0.324 & 0.235 & - \\
\hline $\mathrm{Si}^{4+}$ & 0.011 & - & \\
\hline $\mathrm{Total}^{+}$Moles & 1.0 & 1.0 & \\
\hline $\begin{array}{l}\text { (a) ETF = Effluent Treatment Facility } \\
\text { (b) ERDF = Environmental Restoration Disposal Facility }\end{array}$ \\
$\begin{array}{l}\text { (c) WTP = Hanford Tank Waste Treatment and Immobilization Plant } \\
\text { (d) “-” not reported, and therefore not added to the simulants }\end{array}$ \\
\hline
\end{tabular}


Table B.2. Spike Levels for RCRA Metals, Hazardous Constituents, and Radionuclides in ETF-Treated Waste Simulants (Um et al. 2016)

\begin{tabular}{|c|c|c|c|c|}
\hline Waste Constituent & $\begin{array}{c}\text { 242-A } \\
\text { Evaporator } \\
\text { Condensate }\end{array}$ & $\begin{array}{c}\text { ERDF } \\
\text { Leachates }\end{array}$ & $\begin{array}{l}\text { WTP Off-Gas } \\
\text { Condensates }\end{array}$ & UTS in TCLP Leachate \\
\hline \multicolumn{5}{|c|}{ RCRA Metals } \\
\hline & moles / mole Cl & moles / mole Cl & moles / mole Cl & $\mathrm{mg} / \mathrm{L}$ \\
\hline As & 3.15E-4 & $2.18 \mathrm{E}-4$ & $8.86 \mathrm{E}-5$ & 5.0 \\
\hline $\mathrm{Ba}$ & 4.49E-4 & $\mathrm{ND}^{(\mathrm{a})}$ & $5.42 \mathrm{E}-10$ & 21 \\
\hline $\mathrm{Cd}$ & ND & $2.43 \mathrm{E}-5$ & $2.94 \mathrm{E}-8$ & 0.11 \\
\hline $\mathrm{Cr}$ & $6.94 \mathrm{E}-4$ & $5.24 \mathrm{E}-5$ & ND & 0.60 \\
\hline $\mathrm{Pb}$ & $4.12 \mathrm{E}-5$ & $1.88 \mathrm{E}-3$ & $8.13 \mathrm{E}-6$ & 0.75 \\
\hline $\mathrm{Hg}$ & $3.06 \mathrm{E}-6$ & $1.36 \mathrm{E}-5$ & $2.23 \mathrm{E}-4$ & 0.025 \\
\hline Se & $4.99 \mathrm{E}-5$ & $1.04 \mathrm{E}-4$ & ND & 5.7 \\
\hline $\mathrm{Ag}$ & ND & ND & $1.24 \mathrm{E}-7$ & 0.14 \\
\hline \multicolumn{5}{|c|}{ Underlying Hazardous Constituents } \\
\hline $\mathrm{Sb}$ & ND & $4.48 \mathrm{E}-5$ & $1.26 \mathrm{E}-5$ & 1.15 \\
\hline $\mathrm{Be}$ & ND & ND & ND & 1.22 \\
\hline $\mathrm{Ni}$ & 8.39E-4 & $2.79 \mathrm{E}-4$ & $1.41 \mathrm{E}-8$ & 11 \\
\hline $\mathrm{Tl}$ & $\mathrm{NR}^{(\mathrm{b})}$ & NR & ND & 0.20 \\
\hline \multicolumn{5}{|c|}{ Radionuclides } \\
\hline & $\mathrm{Ci} /$ mole $\mathrm{Na}^{(\mathrm{c})}$ & $\mathrm{Ci} /$ mole $\mathrm{Na}^{(\mathrm{d})}$ & $\mathrm{Ci} /$ mole $\mathrm{Na}^{(\mathrm{e})}$ & - \\
\hline${ }^{99} \mathrm{Tc}$ & $2.04 \mathrm{E}-7$ & $3.78 \mathrm{E}-8$ & $4.67 \mathrm{E}-6$ & - \\
\hline${ }^{129} \mathrm{I}$ & $5.87 \mathrm{E}-9$ & $3.43 \mathrm{E}-10$ & $3.70 \mathrm{E}-9$ & - \\
\hline
\end{tabular}

RCRA $=$ Resource Conservation and Recovery Act

TCLP = Toxicity Characteristic Leaching Procedure

“_” = not considered.

(a) Not detected and thus was not spiked into the simulants

(b) Not reported and thus was not spiked into the simulants

(c) Derived from Evaporator Brine column in Table A-2 of Halgren (2013)

(d) Derived from ERDF Leachate column in Table A-1 of Halgren (2012)

(e) Derived from G-2 model output. (E-mail message from J. Mahoney (Washington River Protection Solutions) to

Renee Russell and Wooyong Um (Pacific Northwest National Laboratory), "EMF Brine Simulant and

Hazardous Constituent Information,” March 3, 2015.) 
Table B.3. Final Low-Activity Waste Simulants for Cast Stone Screening Tests (Westsik et al. 2013)

\begin{tabular}{lcccc}
\hline $\begin{array}{c}\text { Waste } \\
\text { Constituent }\end{array}$ & $\begin{array}{c}\text { SST Blend } \\
\text { Saltcake }\end{array}$ & $\begin{array}{c}\text { HTWOS } \\
\text { Overall } \\
\text { Average }\end{array}$ & $\begin{array}{c}\text { HTWOS } \\
\text { High Al }\end{array}$ & $\begin{array}{c}\text { HTWOS } \\
\text { High SO }\end{array}$ \\
\hline \multicolumn{5}{c}{ Concentration (moles/mole Na) } \\
\hline $\mathrm{Na}$ & 1.000 & 1.000 & 1.000 & 1.000 \\
\hline $\mathrm{K}$ & 0.002 & 0.007 & 0.028 & - \\
\hline $\mathrm{Al}$ & 0.013 & 0.061 & 0.112 & 0.047 \\
\hline $\mathrm{Cl}$ & 0.009 & 0.008 & 0.018 & 0.007 \\
\hline $\mathrm{F}$ & 0.006 & $0.006^{(\mathrm{d})}$ & 0.010 & $0.012^{(\mathrm{d})}$ \\
\hline $\mathrm{SO}_{4}$ & 0.018 & 0.017 & 0.004 & 0.030 \\
\hline $\mathrm{PO}_{4}$ & 0.010 & $0.010^{(\mathrm{d})}$ & 0.005 & $0.010^{(\mathrm{d})}$ \\
\hline $\mathrm{NO}_{2}$ & 0.085 & 0.113 & 0.194 & 0.098 \\
\hline $\mathrm{NO}_{3}$ & 0.502 & 0.324 & 0.287 & 0.367 \\
\hline $\mathrm{CO}_{3}$ & 0.095 & 0.055 & 0.040 & 0.035 \\
\hline $\mathrm{TOC}$ Total & 0.057 & 0.015 & 0.021 & 0.007 \\
\hline Free OH & 0.097 & 0.312 & 0.293 & 0.306 \\
\hline$(\mathrm{a})$ & & &
\end{tabular}

(a) SST = single-shell tank

(b) HTWOS = Hanford Tank Waste Operations Simulator

(c) After charge balancing.

(d) Concentration of $\mathrm{F}$ and $\mathrm{PO}_{4}{ }^{3-}$ reduced from HTWOS values because of solids formation observed in preliminary simulants.

“_” = not included

Table B.4. Final Spike Levels for Hazardous Constituents and Radionuclides in Simulants for Cast Stone Screening Tests (Westsik et al. 2013)

\begin{tabular}{|c|c|c|c|}
\hline \multicolumn{3}{|c|}{ HTWOS } & \multirow{3}{*}{$\begin{array}{c}\text { Other } \\
\text { Considerations }\end{array}$} \\
\hline & Overall & HTWOS & \\
\hline Waste Constituent & Average & Maximum & \\
\hline RCRA Metals and UHCs $^{(\mathrm{d})}$ & moles/mole $\mathrm{Na}$ & moles/mole $\mathrm{Na}$ & moles/mole $\mathrm{Na}$ \\
\hline $\mathrm{Cd}$ & $2.78 \mathrm{E}-06$ & $3.19 \mathrm{E}-05$ & - \\
\hline $\mathrm{Cr}$ & $2.42 \mathrm{E}-03$ & $9.99 \mathrm{E}-03$ & $4.30 \mathrm{E}-03^{(\mathrm{a})}$ \\
\hline $\mathrm{Pb}$ & $1.16 \mathrm{E}-05$ & $5.13 \mathrm{E}-05$ & - \\
\hline $\mathrm{Ni}$ & $6.41 \mathrm{E}-05$ & $6.61 \mathrm{E}-04$ & - \\
\hline Radionuclides & $\mathrm{Ci} / \mathrm{mole} \mathrm{Na}$ & $\mathrm{Ci} /$ mole $\mathrm{Na}$ & $\mathrm{Ci} / \mathrm{mole} \mathrm{Na}$ \\
\hline${ }^{99} \mathrm{Tc}$ & $1.13 \mathrm{E}-05$ & $4.13 \mathrm{E}-05$ & - \\
\hline${ }^{99} \mathrm{Tc}^{(\mathrm{c})}$ & $(6.65 \mathrm{E}+02 \mu \mathrm{g} / \mathrm{mole} \mathrm{Na})$ & $(2.43 \mathrm{E}+03 \mu \mathrm{g} / \mathrm{mole} \mathrm{Na})$ & \\
\hline${ }^{129} \mathrm{I}$ & $1.44 \mathrm{E}-08$ & $8.01 \mathrm{E}-08$ & $3.54 \mathrm{E}-06^{(\mathrm{b})}$ \\
\hline${ }^{127} \mathrm{I}$ (stable) ${ }^{(\mathrm{c})}$ & $(8.14 \mathrm{E}+01 \mu \mathrm{g} /$ mole $\mathrm{Na})$ & $(4.53 \mathrm{E}+02 \mu \mathrm{g} / \mathrm{mole} \mathrm{Na})$ & $(2.00 \mathrm{E}+04 \mu \mathrm{g} / \mathrm{mole} \mathrm{Na})$ \\
\hline $232+233+234+235+236+238 \mathrm{U}$ & $1.59 \mathrm{E}-08$ & $5.63 \mathrm{E}-08$ & - \\
\hline Natural or depleted $\mathrm{U}^{(\mathrm{c})}$ & - & $(3.56+04 \mu \mathrm{g} / \mathrm{mole} \mathrm{Na})$ & - \\
\hline $\begin{array}{l}\text { (a) Cr concentration adjuste } \\
\text { (b) Iodine concentration inc } \\
\text { Iodine added as nonradi } \\
\text { (c) These COCs were addec } \\
\text { (d) UHCs = underlying haz }\end{array}$ & $\begin{array}{l}\text { ased on review of best } b \\
\text { ased to address possible } d \\
\text { ctive }{ }^{127} \mathrm{I} \text {. } \\
\text { simulants based on mas } \\
\text { lous constituents }\end{array}$ & $\begin{array}{l}\text { sis inventory and previou } \\
\text { tection limits issues in wo } \\
\text { (as shown). }\end{array}$ & $\begin{array}{l}\text { simulant work. } \\
\text { ste form leach tests. }\end{array}$ \\
\hline
\end{tabular}


Table B.5. WTP Secondary Waste Simulant Composition (Mattigod et al. 2011)

\begin{tabular}{|c|c|c|c|c|c|c|c|}
\hline Element & $\begin{array}{l}\text { Baseline }^{(a)} \\
\text { (Moles/L) }\end{array}$ & Chemical Formula & CAS \# $\#^{(b)}$ & $\begin{array}{c}\text { Formula } \\
\text { Wt (g) }\end{array}$ & $\begin{array}{c}\text { Chemical Mass } \\
(\mathrm{g} / \mathrm{L})\end{array}$ & $\begin{array}{c}\text { Chemical Mass } \\
(\mathrm{g} / \mathrm{L})\end{array}$ & $\begin{array}{c}\text { Chemical Mass } \\
(\mathrm{g} / \mathrm{L})\end{array}$ \\
\hline Na molarity & 1.00 & -- & -- & -- & 2.00 & 4.00 & 6.00 \\
\hline $\mathrm{Ag}$ & $6.27 \mathrm{E}-06$ & $\mathrm{AgNO}_{3}$ & 7761-88-8 & 169.87 & 0.002 & 0.004 & 0.006 \\
\hline $\mathrm{Al}$ & 9.39E-02 & gibbsite & 21645-51-2 & 78.00 & 14.648 & 29.297 & 43.945 \\
\hline As & $3.48 \mathrm{E}-05$ & $\mathrm{Na}_{2} \mathrm{HAsO}_{4} \cdot 7 \mathrm{H}_{2} \mathrm{O}$ & $10048-95-0$ & 312.01 & 0.022 & 0.043 & 0.065 \\
\hline $\mathrm{Cd}$ & $1.57 \mathrm{E}-06$ & $\mathrm{Cd}\left(\mathrm{NO}_{3}\right)_{2} \cdot 4 \mathrm{H}_{2} \mathrm{O}$ & 10022-68-1 & 308.48 & 0.001 & 0.002 & 0.003 \\
\hline Cl- & 2.25E-02 & $\mathrm{NaCl}$ & $7647-14-5$ & 58.44 & 2.630 & 5.260 & 7.889 \\
\hline $\mathrm{CO}_{3}^{-2}$ & $2.28 \mathrm{E}-02$ & $\mathrm{Na}_{2} \mathrm{CO}_{3}$ & $497-19-8$ & 105.99 & 4.833 & 9.666 & 14.499 \\
\hline $\mathrm{Cr}$ & 2.03E-04 & $\mathrm{Na}_{2} \mathrm{Cr}_{2} \mathrm{O}_{7} \cdot 2 \mathrm{H}_{2} \mathrm{O}$ & 7789-12-0 & 298.00 & 0.121 & 0.121 & 0.363 \\
\hline $\mathrm{F}$ & 5.57E-04 & $\mathrm{NaF}$ & $7681-49-4$ & 41.99 & 0.047 & 0.094 & 0.140 \\
\hline $\mathrm{Hg}$ & 1.13E-05 & $\mathrm{Hg}\left(\mathrm{NO}_{3}\right)_{2} \cdot \mathrm{H}_{2} \mathrm{O}$ & 7783-34-8 & 342.62 & 0.008 & 0.015 & 0.023 \\
\hline I & 4.62E-06 & $\mathrm{NaI}$ & $7681-82-5$ & 149.89 & 0.001 & 0.003 & 0.004 \\
\hline $\mathrm{K}$ & 5.82E-04 & $\mathrm{KNO}_{3}$ & 7757-79-1 & 101.10 & 0.118 & 0.235 & 0.353 \\
\hline $\mathrm{NO}_{3}^{-}$ & $3.28 \mathrm{E}-01$ & $\mathrm{NaNO}_{3}$ & 7631-99-4 & 84.99 & 55.753 & 111.507 & 167.260 \\
\hline $\mathrm{NO}_{2}^{-}$ & $1.20 \mathrm{E}-02$ & $\mathrm{NaNO}_{2}$ & $7632-00-0$ & 69.00 & 1.656 & 3.312 & 4.968 \\
\hline $\mathrm{OH}$ & 3.98E-01 & $\mathrm{NaOH}$ & 1310-73-2 & 40.00 & 31.840 & 63.680 & 95.520 \\
\hline $\mathrm{Pb}$ & 8.99E-06 & $\mathrm{Pb}\left(\mathrm{NO}_{3}\right)_{2}$ & $10099-74-8$ & 331.23 & 0.006 & 0.012 & 0.018 \\
\hline $\mathrm{PO}_{4}^{3-}$ & 6.87E-03 & $\mathrm{Na}_{3} \mathrm{PO}_{4} \cdot 12 \mathrm{H}_{2} \mathrm{O}$ & 7558-80-7 & 380.13 & 5.223 & 10.446 & 15.669 \\
\hline $\mathrm{Re}$ & $1.81 \mathrm{E}-05$ & $\mathrm{NaReO}_{4}$ & 13472-33-8 & 273.19 & 0.010 & 0.02 & 0.030 \\
\hline $\mathrm{Si}$ & 1.88E-03 & $\mathrm{Na}_{2} \mathrm{SiO}_{3} \cdot 9 \mathrm{H}_{2} \mathrm{O}$ & $13517-24-3$ & 284.20 & 1.069 & 2.137 & 3.206 \\
\hline $\mathrm{SO}_{4}^{2-}$ & $4.41 \mathrm{E}-03$ & $\mathrm{Na}_{2} \mathrm{SO}_{4}$ & 7757-82-6 & 142.04 & 1.253 & 2.506 & 3.758 \\
\hline${ }^{99} \mathrm{Tc}$ & $3.05 \mathrm{E}-05^{(\mathrm{c})}$ & ${ }^{99} \mathrm{Tc}$ & -- & 99.00 & $0.0001^{\mathrm{c}}$ & $0.0002^{\mathrm{c}}$ & $0.0003^{\mathrm{C}}$ \\
\hline $\mathrm{TOC}^{(\mathrm{d})}$ & 7.98E-02 & $\mathrm{Na}_{2} \mathrm{C}_{2} \mathrm{O}_{4}$ & $62-76-0$ & 134.00 & 21.386 & 42.773 & 64.159 \\
\hline $\mathrm{TOC}^{(\mathrm{d})}$ & $1.41 \mathrm{E}-02$ & $\mathrm{C}_{2} \mathrm{O}_{4} \cdot 2 \mathrm{H}_{2} \mathrm{O}$ & 6153-56-6 & 126.07 & 3.555 & 7.110 & 10.666 \\
\hline \multicolumn{8}{|c|}{$\begin{array}{l}\text { (b) Chemical Abstracts Service Registry Number } \\
\text { (c) } \mathrm{Ci} / \mathrm{L} \\
\text { (d) As Oxalate }\end{array}$} \\
\hline
\end{tabular}


Appendix C

\section{Mineral Compositions of LSW Grouts}





\section{Appendix C}

\section{Mineral Compositions of LSW Grouts}

Table C.1. Moisture Content, Dry Solids Fraction, and X-Ray Diffraction (XRD) Analysis for Mineral Content (Um et al. 2016)

\begin{tabular}{cccccccccc}
\hline \multirow{2}{*}{$\begin{array}{c}\text { Test } \\
\text { Batch \# }\end{array}$} & \multirow{2}{*}{$\begin{array}{c}\text { MC } \\
\text { (\%) }\end{array}$} & Dry Solids & Fraction & \multicolumn{7}{c}{ XRD Analysis (wt\%) } & Etringite & Portlandite & Calcite & Larnite & Hydrocalumite & Quartz & Amorphous \\
\hline 1 & 27.13 & 0.729 & 12 & 11 & 9.0 & 4.2 & - & 3.0 & 61 \\
2 & 25.03 & 0.750 & 9.8 & 14 & 6.9 & 4.5 & 6.1 & - & 58 \\
3 & 25.14 & 0.749 & 14 & 11 & 6.8 & 4.4 & - & - & 64 \\
4 & 30.63 & 0.694 & 9.3 & 12 & 6.8 & 4.9 & - & - & 66 \\
5 & 29.42 & 0.706 & 9.4 & 12 & 3.3 & 6.4 & 5.4 & - & 63 \\
6 & 29.74 & 0.703 & 17 & 9.7 & 5.4 & 4.5 & - & - & 63 \\
7 & 25.48 & 0.745 & 9.7 & 15 & 7.2 & 4.9 & 5.5 & 0.3 & 58 \\
8 & 29.79 & 0.702 & 16 & 10 & 9.9 & 5.1 & - & 0.9 & 58 \\
9 & 27.89 & 0.721 & 11 & 9.1 & 5.8 & 2.4 & - & 0.4 & 71 \\
10 & 27.52 & 0.725 & 16 & 8.1 & 6.8 & 3.7 & - & 0.6 & 65 \\
11 & 30.44 & 0.696 & 15 & - & 4.5 & 4.1 & - & 2.0 & 75 \\
12 & 29.63 & 0.704 & 14 & - & 3.7 & 2.4 & - & 1.5 & 78 \\
13 & 26.64 & 0.734 & 12 & - & 4.2 & 2.0 & - & 4.1 & 78 \\
14 & 25.77 & 0.742 & 8.9 & 14 & 8.6 & 4.6 & 2.8 & 1.3 & 60 \\
15 & 24.99 & 0.750 & 19 & 8.9 & 5.7 & 6.5 & - & - & 60 \\
16 & 25.43 & 0.746 & 16 & 11 & 4.6 & 4.0 & - & 0.4 & 63 \\
17 & 26.66 & 0.733 & 13 & 7.9 & 4.1 & 3.9 & - & 0.6 & 70 \\
18 & 26.46 & 0.735 & 13 & 7.8 & 4.0 & 4.1 & - & 1.2 & 70 \\
$19^{(\mathrm{c})}$ & 26.21 & 0.738 & 13 & 9.5 & - & 5.3 & - & - & 72 \\
$20^{(\mathrm{c})}$ & 29.74 & 0.703 & 15 & 8.0 & - & 4.4 & - & - & 73 \\
$21^{(\mathrm{c})}$ & 31.21 & 0.688 & 12 & - & - & 3.7 & - & 1.8 & 82 \\
\hline
\end{tabular}

(a) $\mathrm{MC}=$ moisture content

(b) chemical formulas of minerals: ettringite $\left[\mathrm{Ca}_{6} \mathrm{Al}_{2}\left(\mathrm{SO}_{4}\right)_{3}(\mathrm{OH})_{12} \cdot 26 \mathrm{H}_{2} \mathrm{O}\right]$, portlandite $\left[\mathrm{Ca}(\mathrm{OH})_{2}\right]$, calcite $\left[\mathrm{CaCl}_{2}\right]$, larnite $\left[\mathrm{Ca}_{2} \mathrm{SiO}_{4}\right]$, hydrocalumite $\left.\left[\mathrm{Ca}_{4} \mathrm{Al}_{2}(\mathrm{OH})_{12}(\mathrm{OH})_{2} \cdot 6 \mathrm{H}_{2} \mathrm{O}\right)\right]$, and quartz $\left[\mathrm{SiO}_{2}\right]$

(c) non-radiological grout monoliths (T19, T20, and T21) 

Appendix D

\section{EPA 1313 Results for LSW Grouts}





\section{Appendix D}

\section{EPA 1313 Results for LSW Grouts}

Table D.1. Measured pH, EC, $E_{h}$, and ${ }^{99}$ Tc in Solution from EPA Method 1313 Leaching Test on LSW Grouts (Um et al. 2016)

\begin{tabular}{|c|c|c|c|c|}
\hline Monolith \# & $\mathrm{pH}$ & $\begin{array}{c}\mathrm{EC} \\
(\mathrm{mS} / \mathrm{cm})\end{array}$ & $\begin{array}{c}E_{h} \\
(\mathrm{mV})\end{array}$ & $\begin{array}{c}{ }^{99} \text { Tc concentration } \\
(\mu \mathrm{g} / \mathrm{g}) \\
\end{array}$ \\
\hline \multirow{9}{*}{ T3 } & 12.6 & 16.9 & 153.8 & 0.988 \\
\hline & 12.1 & 24.9 & 185 & 0.778 \\
\hline & 10.7 & 50.1 & 263.2 & 1.01 \\
\hline & 9.33 & 74.1 & 350 & 0.571 \\
\hline & 9.12 & 76.2 & 358 & 0.65 \\
\hline & 8.5 & 80.3 & 369 & 0.502 \\
\hline & 7.4 & 84.2 & 414 & 0.293 \\
\hline & 5.32 & 94.5 & 327 & 0.322 \\
\hline & 3.4 & 100 & 526 & 0.437 \\
\hline \multirow{9}{*}{ T6 } & 12.4 & 18.2 & 148.2 & 0.951 \\
\hline & 12.1 & 25.5 & 176.4 & 0.931 \\
\hline & 10.4 & 51.3 & 252.6 & 0.873 \\
\hline & 9.77 & 66.1 & 287.6 & 0.715 \\
\hline & 8.9 & 75.1 & 326 & 0.939 \\
\hline & 8.46 & 77.4 & 339 & 1.08 \\
\hline & 6.57 & 85.8 & 402 & 0.863 \\
\hline & 4.87 & 92.4 & 374 & 0.818 \\
\hline & 3.76 & 95.8 & 481 & 0.897 \\
\hline \multirow{9}{*}{ T11 } & 12.6 & 27.7 & 123.6 & 2.44 \\
\hline & 12.3 & 10.4 & 147.2 & 1.78 \\
\hline & 9.89 & 27 & 270.7 & 2.22 \\
\hline & 9.22 & 38.7 & 317 & 2.18 \\
\hline & 8.72 & 44.4 & 340 & 2.18 \\
\hline & 7.55 & 52.7 & 393 & 1.88 \\
\hline & 6.49 & 60.3 & 388 & 1.98 \\
\hline & 3.9 & 74.1 & 455 & 1.42 \\
\hline & 2.83 & 92.8 & 593 & 1.65 \\
\hline
\end{tabular}


Table D.2. Concentrations of Major Cations in Filtrate Collected for EPA Method 1313 Leaching Test on LSW Grouts (Um et al 2016)

\begin{tabular}{|c|c|c|c|c|c|c|}
\hline Monolith \# & $\mathrm{pH}$ & $\begin{array}{c}\mathrm{Na} \\
(\mu \mathrm{g} / \mathrm{L})\end{array}$ & $\begin{array}{c}\mathrm{K} \\
(\mu \mathrm{g} / \mathrm{L})\end{array}$ & $\begin{array}{c}\mathrm{Si} \\
(\mu \mathrm{g} / \mathrm{L})\end{array}$ & $\begin{array}{c}\mathrm{S} \\
(\mu \mathrm{g} / \mathrm{L})\end{array}$ & $\begin{array}{c}\mathrm{Fe} \\
(\mu \mathrm{g} / \mathrm{L})\end{array}$ \\
\hline \multirow{9}{*}{ T3 } & 12.6 & $1.55 \mathrm{E}+06$ & $2.04 \mathrm{E}+05$ & $\mathrm{ND}^{(\mathrm{a})}$ & $1.29 \mathrm{E}+04$ & ND \\
\hline & 12.1 & $3.79 E+05$ & $4.06 \mathrm{E}+04$ & $2.14 \mathrm{E}+03$ & $1.15 \mathrm{E}+04$ & ND \\
\hline & 10.7 & $2.46 \mathrm{E}+05$ & $3.14 \mathrm{E}+04$ & $3.20 \mathrm{E}+03$ & $2.50 \mathrm{E}+04$ & ND \\
\hline & 9.33 & $2.54 \mathrm{E}+05$ & $3.81 \mathrm{E}+04$ & $3.22 \mathrm{E}+03$ & $1.52 \mathrm{E}+05$ & ND \\
\hline & 9.12 & $4.43 E+05$ & $2.85 \mathrm{E}+04$ & $2.86 \mathrm{E}+03$ & $1.26 \mathrm{E}+05$ & ND \\
\hline & 8.5 & $3.66 \mathrm{E}+05$ & $2.91 \mathrm{E}+04$ & $5.62 \mathrm{E}+03$ & $2.39 \mathrm{E}+05$ & ND \\
\hline & 7.4 & $2.11 \mathrm{E}+05$ & $1.84 \mathrm{E}+04$ & $1.94 \mathrm{E}+03$ & $1.40 \mathrm{E}+05$ & ND \\
\hline & 5.32 & $4.49 \mathrm{E}+05$ & $4.68 \mathrm{E}+04$ & $1.32 \mathrm{E}+04$ & $3.35 E+05$ & $1.43 E+05$ \\
\hline & 3.4 & $2.10 \mathrm{E}+06$ & $2.67 \mathrm{E}+05$ & $4.98 \mathrm{E}+04$ & $5.90 \mathrm{E}+05$ & $3.93 \mathrm{E}+05$ \\
\hline \multirow{9}{*}{ T6 } & 12.4 & $1.83 \mathrm{E}+06$ & $1.78 \mathrm{E}+05$ & ND & $1.44 \mathrm{E}+04$ & ND \\
\hline & 12.1 & $7.30 \mathrm{E}+05$ & $7.42 \mathrm{E}+04$ & ND & $3.89 \mathrm{E}+04$ & ND \\
\hline & 10.4 & $3.80 \mathrm{E}+05$ & $3.36 \mathrm{E}+04$ & $3.13 E+03$ & $1.09 \mathrm{E}+05$ & ND \\
\hline & 9.77 & $2.67 \mathrm{E}+05$ & $3.19 \mathrm{E}+04$ & $3.91 E+03$ & $1.92 \mathrm{E}+05$ & ND \\
\hline & 8.9 & $2.02 E+05$ & $1.73 \mathrm{E}+04$ & $1.84 \mathrm{E}+03$ & $1.41 \mathrm{E}+05$ & ND \\
\hline & 8.46 & $3.04 \mathrm{E}+05$ & $3.00 \mathrm{E}+04$ & $1.28 \mathrm{E}+03$ & $1.25 \mathrm{E}+05$ & ND \\
\hline & 6.57 & $2.21 \mathrm{E}+06$ & $1.78 \mathrm{E}+05$ & $7.01 \mathrm{E}+03$ & $5.71 \mathrm{E}+05$ & ND \\
\hline & 4.87 & $2.25 E+06$ & $2.15 \mathrm{E}+05$ & $1.93 \mathrm{E}+04$ & $5.96 \mathrm{E}+05$ & $2.44 \mathrm{E}+05$ \\
\hline & 3.76 & $2.25 E+06$ & $2.33 \mathrm{E}+05$ & $3.84 \mathrm{E}+04$ & $5.85 E+05$ & $3.11 E+05$ \\
\hline \multirow{9}{*}{$\mathrm{T} 11$} & 12.6 & $1.78 \mathrm{E}+06$ & $\mathrm{NA}^{(\mathrm{b})}$ & $2.35 \mathrm{E}+04$ & $3.01 \mathrm{E}+05$ & $\mathrm{NR}^{(\mathrm{c})}$ \\
\hline & 12.3 & $1.60 \mathrm{E}+06$ & $1.17 \mathrm{E}+05$ & $1.42 \mathrm{E}+04$ & $2.55 \mathrm{E}+05$ & NR \\
\hline & 9.89 & $1.32 \mathrm{E}+06$ & $9.65 \mathrm{E}+04$ & $6.43 E+03$ & $8.56 \mathrm{E}+05$ & ND \\
\hline & 9.22 & $2.13 E+06$ & $1.27 \mathrm{E}+05$ & $4.19 \mathrm{E}+03$ & $4.76 \mathrm{E}+05$ & ND \\
\hline & 8.72 & $2.22 \mathrm{E}+06$ & $1.34 \mathrm{E}+05$ & $3.37 E+03$ & $4.90 \mathrm{E}+05$ & ND \\
\hline & 7.55 & $2.25 E+06$ & $1.41 \mathrm{E}+05$ & $4.67 \mathrm{E}+03$ & $5.08 \mathrm{E}+05$ & ND \\
\hline & 6.49 & $2.30 \mathrm{E}+06$ & $1.62 \mathrm{E}+05$ & $1.07 \mathrm{E}+04$ & $5.05 \mathrm{E}+05$ & ND \\
\hline & 3.9 & $2.38 \mathrm{E}+06$ & $2.27 \mathrm{E}+05$ & $5.82 E+04$ & $5.08 \mathrm{E}+05$ & $2.94 \mathrm{E}+05$ \\
\hline & 2.83 & $2.91 \mathrm{E}+06$ & $3.48 \mathrm{E}+05$ & $1.01 \mathrm{E}+05$ & $6.67 \mathrm{E}+05$ & $6.03 E+05$ \\
\hline
\end{tabular}

(a) ND indicates "not detected," sample concentration below quantification level for Si $(<548 \mu \mathrm{g} / \mathrm{L})$ and $\mathrm{Fe}(<100$ $\mu \mathrm{g} / \mathrm{L})$.

(b) NA indicates $\mathrm{K}$ for T11, $\mathrm{pH} 12.6$, is not applicable; $\mathrm{KOH}$ was added to this sample to adjust the $\mathrm{pH}$.

(c) NR = not reportable (due to high iron in blanks) 
Appendix E

\section{Moisture Retention Curves for Selected LSW Grouts}





\section{Appendix E}

\section{Moisture Retention Curves for Selected LSW Grouts}

Figure E.1 through Figure E.3 provide the characteristic curves for Hanford secondary waste. For comparison purposes, the characteristic curves for saltstone are included in these figures.

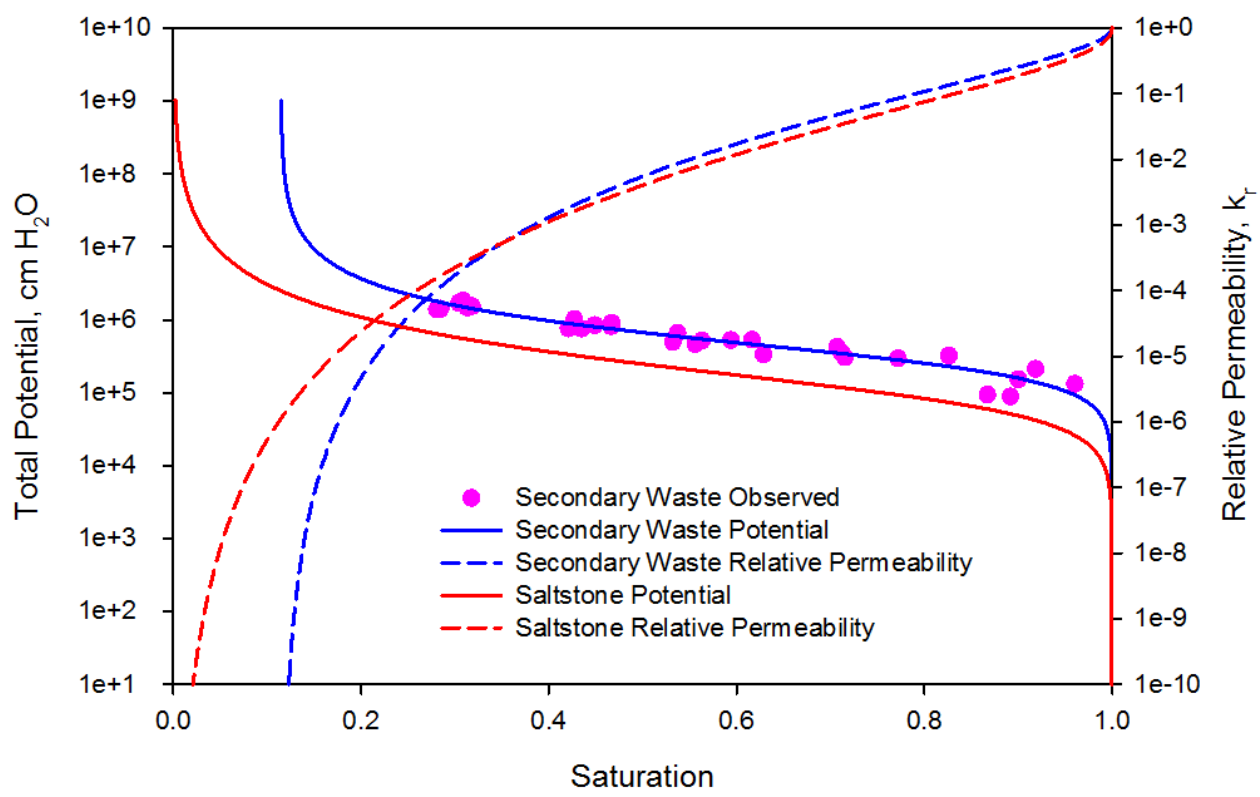

Figure E.1. Characteristic Curves for Mixes 3, 6, and 11 Combined - Drying

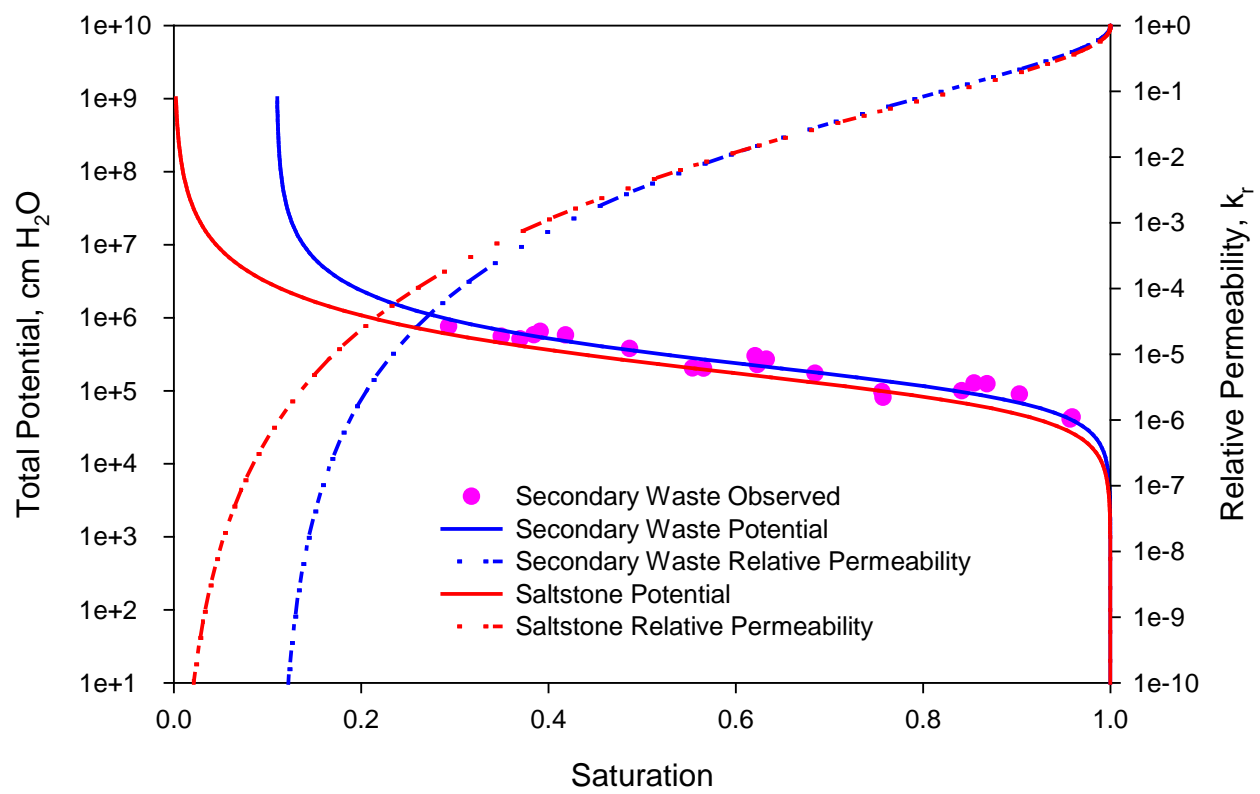

Figure E.2. Characteristic Curves for Mixes 3, 6, and 11 Combined - Wetting 


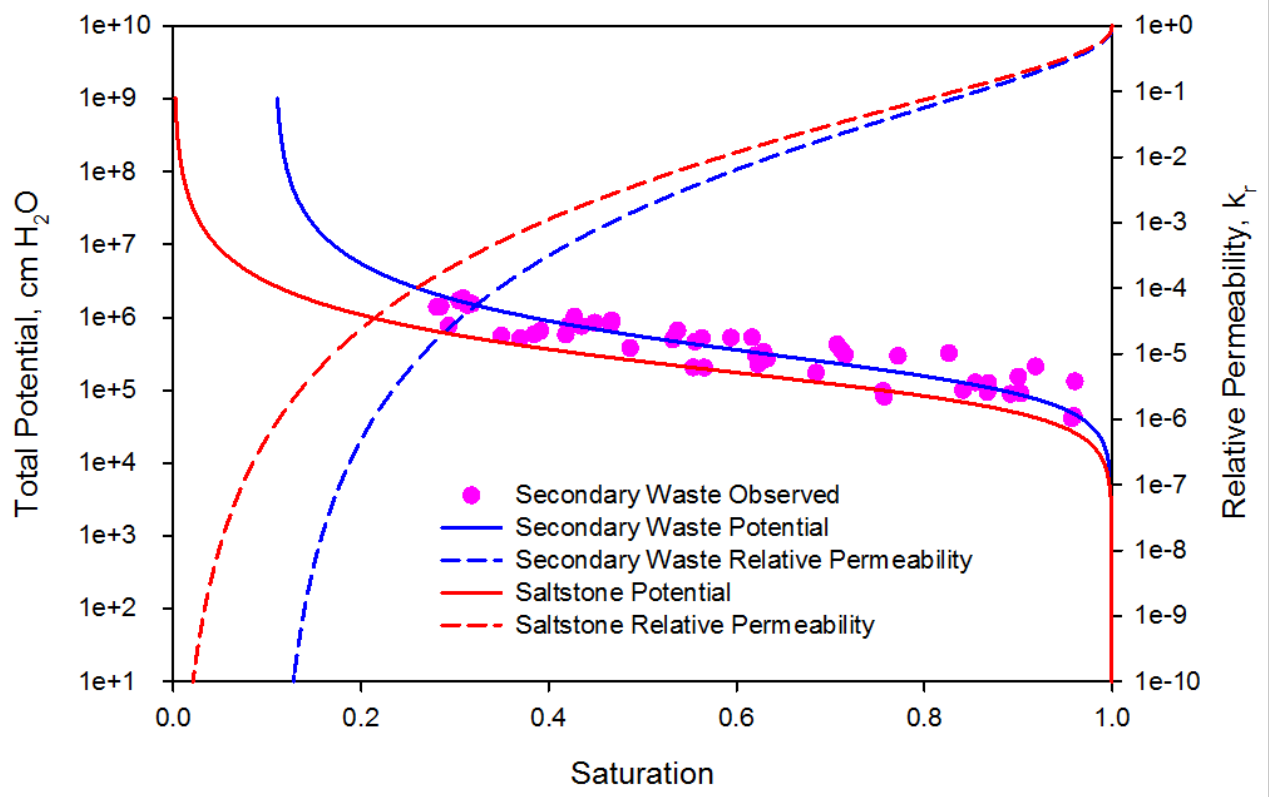

Figure E.3. Characteristic Curves for Mixes 3, 6, and 11 Combined - Drying and Wetting. 
PNNL-25194

RPT-SWCS-006, Rev. 0

\section{Distribution}

U.S. Department of Energy Office of River Protection

GL Pyles

Washington River Protection Solutions

PA Cavanah

KP Lee

DJ Swanberg

WRPS Documents - TOCVND@rl.gov

Savannah River National Laboratory

AD Cozzi

G Flach

KM Fox

The Catholic University of America

Vitreous State Laboratory

IL Pegg

INTERA

R Andrews

M Apted

R Arthur
Pacific Northwest National Laboratory

MR Asmussen

DH Bacon

VL Freedman

JJ Neeway

NP Qafoku

ML Rockhold

RJ Serne

GL Smith

W Um

JH Westsik, Jr.

SB Yabusaki

Project File

Information Release (pdf)

*All distribution will be made electronically.

Dist. 1 




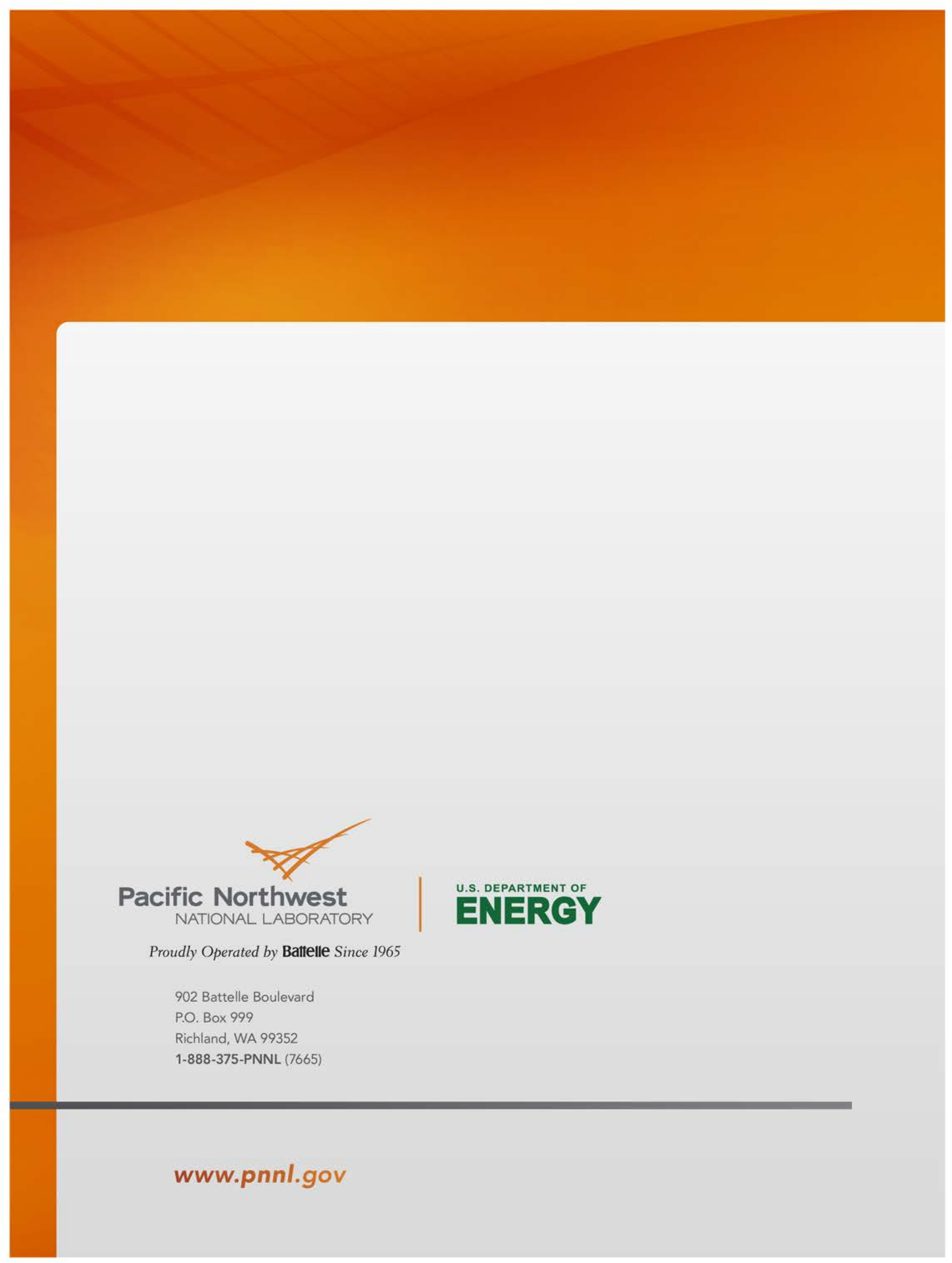

